SILAGEM DE CAPIM-ELEFANTE (Pennisetum purpureum Schum.), EM TRÊS ESTÁDIOS DE MATURIDADE, SUBMETIDO AO EMURCHECIMENTO

\author{
JOSÉ NARCISO SOBRINHO \\ Licenciado em Ciências Agrícolas
}

Orientador: Prof. Dr. Herbert Barbosa de Mattos

Dissertação apresentada à Escola Superior de Agricultura "Luiz de Queiroz", Universidade de São Paulo, para obtenção do título de Mestre em Agronomia, Área de Concentração: Ciência Animal e Pastagens.

\author{
PIRACICABA \\ Estado de São Paulo - Brasil \\ Abril - 1998
}


Dados Internacionais de Catalogacão na Publicação (CIP) DIVISÃO DE BIBLIOTECA E DOCUMENTAÇĀO - Campus "Luiz de Queiroz"/USP

\section{Narciso Sobrinho, José}

Silagem de capim-elefante (Pennisetum purpureum Schum.), em três estádios de maturidade, submetido ao emurchecimento / José Narciso Sobrinho. - - Piracicaba, 1998.

$105 \mathrm{p}$.

Dissertação (mestrado) - - Escola Superior de Agricultura Luiz de Queiroz, 1998. Bibliografia.

1. Emurchecimento 2. Matéria seca 3. Maturidade 4. Qualidade 5. Silagem de capim-elefance 6 . Valor nutritivo I. Título

CDD 636.08552 
À minha esposa Vilani e aos meus filhos Mêndel, José e Isabelle, pela compreensão, amor e carinho oferecidos durante a realização deste trabalho,

DEDICO. 
À minha mãe Maria Luisa e a todos da minha família que vibraram e torceram com a realização deste trabalho.

Ao meu pai Aurino "in memoriam", pelo exemplo de vida que deixou para os filhos, 


\section{AGRADECIMENTOS}

A Deus, por me iluminar em todos os momentos da minha

vida.

Ao Banco do Nordeste do Brasil S.A., pela minha liberação para realização deste curso.

Ao Prof. Dr. Herbert Barbosa de Mattos, pela orientação, apoio e ensinamentos, mesmo já tendo decorrido um ano do início do curso.

- Ao Pesquisador Dr. João Batista de Andrade, pela colaboração na orientação, ensinamentos, incentivo, amizade e apoio durante todas as etapas do trabalho.

Ao Prof. Dr. Celso Boin, pela orientação inicial.

Ao Instituto de Zootecnia do Estado de São Paulo, particularmente ao Dr. Paulo Bardauil e Dr. Vanderley Benedito de Oliveira, pela aceitação da realização deste trabalho de pesquisa nas Estações Experimentais de Brotas e Nova Odessa.

À Fundação de Amparo à Pesquisa do Estado de São Paulo (FAPESP), pelo financiamento do projeto de pesquisa.

A Coordenação de Aperfeiçoamento de Pessoal de Nivel Superior (CAPES), pelo aporte de recursos financeiros concedido.

Ao Prof. Dr. Carlos Pedreira, pelo apoio e colaboração no summary.

Aos professores Dr. Sila Carneiro, Dr. Umberto Packer, Dr. Valdomiro Miyada e Dr. José Eurico, pela atenção e apoio durante o curso.

À Escola Superior de Agricultura "Luiz de Queiroz", pela oportunidade deste treinamento.

. Ao colega Vicente Paulo Martello, pela amizade, ajuda e apoio durante a fase de campo. 
Ao Sr. Antonio Martello e Sra. Thereza Martello, pelo acolhimento na cidade de Brotas-SP, durante a primeira fase do trabalho.

Ao funcionário Nilson do Nascimento, do Instituto de Zootecnia (IZ), pela ajuda na fase de consumo e digestibilidade.

. Ao Pesquisador Evaldo Ferrari Júnior, pelo convívio no IZ.

. Ao Dr. Braun e aos funcionários Carmem, Neuza e Sérgio, do Laboratório de Bromatologia do IZ, pela realização de parte das análises.

Às funcionárias do IZ, Verônica, Cristina, Edna e Lia, pela atenção e amizade.

Às colegas Michelle e Moema, pelo apoio e amizade durante a realização deste trabalho.

Aos colegas Jailson e Osvaldo, pela amizade e convívio durante o curso.

Ao colega Marcos Martinez, pela amizade, convivio e acolhimento na cidade de Piracicaba.

A todos aqueles que, de alguma forma, contribuiram com a realização deste trabalho.

A todos os colegas do Curso de Ciência Animal e Pastagens da ESALQ, pelo convivio durante a realização do mestrado. 


\section{SUMÁRIO}

Página

LISTA DE TABELAS

vii

LISTA DE FIGURAS ............... .....................................................

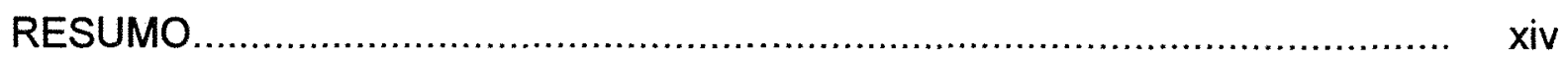

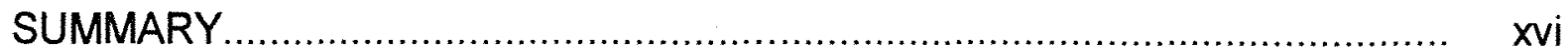

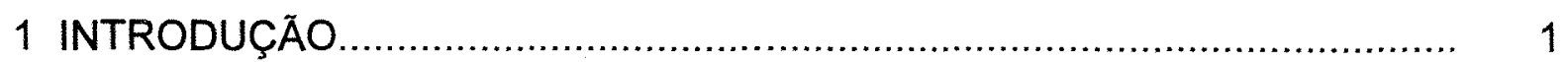

2 REVISÃO DE LITERATURA ......................................................... 3

2.1 capim-elefante e seu potencial forrageiro para ensilagem................... 3

2.2 Qualidade e valor nutritivo da silagem............................................. 12

3 MATERIAL E MÉTODOS.............................................................. 17

3.1. Avaliação da produção do capim-elefante........................................ 17

3.2. Determinação da composição química das forragens, da qualidade e do valor nutritivo das silagens.......................................................... 18

3.3 Análises laboratoriais.................................................................. 22

4 RESULTADOS E DISCUSSÃO ......................................................... 23

4.1 Produção do capim-elefante.......................................................... 23

4.1.1 Produção de matéria seca............................................................. 23

4.1.2 Porcentagens de haste, lâmina e material morto............................. 25

4.2 Efeito do emurchecimento na composição das forragens utilizadas......... 27

4.2.1 Porcentagem de matéria seca..................................................... 27

4.2.2 Porcentagem de proteína bruta.................................................. 31

4.2.3 Porcentagem de fibra em detergente neutro................................ 34

4.2.4 Porcentagem de carboidratos solúveis........................................ 37

4.2.5 Poder tampão das forragens................................................ 41

4.3 Qualidade das silagens........................................................... 44

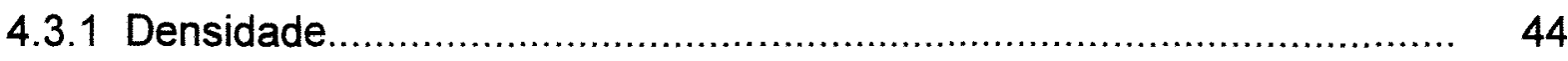


4.3.2 Porcentagem de matéria seca.................................................. 46

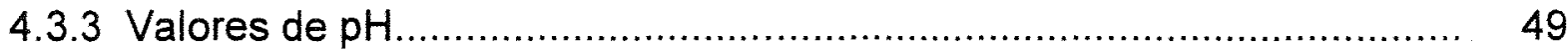

4.3.4 Porcentagem de ácido láctico ................................................... 52

4.3.5 Porcentagem de ácido acético................................................ 55

4.3.6 Porcentagem de ácido propiônico .................................................. 58

4.3.7 Porcentagem de ácido butírico.................................................... 60

4.3.8 Porcentagem de nitrogênio amoniacal em relação ao nitrogênio total... 61

4.4 Consumo e digestibilidade das silagens........................................... 64

4.4.1. Ingestão de matéria seca das silagens............................................ 64

4.4.2 Coeficiente de digestibilidade aparente da matéria seca.. $\quad$................ 67

4.4.3 Coeficiente de digestibilidade aparente da proteina bruta................... 70

4.4.4 Coeficiente de digestibilidade aparente da fibra bruta...................... 72

4.4.5 Coeficiente de digestibilidade do extrato etéreo................................ 75

4.4.6 Coeficiente de digestibilidade dos extrativos não nitrogenados............ 77

4.4.7. Coeficiente de digestibilidade da fibra em detergente neutro.............. 80

4.4.8 Porcentagem de nutrientes digestíveis totais................................ 82

4.4.9 Ingestão de nutrientes digestíveis totais....................................... 85

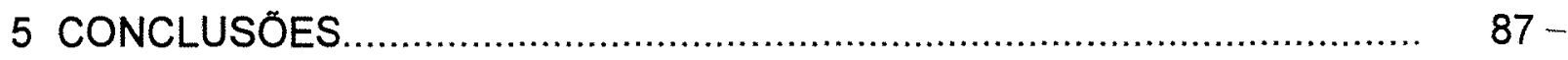

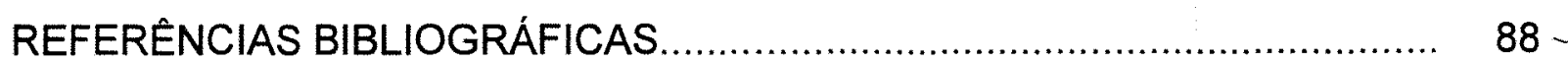




\section{LISTA DE TABELAS}

Página

1 Esquema de análise de variância das características determinadas nas silagens

2 Produção média de matéria seca, em $\mathrm{kg} / \mathrm{ha}$, do capim-elefante, cultivar Guaçu, aos 56, 70 e 84 dias de desenvolvimento.

3 Porcentagens de haste, lâmina e material morto da forragem do capimelefante, cultivar Guaçu, aos 56,70 e 84 dias de desenvolvimento.......

4 Porcentagem de matéria seca das forragens fresca e emurchecidas (inteira e triturada) do capim-elefante, cultivar Guaçu, aos 56, 70 e 84 dias de desenvolvimento.

5 Porcentagem de proteína bruta das forragens fresca e emurchecidas (inteira e triturada) do capim-elefante, cultivar Guaçu, aos 56,70 e 84 dias de desenvolvimento.

6 Porcentagem de fibra em detergente neutro das forragens fresca e emurchecidas (inteira e triturada) do capim-elefante, cultivar Guaçu, aos 56,70 e 84 dias de desenvolvimento

7 Porcentagem de carboidratos solúveis das forragens fresca e emurchecidas (inteira e triturada) do capim-elefante, cultivar Guaçu, aos 56,70 e 84 dias de desenvolvimento.

8 Valores de poder tampão (em e.mg de $\mathrm{HCl} / 100 \mathrm{~g}$ de $\mathrm{MS}$ ) das forragens fresca e emurchecidas (inteira e triturada) do capim-elefante, cultivar Guaçu, aos 56, 70 e 84 dias de desenvolvimento

9 Densidade das silagens do capim-elefante $\left(\mathrm{em} \mathrm{kg} / \mathrm{m}^{3}\right)$, cultivar Guaçu, confeccionadas com as forragens fresca e emurchecidas (inteira e triturada), aos 56,70 e 84 dias de desenvolvimento 
10 Porcentagem de matéria seca das silagens do capim-elefante, cultivar Guaçu, confeccionadas com as forragens fresca e emurchecidas (inteira e triturada), aos 56,70 e 84 dias de desenvolvimento.

11 Valores de $\mathrm{pH}$ das silagens do capim-elefante, cultivar Guaçu, confeccionadas com as forragens fresca $e$ emurchecidas (inteira e triturada), aos 56,70 e 84 dias de desenvolvimento

12 Porcentagem de ácido láctico das silagens do capim-elefante, cultivar Guaçu, confeccionadas com as forragens fresca e emurchecidas (inteira e triturada), aos 56,70 e 84 dias de desenvolvimento

13 Porcentagem de ácido acético das silagens do capim-elefante, cultivar Guaçu, confeccionadas com as forragens fresca e emurchecidas (inteira e triturada), aos 56, 70 e 84 dias de desenvolvimento

14 Porcentagem de ácido propiônico das silagens do capim-elefante, cultivar Guaçu, confeccionadas com as forragens fresca e emurchecidas (inteira e triturada), aos 56,70 e 84 dias de desenvolvimento.

15 Porcentagem de ácido butírico das silagens do capim-elefante, cultivar Guaçu, confeccionadas com as forragens fresca e emurchecidas (inteira e triturada), aos 56,70 e 84 dias de desenvolvimento.

16 Porcentagem de nitrogênio amoniacal, em relação ao nitrogênio total, das silagens do capim-elefante, cultivar Guaçu, confeccionadas com as forragens fresca e emurchecidas (inteira e triturada), aos 56,70 e 84 dias desenvolvimento 
17 Valores de ingestão de matéria seca $\left(\mathrm{em} \mathrm{g} / \mathrm{kg}^{0,75} \mathrm{e}\right.$ em porcentagem do peso vivo) das silagens do capim-elefante, cultivar Guaçu, confeccionadas com as forragens fresca $e$ emurchecidas (inteira e triturada), aos 56, 70 e 84 dias de desenvolvimento.

18 Coeficientes de digestibilidade aparente (em \%) da matéria seca das silagens do capim-elefante, cultivar Guaçu, confeccionadas com as forragens fresca e emurchecidas (inteira e triturada), aos 56,70 e 84 dias de desenvolvimento.

19 Coeficientes de digestibilidade aparente da proteína bruta (em \%) das silagens do capim-elefante, cultivar Guaçu, confeccionadas com as forragens fresca e emurchecidas (inteira e triturada), aos 56,70 e 84 dias de desenvolvimento.

20 Coeficientes de digestibilidade da fibra bruta (em \%) das silagens do capim-elefante, cultivar Guaçu, confeccionadas com as forragens fresca e emurchecidas (inteira e triturada), aos 56, 70 e 84 dias de desenvolvimento.

21 Coeficientes de digestibilidade do extrato etéreo (em \%) das silagens do capim-elefante, cultivar Guaçu, confeccionadas com as forragens fresca e emurchecidas (inteira e triturada), aos 56, 70 e 84 dias de desenvolvimento.

22 Coeficientes de digestibilidade dos extrativos não nitrogenados (em \%) das silagens do capim-elefante, cultivar Guaçu, confeccionadas com as forragens fresca e emurchecidas (inteira e triturada), aos 56, 70 e 84 dias de desenvolvimento

23 Coeficientes de digestibilidade da fibra em detergente neutro (em \%) das silagens do capim-elefante, cultivar Guaçu, confeccionadas com as forragens fresca e emurchecidas (inteira e triturada), aos 56,70 e 84 dias de desenvolvimento 
24 Porcentagens de nutrientes digestiveis totais na matéria seca das silagens do capim-elefante, cultivar Guaçu, confeccionadas com as forragens fresca e emurchecidas (inteira e triturada), aos 56,70 e 84 dias de desenvolvimento.

25 Valores de ingestão de nutrientes digestiveis totais $\left(\mathrm{em} \mathrm{g} / \mathrm{kg}^{0,75}\right.$ ) das silagens do capim-elefante, cultivar Guaçu, confeccionadas com as forragens fresca e emurchecidas (inteira e triturada), aos 56,70 e 84

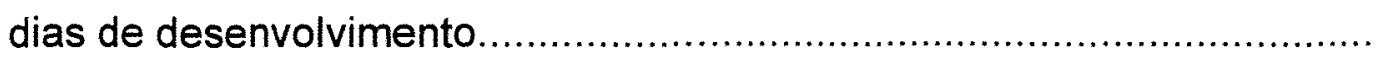




\section{LISTA DE FIGURAS}

Página

1 Variação da produção de matéria seca, em $\mathrm{kgMS} / \mathrm{ha}$, do capim-elefante, cultivar Guaçu, aos 56, 70 e 84 dias de desenvolvimento.

2 Variações das porcentagens de matéria seca de haste, lâmina e material morto na forragem do capim-elefante, cultivar Guaçu, aos 56, 70 e 84 dias de desenvolvimento.

3 Variações das porcentagens de matéria seca das forragens fresca e emurchecidas (inteira e triturada) do capim-elefante, cultivar Guaçu, aos 56,70 e 84 dias de desenvolvimento

4 Variaçōes das porcentagens de proteina bruta das forragens fresca e emurchecidas (inteira e triturada) do capim-elefante, cultivar Guaçu, aos 56,70 e 84 dias de desenvolvimento

5 Variações das porcentagens de fibra em detergente neutro das forragens fresca e emurchecidas (inteira e triturada) do capimelefante, cultivar Guaçu, aos 56, 70 e 84 dias de desenvolvimento........

6 Variações das porcentagens de carboidratos solúveis das forragens fresca e emurchecidas (inteira e triturada) do capim-elefante, cultivar Guaçu, aos 56, 70 e 84 dias de desenvolvimento

7 Variações dos valores de poder tampão das forragens fresca e emurchecidas (inteira e triturada) do capim-elefante, cultivar Guaçu, aos 56,70 e 84 dias de desenvolvimento.

8 Variações das porcentagens de matéria seca das silagens do capim-elefante, cultivar Guaçu, confeccionadas com as forragens fresca e emurchecidas (inteira e triturada), aos 56,70 e 84 dias de desenvolvimento 


\title{
SILAGEM DE CAPIM-ELEFANTE (Pennisetum purpureum Schum.), EM TRÊS ESTÁDIOS DE MATURIDADE, SUBMETIDO AO EMURCHECIMENTO
}

\author{
Autor: JOSE NARCISO SOBRINHO \\ Orientador: Prof. Dr. HERBERT BARBOSA DE MATTOS
}

\section{RESUMO}

Foram avaliados a produção de matéria seca do capim-elefante (Pennisetum purpureum Schum.), cultivar Guaçu, em três estádios de maturidade, a composição química de sua forragem fresca e emurchecida, bem como a qualidade e o valor nutritivo de suas silagens. Na determinação da produção de matéria seca, foram utilizadas 15 parcelas de $27,95 \mathrm{~m}^{2}$, sendo o capim rebaixado nas datas de 16/01/97, 30/01/97 e 13/02/97, para obtenção de forragens com 56, 70 e 84 dias de desenvolvimento, em 10/04/97. Cada parcela recebeu $100 \mathrm{~kg}$ de $\mathrm{N}, 80 \mathrm{~kg}$ de $\mathrm{P}_{2} \mathrm{O}_{5}$ e $100 \mathrm{~kg}$ de $\mathrm{K}_{2} \mathrm{O} / \mathrm{ha}$, utilizando-se sulfato de amônio, superfosfato simples e cloreto de potássio, respectivamente. As dosagens de nitrogênio e potássio foram divididas em duas aplicações, metade no corte de rebaixamento e o restante 28 dias após a primeira. $O$ experimento foi instalado obedecendo um delineamento inteiramente casualizado com 5 repetições por tratamento. A amostragem do experimento foi efetuada cortando-se, em cada parcela, toda a forragem existente, tendo em vista que as parcelas foram situadas no meio da cultura, não apresentando efeito de bordadura. Após pesagem da forragem, foram retiradas amostras para determinação do teor e produção de matéria seca, inclusive as porcentagens de haste, lâmina e material morto. O capim utilizado para a ensilagem foi rebaixado nas mesmas datas das parcelas referidas anteriormente, recebendo 
- mesmo tipo de adubação. As silagens foram confeccionadas com as forragens fresca e emurchecidas (inteira e triturada), sendo a desidratação da forragem inteira realizada no campo durante 24 horas ininterruptas. 0 emurchecimento da forragem triturada foi realizado em terreiro revestido de tijolos, sendo o material exposto ao sol durante 4 horas. Como silos experimentais, foram utilizados tambores plásticos de 150 litros de capacidade. Antes da ensilagem, foram retiradas amostras das forragens para determinação da composição bromatológica, teor de carboidratos solúveis e poder tampão. Nas silagens, foram determinados a densidade, $\mathrm{o} \mathrm{pH}$, a porcentagem de nitrogênio amoniacal, de ácidos orgânicos, a composição bromatológica e o valor nutritivo. $O$ experimento foi desenvolvido obedecendo um delineamento de blocos ao acaso com 3 repetições por tratamento. Os tratamentos foram arranjados num esquema fatorial $3 \times 3$ ( 3 idades de desenvolvimento do capim e 3 tipos de forragem). $O$ teste de consumo e digestibilidade aparente foi realizado com ovinos alojados em gaiolas individuais, dispondo de água e sal mineral à vontade. O período de adaptação foi de 10 dias, seguido do período de determinação do consumo voluntário e de coleta, com 10 e 7 dias de duração, respectivamente. Durante o periodo de coleta, os animais receberam $100 \%$ do consumo determinado. A produção de matéria seca cresceu com o aumento do intervalo de corte do capim, sendo a idade de 70 dias a que apresentou melhor equilibrio entre lâmina $e$ haste. As formas de emurchecimento utilizadas foram eficientes na elevação do teor de matéria seca da forragem, não reduzindo a porcentagem de carboidratos solúveis a ponto de comprometer a fermentação láctica. Por outro lado, esta técnica não apresentou vantagem qualitativa na ensilagem do capim-elefante, cultivar Guaçu, com teor de matéria seca igual ou superior a $21,20 \%$. O consumo voluntário aumentou com o emurchecimento da forragem inteira, porém os coeficientes de digestibilidade, a porcentagem de NDT e a ingestão de NDT não foram afetados com o emurchecimento. 


\title{
WILTED ELEPHANTGRASS (Pennisetum purpureum Schum.) SILAGE MADE FROM PLANTS CUT AT THREE MATURITY STAGES
}

\author{
Author: JOSÉ NARCISO SOBRINHO \\ Adviser: Prof. Dr. HERBERT BARBOSA DE MATTOS
}

\section{SUMMARY}

The present study was carried in order to evaluate the dry matter (DM) yield, DM chemical composition of green and wilted herbage, as well as the chemical composition of silages made from green and wilted herbage of elephantgrass (Pennisetum purpureum Schum.) cv. 'Guaçu'. To determine DM yield, fifteen $27.95-\mathrm{m}^{2}$ plots were harvested on 10 April at 56,70 , and 84 days of regrowth after staging on 16 Jan, 30 Jan, and 13 Feb 1997, respectively. Each plot received $100 \mathrm{~kg} \mathrm{~N}, 80 \mathrm{~kg} \mathrm{P} \mathrm{P}_{2} \mathrm{O}_{5}$, and $100 \mathrm{~kg} \mathrm{k}_{2} \mathrm{O}$ as $\left(\mathrm{NH}_{4}\right)_{2} \mathrm{SO}_{4}$, simple superphosphate, and $\mathrm{KCl}$, respectively. Nitrogen and potassium were split-applied, one half at staging and the other half 28 days later. The trial was set up in a completely randomized design with five replications per treatment. Sampling was done by clipping each plot entirely, as the plots were set in the middle of the pasture and thus there were no border effects. After weighing, the green herbage was subsampled for determination of DM concentration and yield, weights of leaf and stem fractions plus dead material. The plots used for making silage were staged on the same dates and received the same fertilization. Silages were made from both fresh and wilted herbage, whole and chopped plants, with whole plants being dehydrated for 24 $h$ under field conditions. Chopped herbage was wilted in the sun for $4 \mathrm{~h}$ on a brick-floored area. Experimental silos were 150-L plastic drums. Before ensiling 
the material was sampled and sent to the laboratory for determination of chemical composition, soluble carbohydrate concentration, and buffering capacity. The ensiled material was analyzed for density, $\mathrm{pH}$, concentrations of ammonia- $\mathrm{N}$ and organic acids, chemical composition and quality. The feeding trial was set up in a randomized complete block design with three replications. Treatments consisted of all possible combinations of three forage ages (maturities) and three types of forage (thus a $3 \times 3$ factorial). Evaluation of intake and in vivo digestibility was done using sheep in crates with water and mineral supplement supplied ad libitum. A 10-day adaptation period was followed by 10 days for detemining intake and 7 days of collection. During the collection period $100 \%$ of the intake was offered. Dry matter yield increased with regrowth interval, with the best leaf:stem ratio observed at 70 days. The wilting methods raised DM concentration satisfactorily and did not reduce soluble carbohydrate concentrations to the point where lactic fermentation was compromised. Conversely, this technique did not improve quality of Guaçu elephantgrass silage when forage DM concentration was higher than $21.2 \%$. Voluntary intake increased with wilting of whole plants before ensiling although digestibility, TDN concentration, and TDN intake were not affected by wilting. 


\section{INTRODUÇÃO}

Devido à estacionalidade de produção das plantas forrageiras tropicais, há excesso de forragem no período chuvoso e escassez na época seca, comprometendo seriamente a produção dos ruminantes. Assim sendo, a técnica de conservação se constitui numa alternativa viável para corrigir os efeitos da irregularidade de produção de forragem ao longo do ano.

O processo de conservação, através da ensilagem, tem sido utilizado não apenas nos países tropicais mas em outras partes do mundo. No Brasil, a conservação de forragem é necessária em razão dos aspectos levantados.

Das forrageiras tropicais, o capim-elefante vem sendo utilizado com grande frequência para produção de silagem, devido à grande quantidade de biomassa produzida por área, quando comparado com as demais espécies. Além disso, trata-se de uma planta perene evitando-se gastos anuais de implantação da cultura.

Embora o capim-elefante apresente um grande rendimento por área, seu elevado teor de umidade compromete a qualidade da silagem. Com isso, torna-se necessária a utilização de técnicas que possam elevar o teor de matéria seca da forragem, para níveis satisfatórios do ponto de vista da fermentação, no interior do silo. Dessa forma, o emurchecimento pode ser usado para proporcionar um teor de matéria seca na forragem adequado à ensilagem, principalmente, para a planta jovem, a qual apresenta valor nutritivo mais elevado. 
Mesmo reconhecendo que a desidratação do capim-elefante seja difícil, em conseqüência da resistência física que a parede celular apresenta, notadamente no caule, a técnica do emurchecimento é um dos métodos mais eficientes para se reduzir perdas por drenagem e fermentações secundárias na ensilagem de forragens imaturas. É uma das técnicas recomendáveis quando a forragem apresenta teor de matéria seca abaixo de $20 \%$. Acredita-se que a baixa perda de umidade encontrada por vários trabalhos que realizaram o emurchecimento do capim-elefante deve estar associada ao pequeno período de exposição da forragem ao sol.

Em face do exposto, o presente trabalho teve como objetivos determinar a produção e a composição química da matéria seca do capimelefante, cultivar Guaçu, em três estádios de maturidade, e estudar a qualidade e o valor nutritivo das silagens produzidas com a forragem fresca e emurchecida. 


\section{REVISÃO DE LITERATURA}

\subsection{O capim-elefante e seu potencial forrageiro para ensilagem}

O capim-elefante (Pennisetum purpureum Schum.), originário da África, foi introduzido no Brasil em 1920 (Carvalho et al., 1982). Segundo Rodrigues et al. (1975), seu habitat situa-se entre $10^{\circ}$ de latitude $\mathrm{N}$ e $20^{\circ}$ de latitude S. Sua principal característica é a grande produção por área, o que diferencia de outras espécies de capins tropicais (Zuñiga et al., 1967; Gomide et al., 1974 e Alvim et al., 1986). Encontra-se disseminado, praticamente, em todo território brasileiro, ligado, principalmente, à produção de leite, predominando sua utilização na forma de capineira (Hillesheim, 1993).

Embora tenham sido divulgadas inúmeras vantagens para as capineiras, sua utilização não é fácil, devido à dificuldade de ajustar o corte ao estádio de maturidade da planta, levando ao uso de forragem passada (Faria, 1993). Ghielfi (1972) e Rolin (1986) revelaram também que o aproveitamento das capineiras para suplementação de forragem de boa qualidade na época seca é difícil em conseqüência da acentuada estacionalidade de produção de matéria seca. Faria (1994) ressaltou que a difusão da técnica de corte e distribuição de alimento no cocho tenha sido um dos fatores responsáveis pela perpetuação da subnutrição nos rebanhos brasileiros e que a utilização do capim-elefante possa ter contribuído decisivamente para o atraso tecnológico em nosso meio. 
Apesar das restrições atribuídas à ensilagem do capimelefante, a técnica tem sido incrementada no país, obtendo-se bons resultados (Faria, 1994). Trabalhos de pesquisa junto à Universidade da Flórida, nos Estados Unidos (Ruiz et al., 1992), mostraram que silagens de capim-elefante anão, confeccionadas sem aditivos ou preservativos, foram consideradas como de boa qualidade para vacas leiteiras, quando substituíram parcialmente a silagem de milho na dieta.

Uma grande parte das informações sobre a produção forrageira do capim-elefante está relacionada aos cultivares Napier, Mineiro, Cameron, Taiwan, Porto Rico, Vruckwona, Mercker, Merckeron e Turrialba (Tcacenco \& Botrel, 1994). Segundo Andrade \& Nucci (1982), os cultivares mais estudados para silagem em São Paulo são Napier, Taiwan A-144 e A148, Vruckwona, Cameron e Mineiro. Canto et al. (1974) encontraram, independentemente da altura de corte, produção anual de 162,5 toneladas de matéria verde/hectare para o cultivar Porto Rico, eqüivalendo a 29,7 toneladas de matéria seca.

Pedreira \& Boin (1969) estudaram o crescimento do capimelefante, cultivar Napier, e observaram que, dos 21 aos 210 dias de desenvolvimento, a produção de matéria seca subiu de 2,7 a 27,1 toneladas/ha/ano, ocorrendo, no entanto, decréscimo de proteína bruta de 17,3 a $2,9 \%$ e aumento de fibra bruta de $26,2 \%$ para $43,9 \%$. Yeo (1977), ao avaliar o efeito da maturidade do capim-elefante cortado entre 40 e 160 dias de crescimento, constatou aumento significativo na produção de matéria seca (de 5,75 a 34,43 toneladas/ha), porém os teores de proteina bruta, extrato etéreo, cinzas e conteúdo celular decresceram significativamente, passando, respectivamente, de 8,$12 ; 3,08 ; 16,09$ e $36,87 \%$, no primeiro corte, para 3,56 ; 1,$84 ; 10,32$ e $27,97 \%$, no último corte. Além disso, as frações fibrosas aumentaram com a maturidade, resultando em queda do valor nutritivo do capim, em face da redução da digestibilidade. 
Andrade \& Gomide (1971) aconselharam o uso de capimelefante para ensilagem entre 56 e 140 dias de desenvolvimento a uma altura da planta de 170 a $280 \mathrm{~cm}$, baseando-se no teor de carboidratos solúveis da planta, o qual variou de 14,8 a $14,3 \%$ na matéria seca. Vilela et al. (1981) estudaram três alturas da planta do capim-elefante para ensilagem e estabeleceram que a melhor época para o corte, baseando-se no seu rendimento por unidade de área e no valor nutritivo das silagens correspondentes, foi quando este apresentava, aproximadamente, $183 \mathrm{~cm}$ de altura, o que correspondeu a 77 dias de idade.

As forragens de baixa qualidade, invariavelmente, originarão silagens nutricionalmente inadequadas e o momento de corte do capimelefante para ensilagem passa a ser de alta relevância, não só pelo fato de que se deva aliar produtividade e bom valor nutritivo, mas também porque a composição desta forrageira, em termos de matéria seca, carboidratos solúveis e poder tampão, interferirá, grandemente, na fermentação e, conseqüentemente, sobre a qualidade da silagem (Lavezzo, 1993).

Pedreira \& Boin (1969) estabeleceram, para o cultivar Napier, que a altura da planta adequada para ensilagem estaria ao redor de 2,40 metros, ou seja, dos 84 aos 105 dias de desenvolvimento, pois, nestas condições, o baixo valor nutritivo do material seria compensado pelo rendimento mais elevado de matéria seca. Concordando em parte com esses dois autores, Johnson et al. (1973) estabeleceram a conveniência da utilização mais precoce do capim-elefante, ou seja, com desenvolvimento vegetativo não ultrapassando 84 dias.

Andrade (1995), trabalhando com o capim-elefante, cultivar Guaçu, cortado aos 62 dias de desenvolvimento, encontrou elevado teor de proteina, porém baixo teor de matéria seca, $10,46 \%$ e $12,40 \%$, respectivamente. Gennari \& Mattos (1977) verificaram para três cultivares de capim-elefante, cortados aos 42,63 e 84 dias de crescimento, que aos 63 dias 
as forrageiras mostravam melhores correlações entre digestibilidade, produção de matéria seca, proteína bruta e lignina.

Segundo Spain \& Santiago (1973), o ponto de equilibrio entre valor nutritivo e produção de matéria seca para o capim-elefante é alcançado quando este contiver 8 a 10 entrenós em início de expansão. Neste estádio, o capim deve proporcionar boa quantidade de folhas, pois estas são nutricionalmente mais ricas e mais digestiveis (Arias \& Butterworth, 1966; Britto et al., 1966; Rodriguez \& Blanco, 1970 e Santana et al., 1989), e razoável proporção de caules, pois estes são mais ricos que as folhas em carboidratos solúveis (Gutierrez et al., 1976).

Devido ao elevado número de cultivares da espécie, torna-se difícil generalizar seu corte para ensilagem, numa mesma idade, quando a relação haste/folha for igual a um, porém esta passa a ser um parâmetro balizador, a qual será obtida com a gramínea na faixa dos 70 aos 90 dias (Lavezzo, 1993). Vilela (1994), de forma abrangente, também concluiu que, das informações levantadas, o momento de corte adequado seria quando o capimelefante estivesse com 70 dias de crescimento, o que eqüivaleria à altura de $1,90 \mathrm{~m}$, tendo a forragem, nesta oportunidade, cerca de $18,6 \%$ de matéria seca.

Desde que exista entre os pesquisadores e técnicos a concordância de que o capim-elefante deve ser ensilado ainda novo, pode-se imaginar que, simultaneamente ao ocorrido com a grande maioria das forrageiras tropicais, este capim apresente poder tampão mais elevado e baixos teores de carboidratos solúveis, quando comparado com o estádio mais avançado, o que impediria a confecção de silagens de boa qualidade (Lavezzo, 1993). Quanto ao poder tampão, Faria (1971), trabalhando com o capimelefante, cultivar Napier, verificou redução acentuada na capacidade tampão ao ácido láctico com a maturidade da planta, tendo determinado aos 51,86 e 121 dias de desenvolvimento valores de 55,26; 44,97 e 36,81 mg de ácido 
láctico por g de matéria seca, respectivamente. De maneira semelhante, Gutierrez (1975) observou que a maturidade foi responsável pelo decréscimo nos ácidos orgânicos do capim-elefante, como conseqüência, o seu poder tampão, que estava ao redor de 38 a 48 e.mg de $\mathrm{HCl} / 100 \mathrm{~g}$ de matéria seca aos 37 dias, caiu para 14 a 16 e.mg de $\mathrm{HCl} / 100 \mathrm{~g}$ de matéria seca aos 67 dias e 13 a 15 e.mg de $\mathrm{HCl} / 100 \mathrm{~g}$ de matéria seca aos 97 dias de desenvolvimento.

Knabe \& Weise (1974) mostraram que, quando a relação entre carboidratos solúveis e poder tampão diminui, um teor mínimo de matéria seca é requerido para evitar fermentações indesejáveis no silo. $\mathrm{Na}$ ensilagem de plantas que apresentam teor de matéria seca inferior a $21 \%$, carboidratos solúveis inferior a $2,2 \%$ na matéria verde e baixa relação entre carboidratos solúveis e poder tampão, os riscos de fermentações secundárias são maiores, tornando-se imprescindíveis o uso de recursos que, de alguma forma, modifiquem este quadro (Weibbach et al., 1974 e Wilkinson et al., 1982). Segundo Knabe \& Weise (1974), os fatores que controlam as fermentações secundárias são a atividade da água, proveniente da própria umidade da planta, e a acidez, sendo que o teor de matéria seca original da planta pode ser tomado como medida dessa atividade e o quociente açúcar original/poder tampão pode servir como indicador da acidez.

Wilkinson et al. (1982) concluíram, a partir do estudo de 231 silagens preparadas com plantas de clima temperado, que o nível adequado de carboidratos solúveis, para que a fermentação seja julgada estável, baixo $\mathrm{pH}$ e ácido láctico dominante, deve ser de $3 \%$ do peso verde da planta. Se o nível de carboidratos estiver abaixo de $2 \%$, existirá a probabilidade de ocorrer fermentaçōes secundárias.

Uma análise da relação entre a proporção de nitrogênio presente como nitrogênio amoniacal, um dos indicadores da extensão das fermentações secundárias, e o teor de carboidratos solúveis, em 31 gramíneas de origem tropical, revelou uma faixa crítica entre 2,5 a $3,0 \%$ na base da 
matéria verde (Wilkinson, 1983). Para se ter uma boa preservação da forrageira ensilada, é necessário que o teor de carboidratos esteja acima deste nivel.

As forragens que apresentam baixo teor de carboidratos solúveis e elevado poder tampão podem ser ensiladas satisfatoriamente, desde que apresentem teor de matéria seca superior a 30\% (Gordon, 1967; Gordon et al., 1967 e Whittenbury et al., 1967). Segundo McDonald (1981), silagens efetuadas com forragens contendo baixo teor de matéria seca desencadeiam perdas por drenagem e propiciam o desenvolvimento de bactérias do gênero Clostridium devido ao excesso de umidade da forragem. $O$ desenvolvimento de tais bactérias produz fermentações secundárias indesejáveis, havendo a formação de ácido butírico o qual caracteriza silagens de baixa qualidade. Quando há formação de ácido butírico, ocorre, concomitantemente, degradação de proteína e ácido láctico. Wieringa (1960) afirmou que os microorganismos do gênero Clostridium são mais inibidos pela carência de umidade do que a acidez do meio. Estes microorganismos toleram altas concentrações de ácidos e íons de hidrogênio no material úmido e quanto mais úmido o material, mais baixo será $\circ \mathrm{pH}$ necessário para a conservação da forragem (Wieringa, 1958).

O teor de carboidratos de $10 \%$, na matéria seca, foi considerado suficiente para obtenção de uma boa silagem por Lanigan \& Catchpoole (1962). Catchpoole \& Henzel (1971) concluiram que as forragens tropicais a serem ensiladas deveriam apresentar teor de carboidratos solúveis de 13 a 16\%. Segundo McCulloug (1977), a fermentação ideal no silo é esperada quando a forragem a ser ensilada possua de 28 a $34 \%$ de matéria seca. Para este autor, nestas condições, mesmo teores de carboidratos solúveis de 6 a $8 \%$, na matéria seca, seriam suficientes para desencadear fermentações lácticas, desde que o poder tampão não seja elevado. 
Os teores de matéria seca de 28 a $34 \%$ somente são alcançados quando 0 capim-elefante se encontra num estádio de desenvolvimento avançado (Pedreira \& Boin, 1969; Andrade \& Gomide, $1971 \mathrm{e}$ Azevedo et al., 1986). Segundo Lavezzo (1993), este estádio é incompativel com uma silagem de valor nutritivo aceitável, sendo a melhor alternativa ensilálo quando novo, lançando mão de técnicas que reduzam a ação deletéria da umidade excessiva da planta, a exemplo do emurchecimento. 0 emurchecimento significa a redução parcial de água da planta, possibilitando a obtenção de silagens de melhores qualidades se comparadas àquelas feitas com a forragem fresca (Tosi, 1973). A desidratação da forragem proporciona melhoria na fermentação, diminuição na perda de nutrientes por drenagem e principalmente aumento no consumo animal, devido à sua relação positiva com o teor de matéria seca da silagem.

O emurchecimento de forrageiras temperadas, visando um conteúdo de matéria seca igual ou superior a $30 \%$, é preconizado por muitos autores. Catchpoole (1972) constatou que tal medida reduziu o fluxo de efluentes e o crescimento de clostrídeos. Por outro lado, a diminuição da umidade parece não afetar a atividade das bactérias lácticas, uma vez que, segundo De Vuyst \& Vanbelle (1969), elas são mais resistentes à pressão osmótica. Além disso, a redução da umidade das forragens a serem ensiladas diminui a capacidade tamponante do material (McDonald et al., 1965 e Playne \& McDonald, 1966), bem como diminui, na ensilagem, a disponibilidade de íons inorgânicos para a formação de novos sistemas tampões com os ácidos orgânicos produzidos durante o processo de fermentação (Smith, 1962).

Em forragens com menos de $20 \%$ de matéria seca no momento da ensilagem, a umidade excessiva, invariavelmente, reduzirá os efeitos preservativos das fermentações ácidas primárias e o crescimento das bactérias do gênero clostridium poderá não estar restringido em $\mathrm{pH}$ tão baixo quanto 3,8 a 4,0 (Lavezzo, 1993). Weringa (1958) revelou que a atividade dos clostrídeos 
é controlada pelo $\mathrm{pH}$ e a pressão osmótica. Como a pressão osmótica do interior das células vegetais aumenta com o decréscimo do conteúdo de umidade da planta, entende-se o benefício de seu murchamento, antes de ensilá-la. Por outro lado, Gordon et al. (1965) admitiram que, quando a massa ensilada possui teor de matéria seca superior a $50 \%$, dificulta a compactação no interior do silo, não havendo eliminação total do ar, o que acarreta, conseqüentemente, aquecimento da massa e cria condições favoráveis ao desenvolvimento de mofos.

Os resultados experimentais decorrentes da prática de emurchecimento, após o corte manual do capim-elefante, têm sido contraditórios. Em alguns trabalhos não se verificou vantagem na utilização dessa prática (Faria, 1971 e Tosi, 1973). Em outros, verificou-se melhoria nos aspectos qualitativos e nutricionais das silagens (Ferreira et al., 1974 e Vilela \& Wilkinson, 1987). Na maioria dos trabalhos, o emurchecimento da planta inteira, durante quatro a seis horas ao sol, tem feito com que o teor de matéria seca não se eleve além de três a oito unidades percentuais (Faria, 1971; Tosi, 1973; Tosi et al., 1983b e Lavezzo et al., 1983).

Vilela \& Wilkinson (1987), após triturarem o capim-elefante Mineiro, submeteram-no, antes da ensilagem, ao emurchecimento por $0,6,30$ e 54 horas ao sol e verificaram aumento no teor de matéria seca e no pH das silagens. Por outro lado, foram observadas reduções nos teores de ácido acético e nitrogênio amoniacal. Observaram, ainda, aumento no teor de carboidratos solúveis quando a forragem ficou exposta ao sol durante 6 horas, registrando-se redução à medida que se aumentou o tempo de exposição do material ao sol. Para o ácido butírico, houve aumento nos tratamentos com $6 \mathrm{e}$ 30 horas, não verificando sua presença no último tratamento.

Tosi et al. (1995), trabalhando com capim-elefante, cultivar Mott, conseguiram elevar o teor de matéria seca de 14,1 para $41,3 \%$ quando a planta inteira foi submetida ao emurchecimento à sombra, durante 30 horas. 
Quando utilizaram a forragem triturada e submetida ao mesmo tipo de emurchecimento, o aumento no teor de matéria seca foi baixo passando de 14,1 para $18,3 \%$, devido ao adensamento da massa durante a desidratação.

Faria (1971) encontrou decréscimo no poder tampão ao ácido láctico, de 44,97 a $35,73 \mathrm{mg} / \mathrm{g}$ de MS, quando o capim-elefante, cultivar Napier, colhido aos 86 dias de desenvolvimento, foi submetido ao emurchecimento durante 6 horas. Gutierrez \& Faria (1978) concluíram que o capim-elefante, cultivar Taiwan A-148, cortado aos 62 dias de desenvolvimento e submetido ao emurchecimento por $0,2,4$ e 6 horas não reduziu o poder tampão ao ácido clorídrico, haja vista que os resultados encontrados foram de 21,$05 ; 21,82$; 21,64 e 20,92 e.mg de $\mathrm{HCl} / 100 \mathrm{~g}$ de $\mathrm{MS}$, respectivamente. Constataram, ainda, redução não significativa dos ácidos orgânicos totais $(92,81 ; 74,53 ; 74,06 \mathrm{e}$ 75,99 e.mg de $\mathrm{HCl} / 100 \mathrm{~g}$ de MS, respectivamente). Por outro lado, Tosi (1973) não observou diferenças significativas no poder tampão do capim-elefante Taiwan A-148, quando submetido ao emurchecimento por 6 horas de exposição ao sol.

Lopes \& Monks (1983) verificaram que a elevação do teor de matéria seca do capim-elefante para niveis acima de $30 \%$, antes da ensilagem, não garante, necessariamente, fermentação mais restrita na silagem, haja vista a elevação da amônia, do ácido láctico e do $\mathrm{pH}$, os quais passaram de 9,23 para $9,33 \%, 5,36$ para $5,50 \%$ e 3,8 para 4,0 , respectivamente, para silagens de capins verdes $(29,60 \%$ de MS) e emurchecidos (36,90\% de MS).

Como regra geral, tem-se que a redução da umidade da forragem, por meio do emurchecimento, aumenta a eficiência de preservação da silagem (Roffler et al., 1967; Wilkins et al., 1971 e Morgan et al., 1980), o consumo voluntário e a digestibilidade (Grant et al., 1974; Ferreira et al., 1974 e Vilela \& Wilkinson, 1987). 


\subsection{Qualidade e valor nutritivo da silagem}

O processo de ensilagem não melhora a composição química das forragens, mas visa mantê-la estável por mais tempo, por isso torna-se importante que o material ensilado seja de boa qualidade (McDonald, 1981).

O valor nutritivo de uma silagem pode ser considerade função do consumo voluntário, digestibilidade e eficiência pelo qual os nutrientes são utilizados (Lavezzo, 1993). Porém, o principal fator que limita a produção dos animais ingerindo silagens é o nível de consumo voluntário. Segundo Wilkins \& Wilson (1970), o consumo de matéria seca da silagem pode corresponder a $70 \%$ do consumo do mesmo alimento desidratado. Lancaster \& Rattray (1977) afirmaram que tal consumo corresponde à metade do que seria com a forragem original da qual a silagem foi confeccionada.

A redução no consumo de silagem é causada pelas mudanças químicas que ocorrem durante a fermentação no silo (Wilkins et al., 1971). Por outro lado, muitos estudos mostraram correlação positiva entre o consumo de matéria seca e o seu respectivo teor na silagem (Gordon et al., 1961; Moore et al., 1960 e Thomas et al., 1961). Jackson \& Forbes (1970) relataram uma relação curvilínea entre o nível de matéria seca da silagem e seu consumo, estabelecendo que o teor de $35,5 \%$ de matéria seca propiciaria a máxima ingestão. Verificaram, ainda, que existe uma correlação linear e significativa $(r=-0,56)$ entre o conteúdo de ácido acético das silagens e o seu consumo voluntário.

Ferreira et al. (1974) cortaram o capim-elefante em três estádios de desenvolvimento e o submeteram ao emurchecimento, tendo observado consumo médio diário, por unidade de peso metabólico, de $42,6 \mathrm{~g}$ para a matéria seca e de $20,4 \mathrm{~g}$ para a matéria seca digestível da silagem, sendo que, nas testemunhas, os valores foram de 38,8 e 16,6, respectivamente. Tosi (1978), trabalhando com o capim-elefante Taiwan A-148, 
colhido com 50-55 dias de idade, submeteu-o ao emurchecimento, à adição ou não de $4 \%$ de melaço e verificou uma elevação no consumo de matéria seca por unidade de peso metabólico. A ingestão de matéria seca passou de $29,4 \mathrm{~g}$ da testemunha para 39,66 e $38,4 \mathrm{~g}$ para os tratamentos com emurchecimento acentuado ( 12 horas e 30 minutos) e moderado ( 8 horas), sem o melaço.

O aumento no consumo voluntário de silagens, confeccionadas com forragens que sofreram emurchecimento prévio, está associado com a menor concentração de ácidos graxos voláteis e teor de nitrogênio amoniacal (Jackson \& Forbes, 1970). Wilkins et al. (1971) observaram que apenas 15,8\% da variação no consumo podem ser atribuídos ao teor de matéria seca da forragem, ao mesmo tempo que estabeleceram ser mais decisiva ao consumo de silagens a intensidade da degradação dos nutrientes no interior do silo. Wilkins et al. (1971) e Demarquilly (1973) identificaram que as correlações entre consumo e o teor de matéria seca da forragem não foram tão altas quanto aquelas entre o consumo e o teor de ácidos voláteis (tais como o ácido acético) ou a proporção de nitrogênio presente como amônia.

Correlacionando a aceitação de 70 tipos diferentes de silagens com os vários parâmetros indicadores de suas qualidades, Wilkinson et al. (1976) destacaram o efeito depressivo do ácido acético, ácido butírico, nitrogênio amoniacal e aminas sobre o consumo voluntário de silagens. Gordon et al. (1965) encontraram correlação favorável entre consumo e teor de matéria seca da silagem, desde que esta apresente menos de $50 \%$ de matéria seca. Assim, a melhor utilização de forragem com emurchecimento é reflexo da melhor qualidade na sua preservação no silo, especialmente quando o teor de umidade e de ácido acético é reduzido (Forbes \& Jackson, 1971).

Silveira et al. (1980) trabalharam com quatro cultivares de capim-elefante, Napier, Taiwan A-144, Mineiro e Vrukwona, aos 60 dias de idade, ensilando-os sem emurchecimento ou após seis horas de exposição ao sol. Encontraram correlação altamente significativa entre o consumo de matéria 
seca e os constituintes das silagens, como: matéria seca, ácido acético, ácido butírico, nitrogênio amoniacal e $\mathrm{pH}$, cujos coeficientes foram $0,47,-0,86,-0,68$, $-0,78$ e $-0,71$, respectivamente. Os autores concluíram que, por apresentarem altas percentagens de umidade, as silagens de capim-elefante revelaram, em média, baixa aceitação pelos animais no teste de consumo, com $37,6 \mathrm{~g}$ MS/UPM, principalmente em conseqüência das elevadas taxas de ácido acético. Porém, o emurchecimento proporcionou consumo médio de $44,6 \mathrm{~g}$ de MS/UPM, com destaque para o cultivar Mineiro, com consumo médio de $49,3 \mathrm{~g}$ de MS/UPM. Chenost \& Demarquilly (1982) comentaram que o consumo de silagens feitas com a forragem desidratada pode aumentar, no caso em que as forrageiras que deram origem à silagem continham muita umidade, ou seja, inferior a $18 \%$ de matéria seca.

A restrição do consumo em silagens mal preservadas pode estar associada aos produtos da degradação protéica (Neumark et al., 1964 e Neumark \& Tadmor, 1968). Wilkins \& Wilson (1970) afirmaram que o conteúdo de ácidos livres contidos na silagem influenciam o consumo. Harris \& Raymond (1963) encontraram correlações negativas entre o consumo e os teores de amônia e ácido butírico quando mensuraram a digestibilidade de silagens de várias forragens.

Lavezzo et al. (1984), trabalhando com dois cultivares de capim-elefante colhidos aos 60 dias de desenvolvimento e submetidos ao emurchecimento, adição de formol, ácido fórmico e mistura "Viher", constaram consumo de matéria seca e matéria seca digestível das silagens com capim emurchecido de 42,44 e $27,15 \mathrm{~g} / \mathrm{UPM}$, respectivamente, tratadas com formol de $38,13 \mathrm{~g} / \mathrm{UPM}$ e $21,20 \mathrm{~g} / \mathrm{UPM}$, respectivamente, e com ácido fórmico de 35,84 e 21,61 g/UPM, respectivamente. Embora não tenha havido diferença significativa entre os tratamentos, a silagem de capim emurchecido apresentou, em valor absoluto, maior consumo. Por outro lado, os autores verificaram a existência de correlação significativa entre o consumo e o teor de matéria seca 
das silagens $(r=0,50)$, ácido acético $(r=-0,57)$, propiônico $(r=-0,34)$, butírico $(r=-0,59)$ e nitrogênio amoniacal $(r=-0,57)$.

Catchapoole \& Henzel (1971) afirmaram que forragens tropicais de difícil ensilagem apresentam baixo coeficiente de digestibilidade. Porém, 0 uso de aditivos ou técnicas visando melhorar a preservação da forragem antes da ensilagem podem diminuir a queda da digestibilidade, bem como melhorar a fermentação. Uma dessas técnicas é o emurchecimento, cujo efeito sobre a digestibilidade da matéria seca das silagens de capim-elefante tem ocasionado resultados variados. Ferreira et al. (1974) verificaram que houve aumento na digestibilidade da matéria seca e da proteína em relação à testemunha quando ensilaram o capim-elefante emurchecido, passando de 44 para $47,1 \%$ e de 23,8 para $29,0 \%$, respectivamente. Por outro lado, Jackson e Forbes (1970) constataram uma redução na digestibilidade da matéria seca e da energia em relação à testemunha quando ensilaram forragens emurchecidas.

Vilela \& Wilkinson (1987), ensilando o capim-elefante aos 60 dias de desenvolvimento, após trituração e emurchecimento da forragem ao sol por 0,630 e 54 horas, constataram diferenças significativas na digestibilidade "in vitro" da matéria seca $(41,2 ; 43,5 ; 50,2$ e $50,7 \%$, respectivamente) e da matéria orgânica $(39,7 ; 43,9 ; 49,0$ e $49,9 \%$, respectivamente).

Pelletier et al. (1976) não verificaram diferenças nas silagens de gramíneas emurchecidas até $30 \%$ de matéria seca com e sem ácido fórmico quanto às digestibilidades da matéria seca e parede celular. Silveira et al. (1973) não encontraram diferenças significativas entre o coeficiente de digestibilidade médio "in vitro" da matéria seca de silagens de forragens emurchecidas em relação à testemunha, $49,2 \%$ e $48,9 \%$, respectivamente. Tosi (1978) não constatou diferenças entre os coeficientes de digestibilidade de silagens de capim-elefante, cultivar Taiwan A-148, quando a forragem foi submetida ao emurchecimento por 8 horas e por 12 horas e 30 minutos. 
Lavezzo et al. (1989) não verificaram aumento nos coeficientes de digestibilidade aparente da matéria seca em relação à testemunha (51,2 e $51,9 \%$, respectivamente), quando ensilaram o capim-elefante, cultivar roxo, aos 60 dias de desenvolvimento, emurchecido por 8 horas ao sol. Por outro lado, constataram aumento significativo no coeficiente de digestibilidade da proteína bruta em relação à testemunha, passando de 54,4 para $62,5 \%$. 


\section{MATERIAL E MÉTODOS}

Como material de estudo foi utilizado o capim-elefante (Pennisetum purpureum Schum.), cultivar Guaçu. A capineira usada para fornecimento da forragem já se encontrava estabelecida, na Estação Experimental do Instituto de Zootecnia do Estado de São Paulo, Posto de Brotas-SP. O município de Brotas está localizado a uma altitude de 650 metros, latitude de $22^{\circ} 16^{\prime} \mathrm{S}$ e longitude de $48^{\circ} 07^{\prime} \mathrm{W}$. O solo do local do experimento é classificado como areia quartzosa.

\subsection{Avaliação da produção do capim-elefante}

Foram utilizadas 15 parcelas de $27,96 \mathrm{~m}^{2}$ para determinação da produção de matéria seca. O capim das parcelas foi rebaixado nas datas de 16/01/97, 30/01/97 e 13/02/97, para obtenção de forragens com 56, 70 e 84 dias de desenvolvimento, em 10/04/97.

Cada parcela foi adubada com $100 \mathrm{~kg}$ de $\mathrm{N}, 80 \mathrm{~kg}$ de $\mathrm{P}_{2} \mathrm{O}_{5}$ e 100 de $\mathrm{K}_{2} \mathrm{O} / \mathrm{ha}$, utilizando-se sulfato de amônio, superfosfato simples e cloreto de potássio, respectivamente. As dosagens de nitrogênio e potássio foram divididas em duas aplicações, metade no corte de rebaixamento e o restante 28 dias após a primeira. 
O experimento foi instalado obedecendo um delineamento inteiramente casualizado com 5 repetições por tratamento. As médias das características foram comparadas através do teste de Tukey a $5 \%$ de probabilidade. As análises de variância e de regressão foram realizadas pelo Sistema de Análise Estatística para Microcomputadores - SANEST.

A amostragem do experimento foi efetuada cortando-se, em cada parcela, toda a forragem existente, tendo em vista que as parcelas foram situadas no meio da cultura, não apresentando efeito de bordadura. Toda forragem colhida foi pesada, retirando-se uma amostra, de aproximadamente $1 \mathrm{~kg}$, e colocando-a em estufa regulada a $65^{\circ} \mathrm{C}$ para secagem até atingir peso constante. Após esfriamento e pesagem da amostra, foi determinado o teor de matéria seca a $65^{\circ} \mathrm{C}$. Em seguida, a amostra foi submetida à moagem com peneira de $1 \mathrm{~mm}$ e armazenada para determinação da porcentagem de matéria seca (MS) a $105^{\circ} \mathrm{C}$. Uma outra amostra de mesmo peso foi retirada para determinação das porcentagens de haste, lâmina e material morto, os quais foram separados manualmente, destacando-se a lâmina na lígula da folha. Cada uma destas partes foi amostrada, seguindo o mesmo procedimento para a amostra anterior.

\subsection{Determinação da composição química das forragens, da qualidade e} do valor nutritivo das silagens

Para confecção das silagens, foi utilizada uma área de 1.470 $\mathrm{m}^{2}$ subdividida em três parcelas iguais de $490 \mathrm{~m}^{2}$, sendo o capim das parcelas rebaixado nas mesmas datas utilizadas no item anterior referente à avaliação da produção do capim-elefante, para obtenção de forragens com 56, 70 e 84 dias de desenvolvimento no momento da ensilagem, 10/04/97.

As parcelas foram adubadas com as mesmas dosagens utilizadas no item anterior referente à produção do capim. 
O corte do capim foi feito manualmente e em seguida processado através de picadora de forragem, regulada para triturar a forragem em porções de $5 \mathrm{~mm}$. No tratamento em que a planta foi emurchecida inteira, a trituração da forragem somente foi realizada após a desidratação da planta.

As silagens, dentro de cada idade, foram confeccionadas com a forragem fresca e emurchecida ao sol. Foram efetuados dois tipos de emurchecimento, um com a planta inteira no campo durante 24 horas e o outro com a planta triturada (em porções de $5 \mathrm{~mm}$ ) e exposta ao sol durante um período de 4 horas.

Para o segundo emurchecimento, a forragem foi colocada em terreiro revestido de tijolos, em leiras de aproximadamente $10 \times 20 \mathrm{~cm}$ de altura e largura da base. Durante o periodo de 4 horas, a forragem foi revolvida ao menos duas vezes.

Como silos experimentais, foram usados tambores de plásticos (barricas plásticas) de 150 litros, os quais foram hermeticamente fechados após o seu enchimento. A compactação da massa foi efetuada por homens no interior do silo. Foram utilizados 27 tambores para os tratamentos e mais 9 para serem usados no periodo de adaptação dos animais.

No momento do enchimento dos silos, foi retirada uma amostra do material a ser ensilado, em cada repetição dos tratamentos, a qual foi dividida em duas porções. Uma porção foi pesada e colocada em estufa de ar forçado regulada a $65^{\circ} \mathrm{C}$ para secagem até atingir peso constante. Após a secagem e esfriamento, a amostra foi pesada para cálculo da porcentagem de matéria seca a $65^{\circ} \mathrm{C}$. Esta amostra submetida à moagem com peneira de $1 \mathrm{~mm}$ foi utilizada para a determinação do poder tampão, teor de matéria seca (MS) a $105^{\circ} \mathrm{C}$, proteína bruta (PB) e fibra em detergente neutro (FDN). A outra porção da amostra foi armazenada em freezer a $-20^{\circ} \mathrm{C}$, sendo tal material utilizado para determinação dos teores de carboidratos solúveis. Antecedendo esta 
determinação em laboratório, as amostras verdes foram moídas em liquidificador, tipo industrial, com gelo seco de gás carbônico.

O experimento foi desenvolvido obedecendo um delineamento em blocos ao acaso com 3 repetições por tratamento. Os tratamentos foram arranjados num esquema fatorial $3 \times 3$ ( 3 idades de corte e 3 tipos de forragem). Nas análises de variância e de regressão, foi utilizado o Sistema de Análise Estatística para Microcomputadores - SANEST.

A análise de variância foi realizada, conforme Tabela 1.

Tabela 1. Esquema de análise de variância das características determinadas nas silagens.

\begin{tabular}{lc}
\hline \multicolumn{1}{c}{ Causa da variação } & Graus de liberdade \\
\hline Blocos & 2 \\
Idades $(I)$ & 2 \\
Tipo de forragem $(T)$ & 2 \\
I $x$ T & 4 \\
Resíduo & 16 \\
\hline Total & 26 \\
\hline
\end{tabular}

$\mathrm{Na}$ prova de consumo voluntário e digestibilidade aparente, foram utilizados 27 ovinos machos da mesma raça, com peso médio de $22 \mathrm{~kg}$. Preliminarmente, os animais foram submetidos a exames de fezes, constatando-se a existência de verminose a qual foi combatida, utilizando-se os vermífugos Cidectin e Dectomax. Somente após a comprovação da inexistência de vermes, iniciou-se esta fase. Esta etapa do trabalho foi realizada na Estação Experimental de Nova Odessa-SP, tendo em vista que as gaiolas e os animais se encontravam na referida estação. 
Para teste, os animais foram mantidos em gaiolas individuais com coletor e separador de urina e fezes. Durante as fases do ensaio, receberam sal mineral e água à vontade.

A prova de consumo e digestibilidade compreendeu três períodos, 10 dias para adaptação dos animais às dietas e ao ambiente experimental, 10 dias para determinação do consumo voluntário (determinado pela média de ingestão dos 3 últimos dias) e 7 dias para coleta de amostras do alimento oferecido, das sobras e das fezes produzidas, conforme recomendações de Staples \& Dinusson (1951). No período de coleta de amostras, os animais receberam $100 \%$ do consumo voluntário determinado.

A amostragem das silagens foi desenvolvida durante o periodo de coleta da prova de digestibilidade. Neste sentido, amostras diárias das silagens foram retiradas e armazenadas em freezer a $-20^{\circ} \mathrm{C}$. Após 7 dias, foram misturadas as alíquotas das silagens coletadas de cada tratamento, formando uma amostra composta que foi dividida em duas porções, uma para extração de suco e outra para ser seca e moída. Na amostra de suco, foram determinados $\mathrm{opH}$ e as porcentagens de nitrogênio amoniacal e dos ácidos orgânicos. Na porção seca em estufa, foram determinadas as porcentagens de MS, PB, FDN, fibra bruta (FB) e extrato etéreo (EE). A porcentagem dos extrativos não nitrogenados (ENN) foi estimada por cálculo.

Diariamente, durante o período de coleta, foram collhidas as fezes dos animais e, imediatamente, após a pesagem, foi retirada uma amostra diária de mais ou menos $10 \%$ do total. Estas foram mantidas em freezer a $-20^{\circ} \mathrm{C}$ até o último dia de coleta. Posteriormente, as alíquotas diárias foram misturadas formando uma amostra composta, sendo retirada uma porção para secagem em estufa de ar forçado, regulada a $65^{\circ} \mathrm{C}$, até atingir peso constante. Após esfriamento e pesagem, a amostra foi submetida a moagem com peneira de $1 \mathrm{~mm}$ e devidamente acondicionada. 
Nas amostras de fezes, foram determinadas as mesmas características consideradas nas amostras secas das silagens.

\subsection{Análises laboratoriais}

As análises para determinação de $M S, P B, F B$ e EE das amostras foram realizadas, conforme a metodologia da A.O.A.C. (1975) e Goering \& Van Soest (1970), exceto para os ENN que foram determinados através de cálculo.

As determinações de FDN foram realizadas, conforme a metodologia de Goering \& Van Soest (1970).

Os teores de carboidratos solúveis foram determinados, segundo a metodologia de Deriaz (1961).

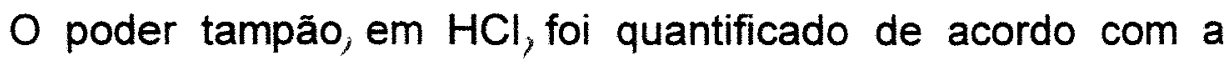
técnica utilizada por Playne \& McDonald (1966).

Os ácidos orgânicos, no suco das silagens, foram determinados, conforme o método de Wilson (1971), sendo o nitrogênio amoniacal, como porcentagem do $\mathrm{N}$ total, determinado segundo a metodologia utilizada por Tosi (1973). 


\section{RESULTADOS E DISCUSSÃO}

\subsection{Produção do capim-elefante}

\subsubsection{Produção de matéria seca}

As produções de matéria seca (MS) do capim-elefante são apresentadas na Tabela 2.

$\mathrm{Na}$ análise de variância das produções de matéria seca, foi observada diferença mínima significativa $(P<0,01)$ para idade. $O$ coeficiente de variação encontrado foi de $12,90 \%$.

O desdobramento do efeito de idade, através de análise de regressão, mostrou que a variação da produção de matéria seca pode ser representada por uma curva linear $(P<0,05)$, conforme equação: $y=-4973,6829+164,4778 x$, com $R^{2}=0,9823$. A variação ocorrida na produção de matéria seca é ilustrada na Figura 1.

Os resultados encontrados foram inferiores aos de Lavezzo et al. (1990), 14600 e $15800 \mathrm{~kg} / \mathrm{ha}$, quando avaliaram as produções de dois cultivares de capim-elefante, Mineiro e Vruckwona, respectivamente, aos 75 dias de desenvolvimento. Por outro lado, a produção do capim aos 84 dias, foi superior à de Barbosa et al. (1995), 6627 kg/ha, quandolavaliaram o capimelefante, cultivar Vruckwona, aos 90 dias de desenvolvimento. Esses resultados podem ser explicados pelo período do ano e a fertilidade do solo de cada ensaio. 
Tabela 2. Produção média de matéria seca do capim-elefante, cultivar Guaçu, aos 56,70 e 84 dias de desenvolvimento (média de 5 repetições)

\begin{tabular}{cc}
\hline Idade de corte & $\mathrm{kg} / \mathrm{ha}$ \\
\hline 56 & 4238 \\
70 & 6540 \\
84 & 8842 \\
\hline
\end{tabular}

Como ilustra a Figura 1, a produção de matéria aumentou com a maturidade da planta, estando de acordo com os resultados, respectivamente, de Pedreira \& Boin (1969); Andrade \& Gomide (1971) e de Yeo (1977), quando avaliaram a produção do capim-elefante (Napier, Taiwan A-146 e Napier), de 21 a 210, 28 a 196 e de 40 a 160 dias de desenvolvimento, cujos resultados variaram de 2700 a 27100; 5750 a 34430 e de 1166 a $14476 \mathrm{~kg}$ de MS/ha.

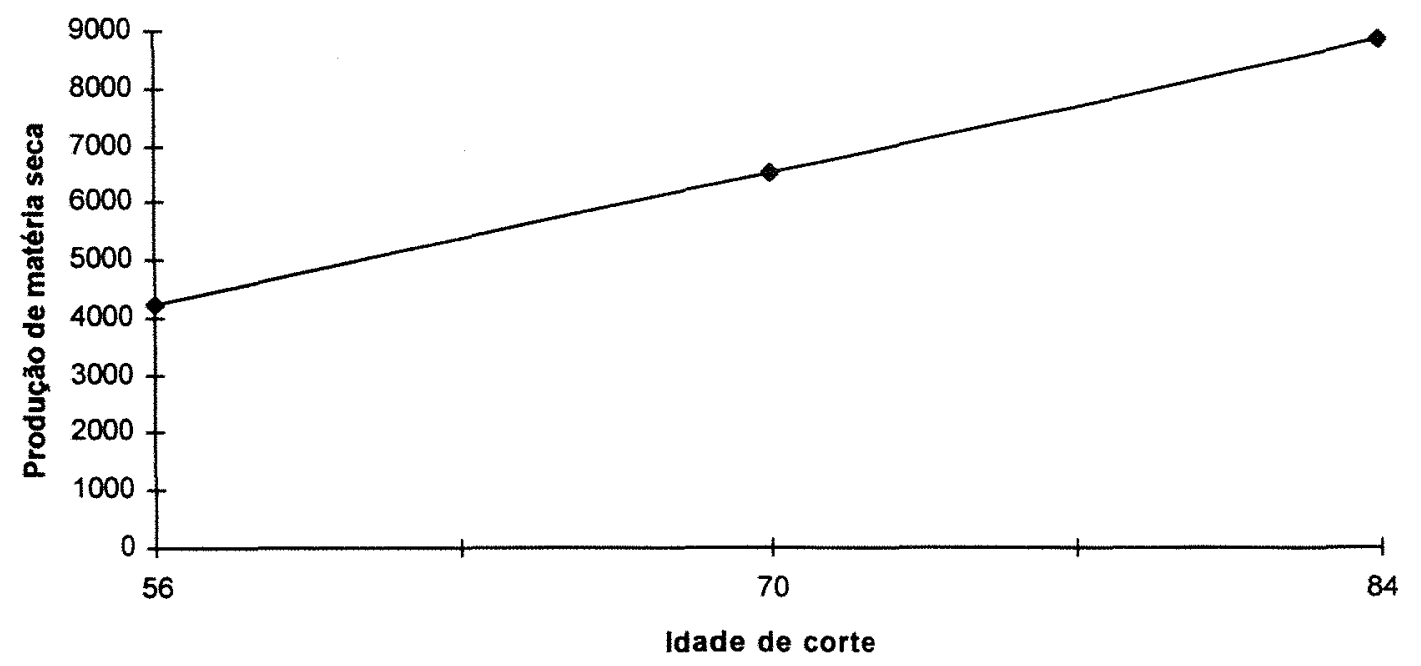

Figura 1. Variação da produção de matéria seca, em $\mathrm{kg} / \mathrm{ha}$, do capim-elefante, cultivar Guaçu, aos 56, 70 e 84 dias de desenvolvimento. 


\subsubsection{Porcentagens de haste, lâmina e material morto da forragem}

As porcentagens de haste, lâmina e material morto da forragem do capim-elefante são apresentadas na Tabela 3.

$\mathrm{Na}$ análise de variância das porcentagens de haste, lâmina e material morto, foi observada diferença mínima significativa $(P<0,05)$ para idade. Os coeficientes de variação encontrados foram $6,14 \%, 7,95 \%$ e 30,50\%, respectivamente.

Tabela 3. Porcentagens de haste, lâmina e material morto da forragem do capim-elefante, cultivar Guaçu, aos 56,70 e 84 dias de desenvolvimento.

\begin{tabular}{cccc}
\hline Idade de corte & Haste $^{1}$ & Lâmina $^{1}$ & Material morto $^{1}$ \\
\hline 56 & 44,37 & 52,01 & 3,62 \\
70 & 48,32 & 45,43 & 6,25 \\
84 & 52,27 & 38,85 & 8,88 \\
\hline
\end{tabular}

na base seca

O desdobramento do efeito de idade, através de análise de regressão, mostrou que as variaçōes das porcentagens de matéria seca de haste, lâmina e material morto podem ser representadas por curvas lineares $(P<0,05)$, conforme as equações: $y=28,5610+0,2822 x$, com $R^{2}=0,9212$; $y=78,3270-0,4699 x$, com $R^{2}=0,9610$ e $y=-6,8880+0,1877 x$, com $R^{2}=0,9958$, respectivamente. As variações ocorridas nas porcentagens de haste, lâmina e material morto da forragem são ilustradas na Figura 2.

Os valores encontrados para haste e lâmina aos 70 dias são os que mais se aproximam da relação haste/folha, $1: 1$, recomendada por Lavezzo (1993) para a ensilagem de capim-elefante. Na idade de 56 dias, os 
resultados encontrados foram próximos aos valores de Silveira (1970), 53,99\% e $46,01 \%$, para folha e haste, respectivamente, quando avaliou a relação haste/folha do capim-elefante, variedade Napier, aos 51 dias de desenvolvimento. Este aumento da participação da haste na matéria seca do capim com a maturidade da planta acontece também com outras espécies forrageiras, conforme foi constatado por Pinto et al. (1994), quando observaram que as produções de tecidos foliar e caulinar cresceram, enquanto a relação folha/caule diminuiu com o avanço da idade da planta, na avaliação dos capins Andropogon, Guiné e Setária de 14 a 70 dias de desenvolvimento.

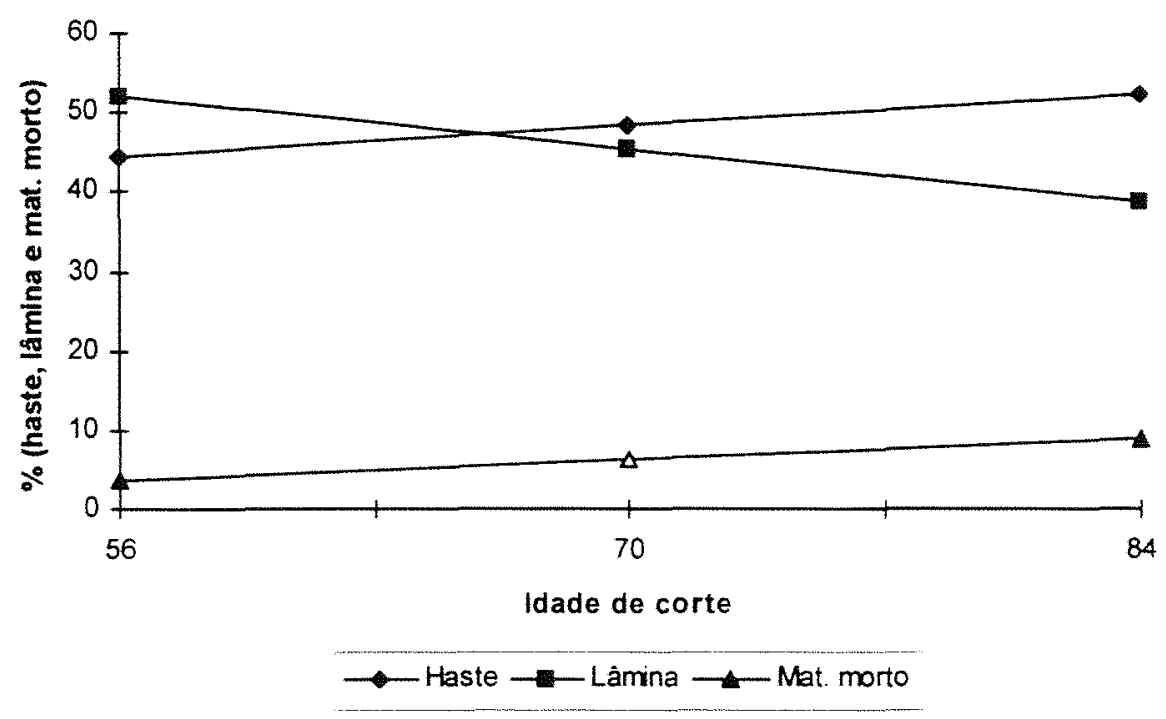

Figura 2. Variações das porcentagens de matéria seca de haste, lâmina e material morto na forragem do capim-elefante, cultivar Guaçu, aos 56,70 e 84 dias de desenvolvimento.

Pela ilustração da Figura 2, percebe-se que as porcentagens de haste e material morto cresceram com a maturidade da planta, enquanto que a porcentagem de lâmina diminuiu. Esta redução da participação da lâmina, na composição da matéria seca, faz com que o valor nutritivo do capim- 
elefante diminua com a maturidade da planta, confirmando os resultados de Pedreira \& Boin (1969), de Gennari \& Mattos (1977) e de Yeo (1977), quando avaliaram o valor nutritivo do capim-elefante, cultivar Napier, de 21 a 210, de 42 a 84 e de 40 a 160 dias de desenvolvimento, respectivamente.

\subsection{Efeito do emurchecimento na composição das forragens utilizadas}

\subsubsection{Porcentagem de matéria seca}

As porcentagens de matéria seca das forragens são apresentadas na Tabela 4 .

$\mathrm{Na}$ análise de variância dos teores de matéria seca, foi observada diferença mínima significativa $(P<0,01)$ para idade e tipo de forragem, havendo interação entre idade e tipo de forragem $(P<0,01)$. coeficiente de variação encontrado foi de $2,05 \%$.

$O$ desdobramento de tipos de forragem, dentro de idade de corte, mostrou que, na idade de 56 dias, o teor de $31.92 \%$ de matéria seca da forragem emurchecida triturada foi superior $(P<0,05)$ às porcentagens das demais forragens, sendo a da forragem emurchecida inteira $(30.16 \%)$ maior que a da forragem fresca $(21,20 \%)$. Nesta idade, o emurchecimento com a planta triturada foi mais eficiente na elevação do teor de matéria seca do que o emurchecimento com a planta inteira, podendo este ter sido influenciado pela baixa perda de umidade da planta na camada inferior.

$\mathrm{Na}$ idade de 70 dias, não houve diferença significativa $(P>0,05)$ entre as porcentagens de matéria seca das forragens emurchecida inteira $(30,25 \%)$ e emurchecida triturada $(30,41 \%)$ as quais foram superiores $(P<0,05) ` a$ da forragem fresca $(22,58 \%)$. Nesta idade, o emurchecimento com a planta inteira e com a planta triturada tiveram a mesma eficiência na elevação da porcentagem de matéria seca da forragem. 
Tabela 4. Porcentagem de matéria seca das forragens fresca e emurchecidas (inteira e triturada) do capim-elefante, cultivar Guaçu, aos 56,70 e 84 dias de desenvolvimento.

\begin{tabular}{ccccc}
\hline & \multicolumn{3}{c}{ Idade de corte } & \multirow{2}{*}{ Média } \\
\cline { 2 - 4 } Tipo de forragem & 56 & 70 & 84 & \\
\hline $\mathrm{FF}^{1}$ & $21,20 \mathrm{c}$ & $22,58 \mathrm{~b}$ & $23,75 \mathrm{c}$ & 22,51 \\
$\mathrm{El}^{2}$ & $30,16 \mathrm{~b}$ & $30,25 \mathrm{a}$ & $34,21 \mathrm{a}$ & 31,54 \\
& & & & \\
$\mathrm{ET}^{3}$ & $31,92 \mathrm{a}$ & $30,41 \mathrm{a}$ & $28,01 \mathrm{~b}$ & 30,11 \\
\hline Média & 27,76 & 27,75 & 28,66 & \\
\hline
\end{tabular}

Forragem fresca', Emurchecida inteira ${ }^{2}$, Emurchecida triturada ${ }^{3}$.

Médias seguidas de letras distintas, na coluna, diferem entre si pelo teste de Tukey $(P<0,05)$.

$\mathrm{Na}$ idade de 84 dias, o emurchecimento com a planta inteira $(34,21 \%$ de $M S)$ foi mais eficiente $(P<0,05)$ do que com a planta triturada $(28,01 \%$ de $M S)$, os quais proporcionaram teores de matéria seca superiores ao da forragem fresca $(23,75 \%)$. Além disso, a forragem emurchecida inteira foi a última a ser recolhida do campo permanecendo mais tempo exposta ao sol do que àquelas das idades de 56 e 70 dias. Por outro lado, a forragem, neste estádio de maturidade, apresenta maior participação de haste as quais ficam mais finamente trituradas do que as folhas, dificultando a aeração da massa e conseqüentemente a perda de umidade.

De maneira geral, pode-se dizer que a eficiência do emurchecimento com a planta inteira foi semelhante ao da planta triturada.

A porcentagem de matéria seca da forragem fresca, aos 56 dias, foi superior ao valor de Andrade \& Gomide (1971), 16,2\%, quando cortaram o capim-elefante, cultivar Taiwan A-146, na mesma idade. Na idade 
de 70 dias, a porcentagem de matéria seca foi superior ao valor levantado por Vilela (1994), 18,6\%, para o capim-elefante na mesma idade. No caso da forragem aos 84 dias, o teor de matéria seca encontrado foi superior ao resultado observado por Andrade \& Gomide (1971), 21,3\%, para o capimelefante, cultivar Taiwan A-146, na mesma idade, e aos valores de Corsi (1972), quando avaliou as porcentagens de matéria seca do capim-elefante, cultivar Napier, aos 90 dias em diferentes alturas de corte, as quais variaram de 17,23 a $21,46 \%$. Os resultados encontrados no presente trabalho podem estar associados à época do ano em que foi realizado o experimento.

Os resultados encontrados, para as forragens emurchecida inteira e emurchecida triturada em todas as idades, foram, respectivamente, inferiores e superiores aos valores de Tosi et al. (1995), 41,3\% e 18,3\%, quando trabalharam com o capim-elefante, cultivar Mott, aos 72 dias de desenvolvimento, fazendo a desidratação da forragem à sombra. Ainda quanto à forragem emurchecida triturada, os resultados foram inferiores ao de Vilela \& Wilkinson (1987), 40,37\%, quando submeteram o capim-elefante triturado ao emurchecimento, no próprio local da capineira, durante 6 horas. No caso da forragem emurchecida inteira, os resultados encontrados, em todas as idades, foram superiores aos valores de Tosi et al. (1983b), 20,87\%, quando realizaram o emurchecimento durante 8 horas, e 22,39\%, para 12 horas e 30 minutos, utilizando o capim-elefante, cultivar Taiwan A-148, aos 55 dias de desenvolvimento nos dois tratamentos.

O desdobramento do efeito de idade, dentro de tipos de forragem, através de análise de regressão, mostrou que as variações dos teores de matéria seca das forragens fresca, emurchecida inteira e emurchecida triturada podem ser representadas por curvas lineares $(P<0,05)$, conforme as equações: $y=16,1172+0,0913 x$, com $R^{2}=0,9979 ; y=21,4117+$ $0,1446 x$, com $R^{2}=0,7667$ e $y=39,8811-0,1395 x$, com $R^{2}=0,9831$, 
respectivamente. As variações ocorridas nos teores de matéria seca são ilustradas na Figura 3.

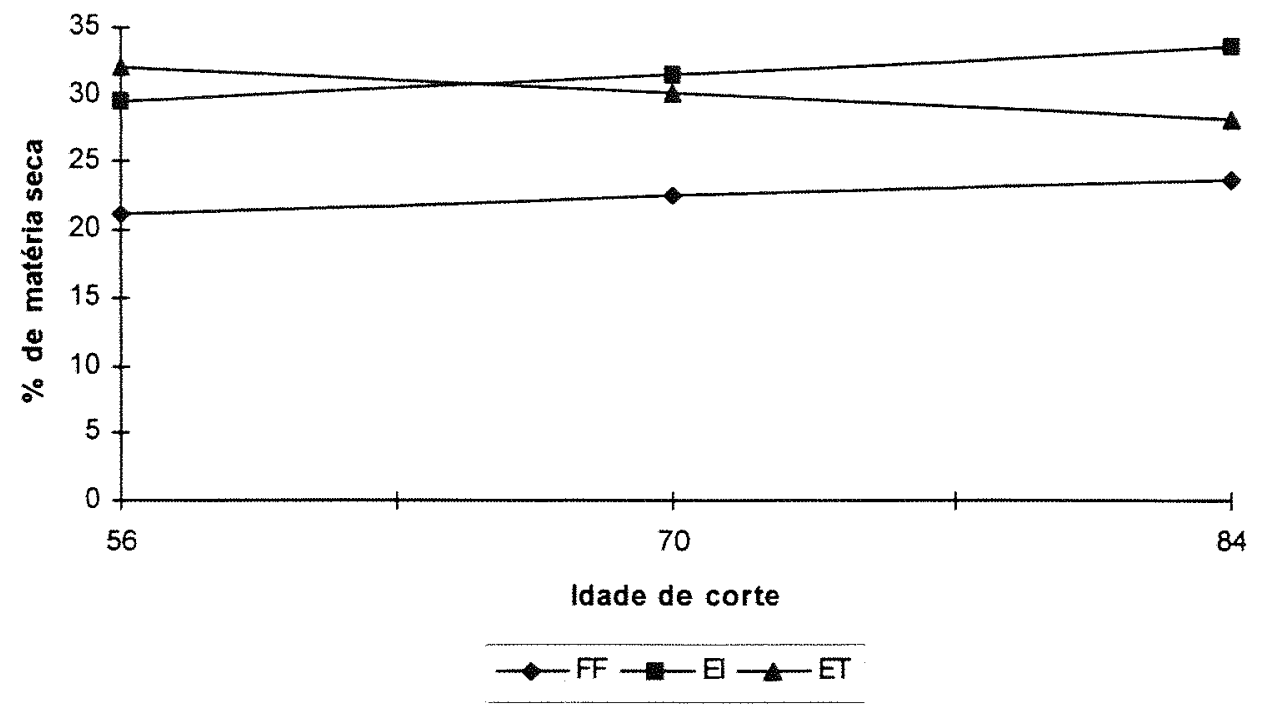

Figura 3. Variações das porcentagens de matéria seca das forragens fresca e emurchecidas (inteira e triturada) do capim-elefante, cultivar Guaçu, aos 56,70 e 84 dias de desenvolvimento.

Pela ilustração da Figura 3, observa-se que os teores de matéria seca da forragem fresca aumentaram com a maturidade da planta, confirmando os resultados de Azevedo et al. (1986) e Andrade \& Gomide (1971), quando determinaram a porcentagem de matéria seca do capimelefante, cultivar Cameron de 30 a 150 dias de desenvolvimento e do cultivar Taiwan A-146 de 28 a 196 dias, respectivamente. Os resultados encontrados com o emurchecimento estão de acordo com os valores de 28 a $34 \%$ recomendados por McCulloug (1977). Com exceção da forragem emurchecida triturada $(28,01 \%$ de $\mathrm{MS})$ aos 84 dias de desenvolvimento, as demais forragens emurchecidas apresentaram teores de matéria seca acima dos $30 \%$ recomendados por Gordon (1967) e Whittenbury et al. (1967). 
A porcentagem de matéria seca da forragem emurchecida inteira aumentou com o avanço da idade da planta, embora a participação de haste tenha aumentado. Este acréscimo da matéria seca deve estar relacionado ao maior tempo de exposição ao sol das forragens mais velhas, considerando que a trituração do material começou do capim de menor idade para o de maior idade. Embora o corte do capim, no dia anterior à trituração, tenha começado nesta ordem, o tempo gasto nesta operação foi pequeno de forma que a partir das nove horas todas as forragens já se encontravam expostas ao sol. Já o tempo gasto na operação de trituração e enchimento dos silos de cada tipo de forragem, a partir das nove horas do dia seguinte, foi superior ao seu respectivo tempo de corte, fazendo com que as forragens das idades seguintes ( 70 e 84 dias) ficassem mais tempo expostas ao sol. Este descompasso de tempo fez com que a forragem do capim com 84 dias fosse recolhida do campo para trituração apenas a partir das treze horas.

A queda na porcentagem de matéria seca da forragem emurchecida triturada nas idades de 70 e 84 dias deve estar relacionada à maior participação de haste as quais ficam mais finamente trituradas do que as folhas, dificultando a aeração da massa e conseqüentemente a perda de umidade. Além disso, em torno do meio dia ocorreu nebulosidade, o que de certa forma dificultou a perda de umidade.

\subsubsection{Porcentagem de proteina bruta}

As porcentagens de proteina bruta das forragens são apresentadas na Tabela 5 .

$\mathrm{Na}$ análise de variância dos teores de proteína bruta, foi observada diferença mínima significativa $(P<0,01)$ para idade e tipo de forragem, havendo interação entre idade e tipo de forragem $(P<0,01)$. $O$ coeficiente de variação encontrado foi de $2,26 \%$. 
Tabela 5. Porcentagem de proteina bruta das forragens fresca e emurchecidas (inteira e triturada) do capim-elefante, cultivar Guaçu, aos 56, 70 e 84 dias de desenvolvimento.

Idade de corte

\begin{tabular}{ccccc} 
Tipo de forragem & 56 & 70 & 84 & Média \\
\cline { 2 - 4 } $\mathrm{FF}^{1}$ & $10,42 \mathrm{~b}$ & $7,48 \mathrm{c}$ & $6,91 \mathrm{~b}$ & 8,27 \\
$\mathrm{El}^{2}$ & $10,74 \mathrm{ab}$ & $9,03 \mathrm{a}$ & $8,12 \mathrm{a}$ & 9,30 \\
& & & & \\
$\mathrm{ET}^{3}$ & $10,97 \mathrm{a}$ & $8,40 \mathrm{~b}$ & $7,74 \mathrm{a}$ & 9,04 \\
\hline Média & 10,71 & 8,30 & 7,59 &
\end{tabular}

Forragem fresca, Emurchecida inteira ${ }^{2}$, Emurchecida triturada $^{3}$.

Médias seguidas de letras distintas, na coluna, diferem entre si pelo teste de Tukey $(P<0,05)$.

O desdobramento de tipos de forragem, dentro de idade de corte, mostrou que, na idade de 56 dias, o teor de proteína $(10,97 \%)$ da forragem emurchecida triturada foi maior $(P<0,05)$ do que 0 da forragem fresca $(10,42 \%)$ não havendo diferença mínima significativa $(P>0,05)$ entre o teor desta primeira e o da forragem emurchecida inteira $(10,74 \%)$. Por outro lado, o teor desta última foi semelhante ao da forragem fresca $(P>0,05)$.

$\mathrm{Na}$ idade de 70 dias, o teor de proteína bruta da forragem emurchecida inteira $(9,03 \%)$ foi superior $(P<0,05)$ ao da forragem emurchecida triturada $(8,40 \%)$, sendo este último superior $(P<0,05)$ ao teor da forragem fresca $(7,48 \%)$.

$\mathrm{Na}$ idade de 84 dias, as forragens emurchecidas, inteira e triturada, não apresentaram diferença significativa $(P>0,05)$ nos teores de proteína bruta, $8,12 \%$ e $7,74 \%$, respectivamente. Por outro lado, foram superiores $(P<0,05)$ ao da forragem fresca $(6,91 \%)$. 
As diferenças verificadas nas porcentagens de proteina, dentro de cada idade, devem estar associadas ao efeito de concentração devido à perda de umidade da forragem durante o processo de emurchecimento. Além disso, acredita-se que tenha havido perdas de proteina bruta via extravasamento celular, principalmente nas idades de 70 e 84 dias, devido à maior porcentagem de hastes na forragem, as quais ficam mais dilaceradas do que as folhas quando submetidas à trituração. Isso explicaria a queda no teor de proteina da forragem emurchecida triturada nas referidas idades.

A porcentagem de proteína bruta encontrada para a forragem fresca, aos 56 dias de desenvolvimento, foi próxima ao valor de Andrade (1995), 10,46\%, quando cortou o capim-elefante, cultivar Guaçu, aos 62 dias de desenvolvimento e superior ao de Yeo (1977), 8,12\%, quando cortou o capim-elefante, cultivar Napier, aos 40 dias de desenvolvimento. A porcentagem encontrada aos 70 dias foi inferior ao valor de Alberto et al. (1993), 12,22\%,quandocortaramo capim-elefante, cultivar Cameron, aos 75 dias de desenvolvimento. Já na idade de 84 dias, o resultado encontrado foi superior ao de Andrade \& Gomide (1971), 4,8\%, para o capim-elefante, cultivar Taiwan A-146, cortado na mesma idade.

O desdobramento do efeito de idade, dentro de tipos de forragem, através de análise de regressão, mostrou que as variações dos teores de proteína bruta das forragens fresca, emurchecida inteira e emurchecida triturada podem ser representadas por curvas lineares $(P<0,05)$, conforme as equações: $y=17,0272-0,1251 x$, com $R^{2}=0,8670 ; y=15,8456$. $0,0936 x$, com $R^{2}=0,9708$ e $y=17,1044-0,1152 x$, com $R^{2}=0,8951$, respectivamente. As variações ocorridas nos teores de proteína bruta são ilustradas na Figura 4.

Pelo que ilustra a Figura 4, como era esperado, o teor de proteina bruta diminuiu com o avanço da idade do capim, concordando com os resultados encontrados por Silveira et al. (1974), quando avaliaram o efeito da 
maturidade da planta sobre a composição bromatológica do capim-elefante, cultivar Napier.

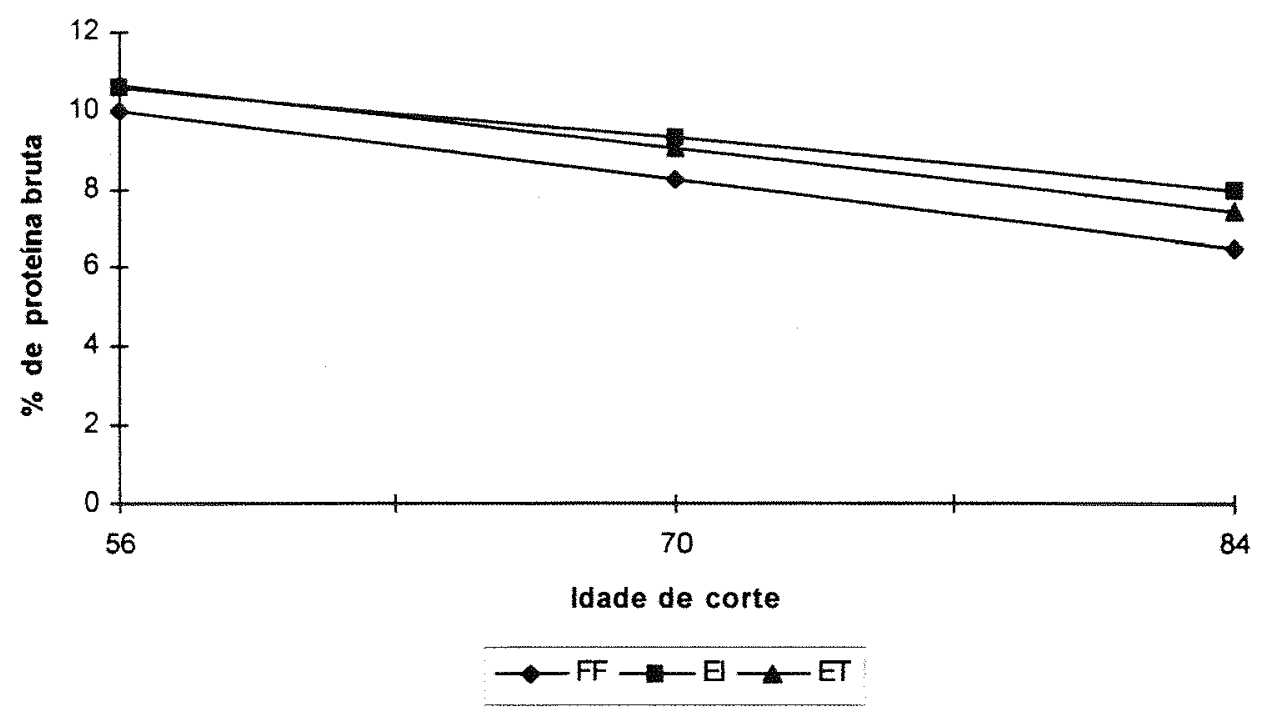

Figura 4. Variações das porcentagens de proteína bruta das forragens fresca e emurchecidas (inteira e triturada) do capim-elefante, cultivar Guaçu, aos 56,70 e 84 dias de desenvolvimento.

\subsubsection{Porcentagem de fibra em detergente neutro}

As porcentagens de fibra em detergente neutro (FDN) das forragens são apresentadas na Tabela 6.

$\mathrm{Na}$ análise de variância dos teores de fibra em detergente neutro, foi observada diferença minima significativa $(P<0,01)$ para idade e tipo de forragem, havendo interação entre idade e tipo de forragem $(P<0,05)$. $O$ coeficiente de variação encontrado foi de $1,25 \%$.

$O$ desdobramento de tipos de forragem, dentro de idade de corte, mostrou que, nas idades de 56 e 84 dias, os tipos de forragem, dentro de cada idade, não apresentaram diferença significativa no teor de fibra em 
detergente neutro $(P>0,05)$. Na idade de 70 dias, a forragem emurchecida triturada apresentou maior $(P<0,05)$ teor de FDN $(77,86 \%)$ do que as forragens fresca e emurchecida inteira, $74,39 \%$ e $74,05 \%$, respectivamente. $O$ resultado para a forragem emurchecida inteira não foi o esperado, uma vez que deveria ter sido elevado pelo efeito de concentração por causa da perda de umidade.

Tabela 6. Porcentagem de fibra em detergente neutro das forragens fresca e emurchecidas (inteira e triturada) do capim-elefante, cultivar Guaçu, aos 56,70 e 84 dias de desenvolvimento.

Idade de corte

\begin{tabular}{llll}
\cline { 2 - 3 } Tipo de forragem & 56 & 70 & 84
\end{tabular}

\begin{tabular}{|c|c|c|c|}
\hline $\mathrm{FF}^{1}$ & $73,16 \mathrm{a}$ & $74,39 b$ & 75,77 a \\
\hline$E l^{2}$ & $74,72 \mathrm{a}$ & $74,05 \mathrm{~b}$ & $76,37 \mathrm{a}$ \\
\hline
\end{tabular}

\begin{tabular}{cllll}
$\mathrm{ET}^{3}$ & $74,46 \mathrm{a}$ & $77,86 \mathrm{a}$ & $77,52 \mathrm{a}$ & 76,61 \\
\hline Média & 74,11 & 75,43 & 76,55
\end{tabular}

Forragem fresca, Emurchecida inteira ${ }^{2}$, Emurchecida triturada. ${ }^{3}$.

Médias seguidas de letras distintas, na coluna, diferem entre si pelo teste de Tukey $(P<0,05)$.

Os valores encontrados foram superiores ao de Henrique (1990), 69,61\%, quando cortou o capim-elefante, cultivar Guaçu, aos 63 dias de desenvolvimento; aos de Alberto et al. (1993), 72,03\% e 69,02\%, quando utilizaram o capim-elefante, cultivar Cameron, fresco e emurchecido, respectivamente, aos 75 dias de desenvolvimento e aos valores de Vilela et al. (1990), 62,21\% e 67,31\%, quando submeteram o capim-elefante, cultivar 
Mineiro, ao emurchecimento durante 6 e 30 horas, respectivamente, o qual apresentava de 56 a 63 dias de desenvolvimento. Esperava-se uma maior porcentagem de FDN para as forragens com maior teor de matéria seca em virtude do efeito de concentração como aconteceu com o trabalho de Vilela et al. (1990) referido anteriormente.

O desdobramento do efeito de idade, dentro de tipos de forragem, através de análise de regressão, mostrou que a variação dos teores de FDN da forragem fresca pode ser representada por uma curva linear $(P<0,05)$, conforme equação: $y=67,9117+0,0932 x$, com $R^{2}=0,9989$. Por outro lado, as variações dos teores de FDN das forragens emurchecidas, inteira e triturada, podem ser representadas por curvas quadráticas $(P<0,05)$, conforme as equações: $y=107,4300-1,0126 x+0,0076 x^{2}$, com $R^{2}=1,0000 e$ $y=23,4433+1,4452 x-0,0095 x^{2}$, com $R^{2}=1,0000$, respectivamente. As variações dos teores de FDN são ilustradas na Figura 5.

Pela ilustração da Figura 5, como era esperado, observa-se que o teor de FDN da forragem fresca aumentou com a maturidade da planta, o que foi constatado por Yeo (1977), quando avaliou o capim-elefante, cultivar Napier, de 40 a 160 dias de desenvolvimento. Esperava-se que as porcentagens de FDN aumentassem com a elevação do teor de matéria seca das forragens emurchecidas e vice-versa, o que não aconteceu. não havendo justificativa coerente para tal fato. 


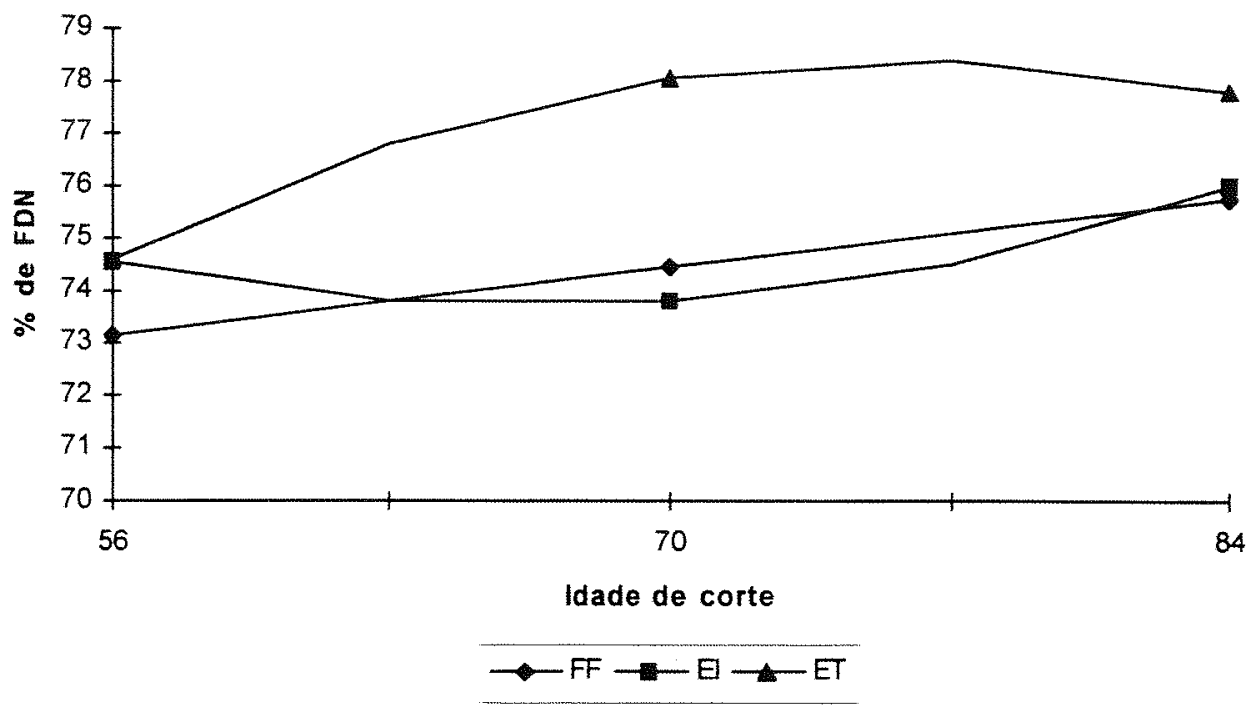

Figura 5. Variações das porcentagens de fibra em detergente neutro das forragens fresca e emurchecidas (inteira e triturada) do capimelefante, cultivar Guaçu, aos 56, 70 e 84 dias de desenvolvimento.

\subsubsection{Porcentagem de carboidratos solúveis}

As porcentagens de carboidratos solúveis das forragens são apresentadas na Tabela 7 .

$\mathrm{Na}$ análise de variância dos teores de carboidratos solúveis, foi observada diferença mínima significativa $(P<0,01)$ para idade e tipo de forragem, havendo interação entre idade e tipo de forragem $(P<0,05)$. $O$ coeficiente de variação encontrado foi de $9,06 \%$.

$O$ desdobramento de tipos de forragem, dentro de idade de corte, mostrou que, na idade de 56 dias, as forragens fresca $(8,70 \%)$, emurchecida inteira $(7,18 \%)$ e emurchecida triturada $(8,08 \%)$ não apresentaram diferenças significativas $(P>0,05)$ entre si.

$\mathrm{Na}$ idade de 70 dias, 0 teor de carboidratos solúveis da forragem fresca $(10,98 \%)$ foi superior $(P<0,05)$ ao teor das demais forragens. 
Por outro lado, não foi constatada diferença significativa $(P>0,05)$ entre os teores das forragens emurchecidas, inteira e triturada, 6,60\% e 7,39\%, respectivamente. O mesmo ocorreu na idade de 84 dias, sendo as porcentagens de carboidratos solúveis das forragens, fresca, emurchecida inteira e emurchecida triturada, de $12,63 \%, 9,77 \%$ e $9,43 \%$, respectivamente.

Tabela 7. Porcentagem de carboidratos solúveis das forragens fresca e emurchecidas (inteira e triturada) do capim-elefante, cultivar Guaçu, aos 56, 70 e 84 dias de desenvolvimento.

\begin{tabular}{|c|c|c|c|c|}
\hline \multirow[b]{2}{*}{ Tipo de forragem } & \multicolumn{3}{|c|}{ Idade de corte } & \multirow[b]{2}{*}{ Média } \\
\hline & 56 & 70 & 84 & \\
\hline $\mathrm{FF}^{1}$ & $8,70 a$ & $10,98 \mathrm{a}$ & $12,63 \mathrm{a}$ & 10,77 \\
\hline$\left.E\right|^{2}$ & $7,18 \mathrm{a}$ & $6,60 \mathrm{~b}$ & $9,77 b$ & 7,85 \\
\hline$E T^{3}$ & $8,08 \mathrm{a}$ & $7,39 \mathrm{~b}$ & $9,43 b$ & 8,30 \\
\hline Média & 7,99 & 8,32 & 10,61 & \\
\hline
\end{tabular}

Forragem fresca', Emurchecida inteira ${ }^{2}$, Emurchecida triturada ${ }^{3}$.

Médias seguidas de letras distintas, na coluna, diferem entre si pelo teste de Tukey $(P<0,05)$.

A maior redução dos teores de carboidratos solúveis nas forragens emurchecidas é explicada pela perda por respiração celular. Estas perdas foram maiores na forragem emurchecida inteira devido ao maior tempo de exposição do material ao meio ambiente. No caso da forragem emurchecida triturada, além das perdas por respiração, ocorre também maior consumo de carboidratos devido à fermentação dos microorganismos aeróbios. Na idade de 56 dias, estas perdas foram menores não apresentando diferença 
significativa. Esta menor perda deve ser atribuída ao menor tempo de exposição do material ao meio ambiente pelas razões já discutidas. Na idade de 84 dias, a porcentagem de carboidratos solúveis da forragem emurchecida inteira, embora não significativa, foi maior do que à da forragem triturada. Esta diferença é explicada pelo efeito de concentração, considerando que a forragem emurchecida inteira apresentou maior teor de matéria seca, conforme Tabela 4. Este efeito de concentração não é percebido nos demais casos devido à ocorrência das perdas já referidas.

Por outro lado, os valores encontrados para a forragem fresca foram superiores ao observado por Peres (1997), 7,6\%, quando trabalhou com capim-elefante, cultivar Roxo, aos 72 dias de desenvolvimento. No caso da forragem emurchecida inteira, os resultados encontrados foram inferiores aos de Gutierrez \& Faria (1976), os quais variaram de $16,44 \%$ a $11,89 \%$, quando o capim-elefante, cultivar Taiwan A-148, foi submetido ao sol durante $0,2,4$ e 6 horas. No caso da forragem emurchecida triturada, os valores encontrados foram superiores ao de Vilela \& Wilkinson (1987), 3,17\%, quando submeteram o capim-elefante com 60 dias de desenvolvimento ao emurchecimento durante 30 horas e ao de Tosi et al. (1995), 1,6\%, quando utilizaram o capim-elefante anão, cultivar Mott, aos 72 dias de desenvolvimento, fazendo a desidratação à sombra durante 30 horas.

De uma maneira geral , o emurchecimento causa redução nos teores de carboidratos solúveis da forragem. Berto et al. (1997) verificaram uma redução de $17,9 \%$ para $11,6 \%$ no teor de carboidratos solúveis, quando utilizaram a aveia com 66 dias do plantio, submetendo-a ao emurchecimento durante 26 horas. Outros trabalhos têm constatado queda na porcentagem de carboidratos solúveis quando lançaram mão da prática do emurchecimento (Tosi et al., 1983b; Machado Filho et al., 1986 e Lavezzo et al., 1990).

A redução dos teores de carboidratos solúveis nas forragens emurchecidas não influenciou a fermentação láctica, considerando os baixos 
níveis de $\mathrm{pH}$, ácido butírico e nitrogênio amoniacal registrados, conforme Tabelas 11,15 e 16, os quais caracterizam silagens de boa qualidade.

O desdobramento do efeito de idade, dentro de tipos de forragem, através de análise de regressão, mostrou que a variação dos teores de carboidratos solúveis da forragem fresca pode ser representada por uma curva linear $(P<0,05)$, conforme equação: $y=0,9461+0,1404 x$, com $R^{2}=0,9919$. Por outro lado, as variações dos teores de carboidratos solúveis das forragens emurchecidas, inteira e triturada, podem ser representadas por curvas quadráticas $(P<0,05)$, conforme as equações: $y=47,1633-1,2515 x+$ $0,0096 x^{2}$, com $R^{2}=1,000$ e $y=38,1733-0,9278 x+0,0070 x^{2}$, com $R^{2}=1,000$, respectivamente. As variações dos teores de carboidratos solúveis são ilustradas na Figura 6.

Pela ilustração da Figura 6, observa-se que os teores de carboidratos solúveis aumentaram com a maturidade da planta, confirmando os resultados de Andrade \& Gomide (1971), 8,6\% a 11,9\%, quando determinaram a variação de carboidratos solúveis do capim-elefante, cultivar Taiwan A-146, de 28 a 196 dias de desenvolvimento. Embora atingindo menores niveis de carboidratos solúveis, as forragens emurchecidas acompanharam a tendência de ascensão com a maturidade da planta observada para a forragem fresca. Faria (1971) constatou redução na porcentagem de carboidratos solúveis de forragens, fresca e emurchecida, com a maturidade da planta, quando cortou 0 capim-elefante, cultivar Napier, aos 51, 86 e 121 dias de desenvolvimento, registrando, respectivamente, valores de $14,3 \%, 12,05 \%$ e $8,97 \%$ para a planta fresca e de $11,78 \%, 11,71 \%$ e $6,85 \%$ para a planta emurchecida. 


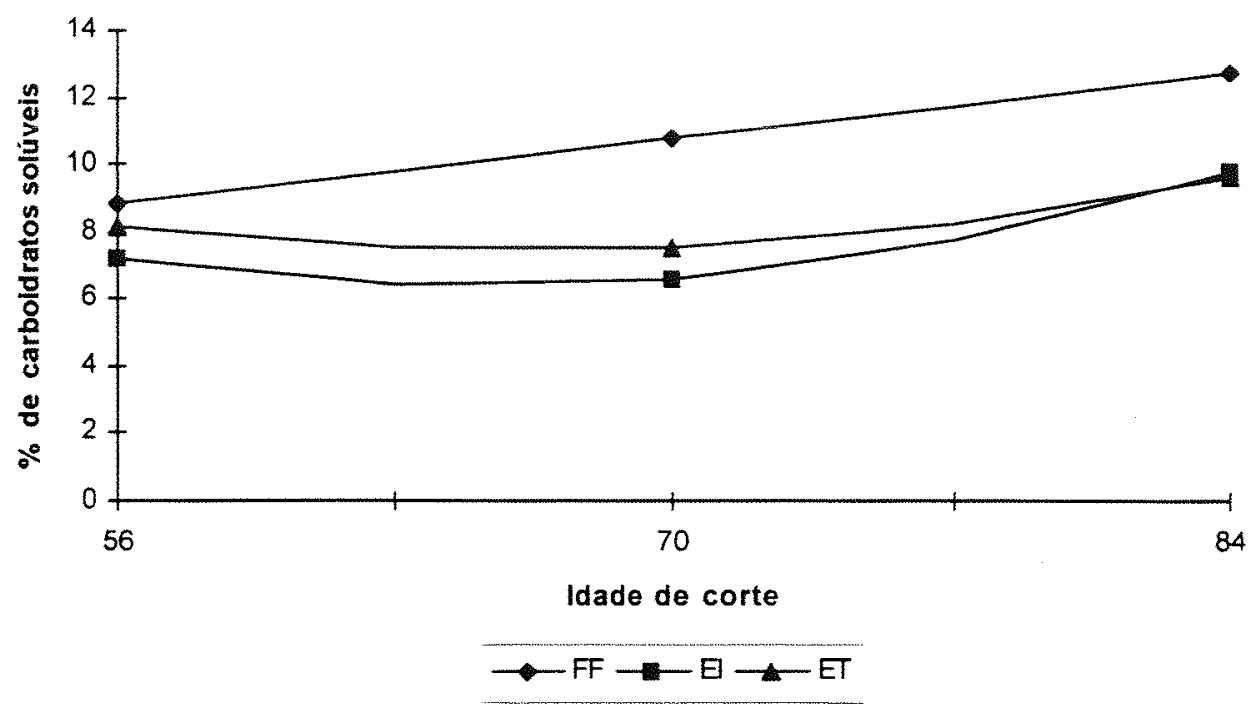

Figura 6. Variações das porcentagens de carboidratos solúveis das forragens fresca e emurchecidas (inteira e triturada) do capim-elefante, cultivar Guaçu, aos 56, 70 e 84 dias de desenvolvimento.

\subsubsection{Poder tampão das forragens}

Os valores de poder tampão das forragens são apresentados na Tabela 8.

$\mathrm{Na}$ análise de variância dos valores de poder tampão, foi observada diferença mínima significativa $(P<0,01)$ para idade e tipo de forragem, havendo interação entre idade e tipo de forragem $(P<0,01)$. $O$ coeficiente de variação encontrado foi de $2,22 \%$.

$O$ desdobramento de tipos de forragem, dentro de idade de corte, mostrou que, na idade de 56 dias, as forragens fresca, emurchecida inteira e emurchecida triturada não apresentaram diferenças significativas ( $P>0,05)$, cujos valores do poder tampão foram 19,77, 19,56 e 19,57 e.mg de $\mathrm{HCl} / 100 \mathrm{~g}$ de MS, respectivamente. 
$\mathrm{Na}$ idade de 70 dias, a forragem emurchecida inteira $(18,27$ e.mg de $\mathrm{HCl} / 100 \mathrm{~g} M S$ ) apresentou maior poder tampão $(P<0,05)$ do que as forragens fresca $(16,08)$ e emurchecida triturada $(16,16)$, sendo que estas últimas não apresentaram diferença significativa entre si $(P>0,05)$.

Tabela 8. Valores de poder tampão (em e.mg de $\mathrm{HCl} / 100 \mathrm{~g}$ de MS) das forragens fresca e emurchecidas (inteira e triturada) do capimelefante, cultivar Guaçu, aos 56, 70 e 84 dias de desenvolvimento.

\begin{tabular}{ccccc}
\hline & \multicolumn{3}{c}{ Idade de corte } & \multirow{2}{*}{ Média } \\
\cline { 2 - 4 } Tipo de forragem & 56 & 70 & 84 & 17,13 \\
$\mathrm{FF}^{1}$ & $19,77 \mathrm{a}$ & $16,08 \mathrm{~b}$ & $15,54 \mathrm{~b}$ & 18,31 \\
$\mathrm{El}^{2}$ & $19,56 \mathrm{a}$ & $18,27 \mathrm{a}$ & $17,09 \mathrm{a}$ & 13,51 \\
\hline Média & $19,57 \mathrm{a}$ & $16,16 \mathrm{~b}$ & $16,79 \mathrm{a}$ & 17,51 \\
\hline
\end{tabular}

Forragem fresca', Emurchecida inteira ${ }^{2}$, Emurchecida triturada ${ }^{3}$.

Médias seguidas de letras distintas, na coluna, diferem entre si pelo teste de Tukey $(P<0,05)$.

$\mathrm{Na}$ idade de 84 dias, a forragem emurchecida inteira (17,09 e.mg de $\mathrm{HCl} / 100 \mathrm{~g} \mathrm{MS})$ e a forragem emurchecida triturada $(16,79)$ apresentaram maior poder tampão $(P<0,05)$ do que a forragem fresca $(15,54)$, não havendo diferença significativa entre as duas primeiras $(P>0,05)$.

$O$ resultado encontrado para a forragem fresca aos 56 dias foi inferior ao valor de Andrade (1995) e ao de Henrique (1990), os quais registraram 27,38 e 27,25 e.mg de $\mathrm{HCl} / 100 \mathrm{~g}$ de $\mathrm{MS}$ para o capim-elefante, cultivar Guaçu, cortado aos 62 e 63 dias de desenvolvimento, respectivamente. 
Na idade de 70 dias, os resultados foram inferiores aos Lavezzo et al. (1990), 19,87 e 24,03 e.mg de $\mathrm{HCl} / 100 \mathrm{~g}$ de MS para o capim-elefante, cultivares Mineiro e Vruckwona, respectivamente, cortado aos 75 dias de desenvolvimento.

Os resultados encontrados para as forragens emurchecidas foram inferiores aos valores de Gutierrez \& Farias (1978), 21,05; 21,82; 21,64 e 20,92 e.mg de $\mathrm{HCl} / 100 \mathrm{~g}$ de $\mathrm{MS}$, respectivamente, quando cortaram o capimelefante, cultivar Taiwan A-148, aos 62 dias de desenvolvimento, submetendoo ao emurchecimento durante $0,2,4$ e 6 horas.

O desdobramento do efeito de idade, dentro de tipos de forragem, através de análise de regressão, mostrou que as variações dos valores de poder tampão das forragens fresca e emurchecida inteira podem ser representadas por curvas lineares $(P<0,05)$, conforme equações: $y: 27,6978$ $0,1510 x$, com $R^{2}=0,8435$ e $y=24,4900-0,0883 x$, com $R^{2}=0,9992$, respectivamente. Por outro lado, a variação dos valores de poder tampão da forragem emurchecida triturada pode ser representada por uma curva quadrática $(P<0,05)$, conforme a equação: $y=73,6900-1,5445 x+0,0103 x^{2}$, com $R^{2}=1,0000$. As variações dos valores de poder tampão são ilustradas na Figura 7 .

Pela ilustração da Figura 7, percebe-se que o poder tampão, de modo geral, diminuiu com a maturidade da planta para a forragem fresca e emurchecida. A elevação do poder tampão da forragem emurchecida triturada, na idade de 84 dias, deve estar relacionada à menor perda de umidade do material $(28,01 \%$ de MS), conforme Tabela 4 . Com exceção da forragem emurchecida triturada, os resultados observados estão de acordo com os de Faria (1971), quando determinou o poder tampão das forragens fresca e emurchecida do capim-elefante, cultivar Napier, aos 51,86 e 126 dias de desenvolvimento, encontrando, 55,26; 44,97 e 36,81 mg de ácido láctico por $\mathrm{g}$ de MS e 37,$44 ; 35,73$ e 32,58, respectivamente. 


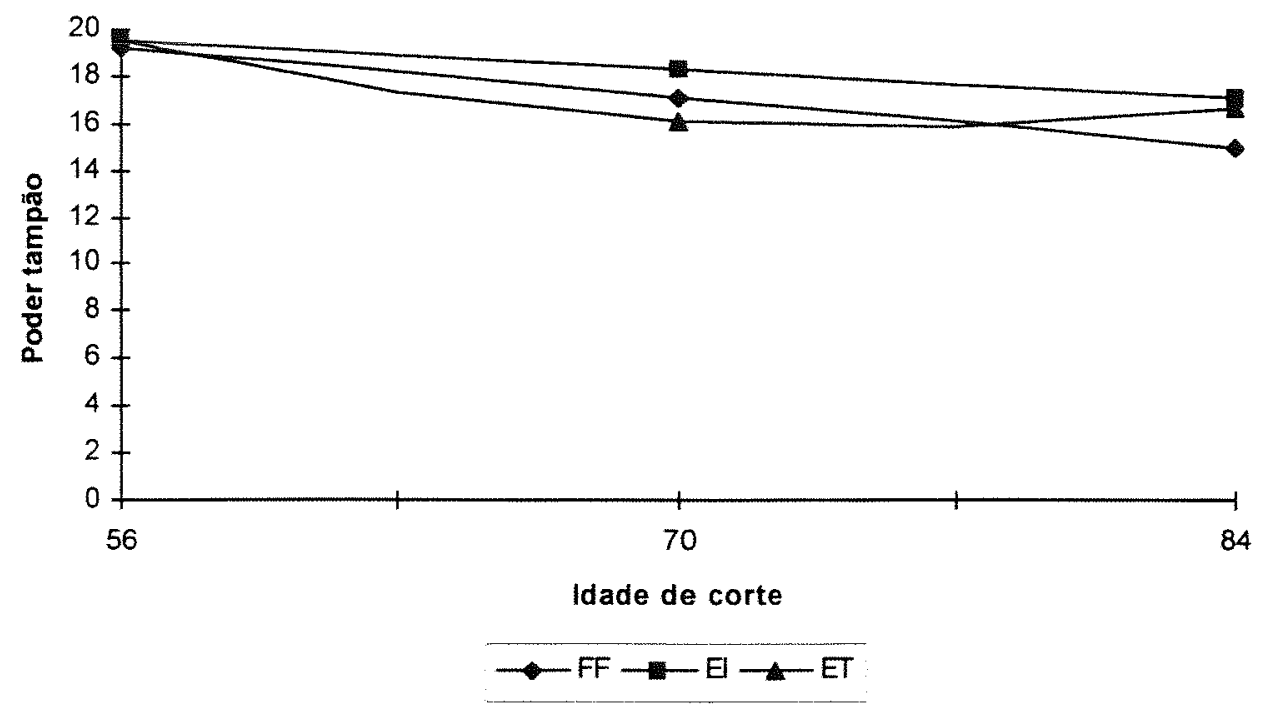

Figura 7. Variações dos valores de poder tampão das forragens fresca e emurchecidas (inteira e triturada) do capim-elefante, cultivar Guaçu, aos 56,70 e 84 dias de desenvolvimento.

Os resultados ilustrados para a forragem fresca são semelhantes aos de Gutierrez (1975) quando avaliou vários cultivares de capim-elefante aos 37 e 97 dias de desenvolvimento e verificou que o poder tampão decresceu com a maturidade da planta, registrando valores de 14 a 16 e 13 a 15 e.mg de $\mathrm{HCl} / 100 \mathrm{~g}$ de MS, respectivamente.

\subsection{Qualidade das silagens}

\subsubsection{Densidade}

As densidades das silagens são apresentadas na Tabela 9. 
Tabela 9. Densidade das silagens do capim-elefante $\left(\mathrm{em} \mathrm{kg} / \mathrm{m}^{3}\right)$, cultivar Guaçu, confeccionadas com as forragens fresca e emurchecidas (inteira e triturada), aos 56,70 e 84 dias de desenvolvimento.

\begin{tabular}{ccccc}
\hline & \multicolumn{4}{c}{ Idade de corte } \\
\cline { 2 - 5 } Tipo de forragem & 56 & 70 & 84 & Média \\
\hline FF $^{1}$ & 536 & 613 & 600 & $583 \mathrm{a}$ \\
El $^{2}$ & 564 & 532 & 529 & $542 \mathrm{ab}$ \\
ET $^{3}$ & 523 & 507 & 484 & $505 \quad b$ \\
\hline Média & 541 & 551 & 538 &
\end{tabular}

Forragem fresca', Emurchecida inteira ${ }^{2}$, Emurchecida triturada ${ }^{3}$.

Médias seguidas de letras distintas, na coluna, diferem entre si pelo teste de Tukey $(P<0,05)$.

$\mathrm{Na}$ análise de variância das densidades, foi observada diferença mínima significativa para tipo de forragem $(P<0,01)$, não havendo diferença significativa para idade $(P>0,05)$ e nem foi detectada interação entre idade e tipo de forragem $(P>0,05)$. $O$ coeficiente de variação encontrado foi de $7,13 \%$.

A densidade das silagens feitas com a forragem fresca $\left(583 \mathrm{~kg} / \mathrm{m}^{3}\right)$ foi semelhante $(P>0,05)^{`} \mathrm{a}$ da preparada com a forragem emurchecida inteira $\left(542 \mathrm{~kg} / \mathrm{m}^{3}\right)$, sendo superior $(P<0,05)$ a da silagem confeccionada com a forragem emurchecida triturada $\left(505 \mathrm{~kg} / \mathrm{m}^{3}\right)$. Por outro lado, a densidade das silagens feitas com a forragem emurchecida inteira foi semelhante 'a das silagens preparadas com a forragem emurchecida triturada $(P>0,05)$. 
Os resultados encontrados para as silagens feitas com a forragem fresca foram superiores ao de Lima et al. (1972), $467 \mathrm{~kg} / \mathrm{m}^{3}$, quando ensilaram o capim-elefante, cultivar Elefante de Pinda, fresco, quando a planta atingia $1,50 \mathrm{~m}$ de altura, utilizando-se como silos experimentais manilhas de $0,60 \mathrm{~m}$ de diâmetro por $1,20 \mathrm{~m}$ de altura. Considerando as silagens feitas com as forragens fresca e emurchecida inteira, os resultados registrados foram superiores também aos valores de Tosi et al. (1983a), 464, 406 e $359 \mathrm{~kg} / \mathrm{m}^{3}$, quando ensilaram o capim-elefante, cultivar Taiwan A-148, fresco, emurchecido durante 8 horas exposto ao sol e durante $12 \mathrm{~h}$ e 30 minutos, respectivamente, aos 55 dias de desenvolvimento, utilizando-se tambores metálicos de 200 litros como silos experimentais.

Pelos valores encontrados, pode-se dizer que a compactação da massa foi satisfatória, minimizando as perdas por respiração celular no interior do silo e a fermentação dos microorganismos aeróbios.

\subsubsection{Porcentagem de matéria seca}

As porcentagens de matéria seca das silagens são apresentadas na Tabela 10 .

$\mathrm{Na}$ análise de variância dos teores de matéria seca, foi observada diferença mínima significativa para idade e tipo de forragem $(P<0,01)$, havendo interação entre idade e tipo de forragem $(P<0,05)$. $O$ coeficiente de variação encontrado foi de $3,84 \%$.

$O$ desdobramento de tipos de forragem, dentro de idade de corte, mostrou que, na idade de 56 dias, o teor de $27,10 \%$ de matéria seca da silagem feita com a forragem emurchecida inteira foi superior $(P<0,05)$ aos das demais silagens, vindo a seguir a silagem feita com a forragem emurchecida triturada $(24,70 \%)$ que apresentou teor maior que o da silagem confeccionada com a forragem fresca $(19,16 \%)$. 
$\mathrm{Na}$ idade de 70 dias, não houve diferença significativa $(P>0,05)$ entre os teores de matéria seca das silagens confeccionadas com a forragem emurchecida inteira $(26,75 \%)$ e triturada $(27,23 \%)$, as quais apresentaram teores superiores $(P<0,05)$ ao da silagem feita com a planta fresca $(20,42 \%)$.

Tabela 10. Porcentagem de matéria seca das silagens do capim-elefante, cultivar Guaçu, confeccionadas com as forragens fresca e emurchecidas (inteira e triturada), aos 56,70 e 84 dias de desenvolvimento.

\begin{tabular}{ccccc}
\hline & \multicolumn{3}{c}{ Idade de corte } & \multirow{2}{*}{ Média } \\
\cline { 2 - 4 } Tipo de forragem & 56 & 70 & 84 & 20,58 \\
FF $^{1}$ & $19,16 \mathrm{c}$ & $20,42 \mathrm{~b}$ & $22,16 \mathrm{c}$ & 28,53 \\
$\mathrm{El}^{2}$ & $27,10 \mathrm{a}$ & $26,75 \mathrm{a}$ & $31,74 \mathrm{a}$ & 28,11 \\
\hline ET & & & & \\
\hline Média & $24,70 \mathrm{~b}$ & $27,23 \mathrm{a}$ & $29,39 \mathrm{~b}$ & 27,11 \\
\hline
\end{tabular}

Forragem fresca', Emurchecida inteira ${ }^{2}$, Emurchecida triturada $^{3}$.

Médias seguidas de letras distintas, na coluna, diferem entre si pelo teste de Tukey $(P<0,05)$

$\mathrm{Na}$ idade de 84 dias, o teor de matéria seca $(31,74 \%)$ da silagem feita com a forragem emurchecida inteira foi superior $(P<0,05)$ aos teores das demais silagens, vindo, em seguida, a silagem com a forragem emurchecida triturada $(29,39 \%)$ com teor maior $(P<0,05)$ que o da silagem com a forragem fresca $(22,16 \%)$. 
Comparando-se os teores de matéria seca das silagens com os das respectivas forragens, verifica-se que houve redução de matéria seca, a qual não pode ser explicada considerando a boa fermentação ocorrida no interior dos silos.

Os resultados encontrados foram próximos aos valores de Machado Filho et al. (1986), $19,4 \%$ e $27,6 \%$, para silagens feitas com a forragem fresca e emurchecida, respectivamente, do capim-elefante, cultivar Cameron, aos 120 dias de desenvolvimento. Foram próximos também dos valores de Alberto et al. (1993), 22,23\% e 29,88\%, para as silagens feitas com - capim-elefante, cultivar Cameron, fresco e emurchecido, respectivamente, aos 75 dias de desenvolvimento.

O desdobramento do efeito de idade, dentro de tipos de forragem, através de análise de regressão, mostrou que as variações dos teores de matéria seca das silagens confeccionadas com as forragens fresca e emurchecida triturada podem ser representadas por curvas lineares $(P<0,05)$, conforme as equações: $y=13,0811+0,1071 x$, com $R^{2}=0,9918$ e $y=15,3756$ $+0,1676 x$, com $R^{2}=0,9979$, respectivamente. Por outro lado, a variação dos teores de matéria seca das silagens feitas com a forragem emurchecida inteira pode ser representada por uma curva quadrática $(P<0,05)$, conforme equação: $y=81,8200-1,7390 x+0,0136 x^{2}$, com $R^{2}=1,0000$. As variações dos teores de matéria seca das silagens sāo ilustradas na Figura 8.

Pela ilustração da Figura 8, como era esperado, os teores de matéria seca das silagens tiveram o mesmo comportamento das forragens, ou seja, aumentaram com a idade do capim, estando de acordo com os dados de Faria (1971) quando ensilou o capim-elefante, cultivar Napier, fresco e emurchecido nas idades de 51, 86 e 121 dias, registrando 14,83\%, 18,95\% e $23,62 \%$ para a silagem feita com a forragem fresca e $16,37 \%, 22,12 \%$ e $28,35 \%$ para a silagem com a forragem emurchecida. 


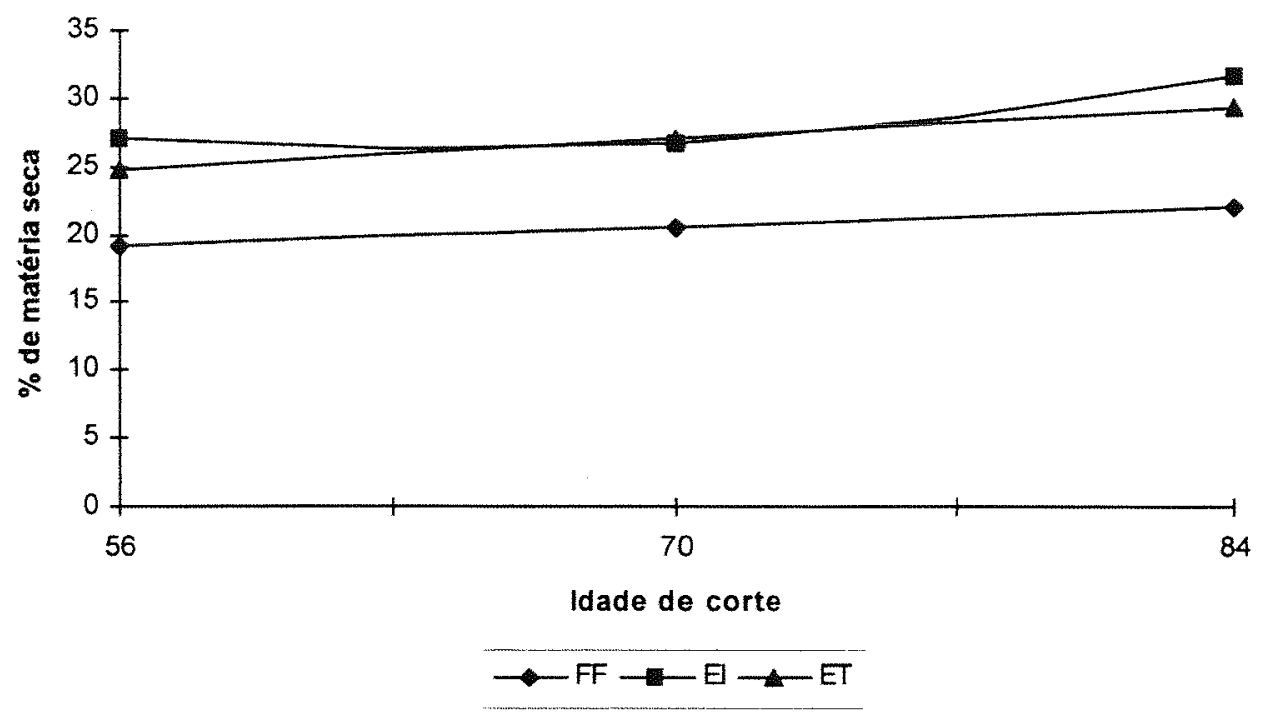

Figura 8. Variações das porcentagens de matéria seca das silagens do capimelefante, cultivar Guaçu, confeccionadas com as forragens fresca e emurchecidas (inteira e triturada), aos 56,70 e 84 dias de desenvolvimento.

\subsubsection{Valores de $\mathrm{pH}$}

Os valores de $\mathrm{pH}$ das silagens são apresentados na Tabela 11.

$\mathrm{Na}$ análise de variância dos valores de $\mathrm{pH}$, foi observada diferença minima significativa para idade e tipo de forragem $(P<0,01)$, não havendo interação entre idade e tipo de forragem $(P>0,05)$. $O$ coeficiente de variação encontrado foi de $1,78 \%$.

$\mathrm{O} \mathrm{pH}$ das silagens feitas com a forragem emurchecida inteira $(3,54)$ foi superior $(P<0,05)$ ao das silagens preparadas com a forragem fresca $(3,31)$ e emurchecida triturada $(3,36)$, não havendo diferença significativa entre os valores das duas últimas $(P>0,05)$. 
Tabela 11. Valores de pH das silagens do capim-elefante, cultivar Guaçu, confeccionadas com as forragens fresca e emurchecidas (inteira e triturada), aos 56,70 e 84 dias de desenvolvimento.

\begin{tabular}{ccccc}
\hline & \multicolumn{3}{c}{ Idade de corte } & \multirow{2}{*}{ Média } \\
\cline { 2 - 4 } Tipo de forragem & 56 & 70 & 84 & $3,31 \mathrm{~b}$ \\
$\mathrm{FF}^{1}$ & 3,44 & 3,22 & 3,26 & $3,54 \mathrm{a}$ \\
$\mathrm{El}^{2}$ & 3,61 & 3,44 & 3,58 & $3,36 \mathrm{~b}$ \\
\hline $\mathrm{ET}^{3}$ & 3,39 & 3,34 & 3,35 & \\
\hline Média & 3,48 & 3,33 & 3,40 & \\
\hline
\end{tabular}

Forragem fresca', Emurchecida inteira ${ }^{2}$, Emurchecida triturada ${ }^{3}$.

Médias seguidas de letras distintas, na coluna, diferem entre si pelo teste de Tukey $(P<0,05)$.

Os valores de $\mathrm{pH}$ encontrados estão de acordo com o limite indicado para uma silagem com bom padrão de fermentação, segundo Toth et al. (1956); Weringa (1966) e Silveira (1975) o qual não deve ultrapassar 4,2.

Os resultados de $\mathrm{pH}$ encontrados foram inferiores ao valor de Tosi et al. (1989), 3,88, quandolensilaram o capim-elefante, cultivar Taiwan A-148, fresco aos 63 dias de desenvolvimento; aos de Lopes \& Monks (1983), 3,8 e 4,0, quando ensilaram o capim-elefante, cultivar Cameron, fresco e emurchecido, respectivamente, aos 60 dias de desenvolvimento e ao valor de Peres (1997), 3,84, quando trabalhou com o capim-elefante, cultivar Roxo, aos 72 dias de desenvolvimento.

O estudo do efeito de idade, através de análise de regressão, mostrou que a variação dos valores de $\mathrm{pH}$ das silagens confeccionadas com as forragens fresca e emurchecidas pode ser representada por uma curva 
quadrática $(P<0,05)$, conforme a equação: $y=6,2644-0,0808 x+0,0006 x^{2}$, com $R^{2}=1,0000$. A variação dos valores de $\mathrm{pH}$ é ilustrada na Figura 9 .

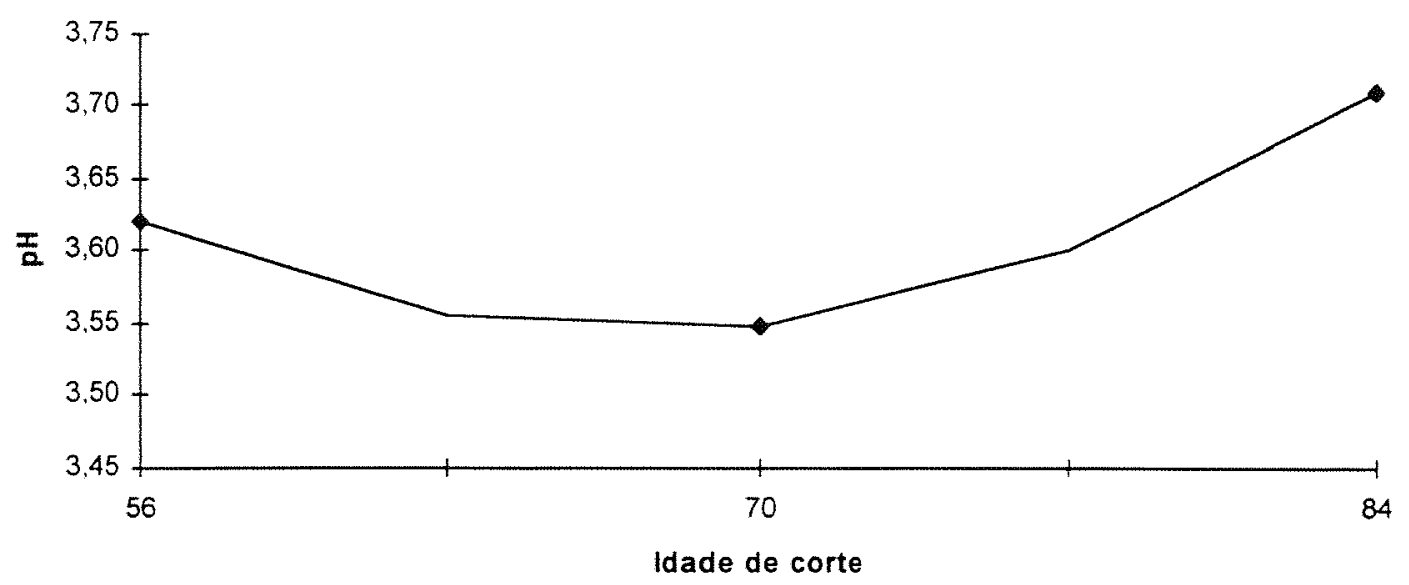

Figura 9. Variação dos valores de pH das silagens do capim-elefante, cultivar Guaçu, confeccionadas com as forragens fresca e emurchecidas (inteira e triturada), aos 56,70 e 84 dias de desenvolvimento.

Pela ilustração da Figura 9, os valores de pH estão de acordo com o comportamento dos resultados observados por Faria (1971), quando ensilou o capim-elefante, cultivar Napier, nas idades de 51,86 e 121 dias, submetendo-o ou não ao emurchecimento, encontrando-se 4,40; 4,03 e 4,63 para a forragem fresca e 4,66; 4,47 e 4,63 para a forragem emurchecida. Por outro lado, os resultados de Farias (1973), apresentaram comportamento diferente quando ensilou o capim-elefante fresco e emurchecido em diferentes estádios de maturidade, $15,7 \%, 23,0 \%$ e $29,7 \%$ de matéria seca, observandose valores de $\mathrm{pH}$ de 4,$1 ; 4,7$ e 3,9 para a silagem feita com a forragem fresca e 3,$8 ; 4,0$ e 3,9 para a silagem com a forragem emurchecida. Esta redução e elevação dos valores de $\mathrm{pH}$ devem estar associadas ao aumento e diminuição 
dos teores de carboidratos solúveis com o avanço da idade da planta, conforme Andrade \& Gomide (1971), havendo maior e menor fermentação láctica com a maturidade da planta, implicando em redução e elevação dos valores de $\mathrm{pH}$ das silagens.

\subsubsection{Porcentagem de ácido láctico}

As porcentagens de ácido láctico das silagens são apresentadas na Tabela 12.

Tabela 12. Porcentagem de ácido láctico das silagens do capim-elefante, cultivar Guaçu, confeccionadas com as forragens fresca e emurchecidas (inteira e triturada), aos 56,70 e 84 dias de desenvolvimento.

Idade de corte

Tipo de forragem

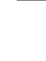

56

56

70

84

Média

$\begin{array}{lllll}\mathrm{FF}^{1} & 9,79 & 10,55 & 9,11 & 9,81 \mathrm{a} \\ \mathrm{El}^{2} & 7,70 & 7,40 & 5,29 & 6,80 \mathrm{C}\end{array}$

\begin{tabular}{ccccc}
$\mathrm{ET}^{3}$ & 9,20 & 8,48 & 6,93 & $8,20 \mathrm{~b}$ \\
\hline Média & 8,90 & 8,81 & 7,11
\end{tabular}

Forragem fresca', Emurchecida inteira ${ }^{2}$, Emurchecida triturada ${ }^{3}$.

Médias seguidas de letras distintas, na coluna, diferem entre si pelo teste de Tukey $(P<0,05)$.

$\mathrm{Na}$ análise de variância dos teores de ácido láctico, foi observada diferença mínima significativa para idade e tipo de forragem 
$(P<0,01)$, não havendo interação entre idade e tipo de forragem $(P>0,05) .0$ coeficiente de variação encontrado foi de $8,01 \%$.

A porcentagem de ácido láctico das silagens feitas com a forragem fresca $(9,81)$ foi superior $(P<0,05)$ às porcentagens das silagens preparadas com as forragens emurchecidas (inteira e triturada), 6,80 e 8,20 , respectivamente. Por outro lado, o teor de ácido láctico dassilagens feitascom a forragem emurchecida triturada foi superior $(P<0,05)$ ao dassilagenspreparadas com a forragem emurchecida inteira.

$\mathrm{Na}$ silagem feita com o capim emurchecido inteiro aos 70 dias de desenvolvimento, a forragem apresentava o menor nivel de carboidratos solúveis $(6,60 \%$ ) (Tabela 7 ). Embora baixo, foi suficiente para abaixar o $\mathrm{pH} d a$ silagem a 3,44 (Tabela 11). A forragem utilizada na confecção desta silagem apresentava teor de matéria seca de $30,25 \%$ (Tabela 4). Estes resultados estão de acordo com a afirmação de McCulloug (1977), quando ressaltou que a fermentação ideal no silo é esperada quando a forragem a ser ensilada possua de 28 a $34 \%$ de matéria seca, sendo que, nestas condições, mesmo teores de carboidratos solúveis de 6 a $8 \%$ na matéria seca seriam suficientes para desencadear fermentações lácticas, desde que o poder tampão não seja elevado.

Os valores de ácido láctico encontrados, exceto para a silagem feita com a forragem emurchecida inteira do capim aos 84 dias de desenvolvimento, foram superiores aos observados por Lopes \& Monks (1983), 5,36\% e 5,50\%, quando ensilaram o capim-elefante, cultivar Cameron, fresco e emurchecido, respectivamente, aos 60 dias de desenvolvimento. Por outro lado, foram inferiores aos resultados encontrados por Tosi et al. (1989), $13,93 \%, 17,73 \%$ e $11,01 \%$, para as silagens de capim-elefante, cultivar Taiwan A-148, quando utilizaram as forragens fresca, emurchecida durante 8 horas e emurchecida durante 12 horas e 30 minutos, respectivamente. 
O estudo do efeito de idade, através de análise de regressão, mostrou que a variação dos teores de ácido láctico das silagens confeccionadas com as forragens fresca e emurchecidas pode ser representada por uma curva quadrática $(P<0,05)$, conforme a equação: $y=-6,9511+0,5140 x-0,0041 x^{2}$, com $R^{2}=1,0000$. A variação dos teores de ácido láctico é ilustrada na Figura 10.

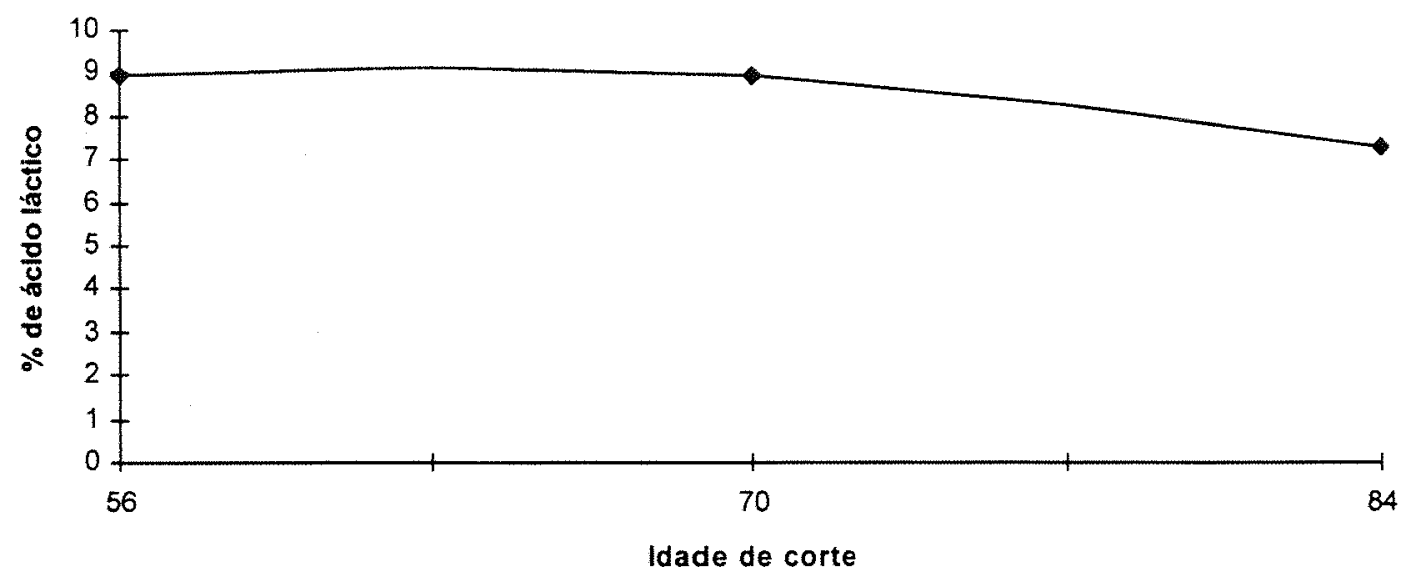

Figura 10. Variação das porcentagens de ácido láctico das silagens do capimelefante, cultivar Guaçu, confeccionadas com as forragens fresca e emurchecidas (inteira e triturada), aos 56,70 e 84 dias de desenvolvimento.

Pela ilustração da Figura 10, percebe-se que, de uma maneira geral, os teores de ácido láctico das silagens diminuíram com a idade do capim. No caso da silagem feita com a forragem fresca, o teor de ácido láctico aumentou e diminuiu com o avanço da idade da planta. Este comportamento deve estar associado ao aumento e diminuição dos teores de carboidratos 
solúveis com a maturidade da planta, segundo Andrade \& Gomide (1971), implicando em elevação e redução da fermentação láctica.

\subsubsection{Porcentagem de ácido acético}

As porcentagens de ácido acético das silagens são apresentadas na Tabela 13.

Tabela 13. Porcentagem de ácido acético das silagens do capim-elefante, cultivar Guaçu, confeccionadas com as forragens fresca e emurchecidas (inteira e triturada), aos 56.70 e 84 dias de desenvolvimento.

Idade de corte

Tipo de forragem

56

$56 \quad 70$

84

Média

$\begin{array}{lllll}\mathrm{FF}^{1} & 2,44 \mathrm{a} & 1,75 \mathrm{a} & 2,43 \mathrm{a} & 2,21 \\ \mathrm{El}^{2} & 2,01 \mathrm{~b} & 1,53 \mathrm{a} & 1,68 \mathrm{~b} & 1,74\end{array}$

$E T^{3}$

$1,00 \mathrm{c}$

$1,03 \mathrm{~b}$

$1,18 \mathrm{c}$

1,07

Média $\quad 1,82 \quad 1,44 \quad 1,76$

Forragem fresca', Emurchecida inteira ${ }^{2}$, Emurchecida triturada ${ }^{3}$.

Médias seguidas de letras distintas, na coluna, diferem entre si pelo teste de Tukey $(P<0,05)$.

$\mathrm{Na}$ análise de variância dos teores de ácido acético, foi observada diferença mínima significativa para idade e tipo de forragem $(P<0,01)$, havendo interação entre idade e tipo de forragem $(P<0,01)$. $O$ coeficiente de variação encontrado foi de $8,66 \%$. 
O desdobramento de tipos de forragem, dentro de idade de corte, mostrou que, na idade de 56 dias, o teor de ácido acético $(2,44 \%)$ da silagem feita com a forragem fresca foi superior $(P<0,05)$ ao da silagem feita com a forragem emurchecida inteira $(2,01 \%)$, sendo este último superior $(P<0,05)$ ao da silagem feita com a forragem emurchecida triturada $(1,00 \%)$.

$\mathrm{Na}$ idade de 70 dias, os teores de ácido acético das silagens feitas com as forragens fresca $(1,75 \%)$ e emurchecida inteira $(1,53 \%)$ foram superiores $(P<0,05)$ ao da silagem feita com a forragem emurchecida triturada $(1,03 \%)$, não havendo diferença significativa entre os dois primeiros $(P>0,05)$.

$\mathrm{Na}$ idade de 84 dias, o teor de ácido acético $(2,43 \%)$ da silagem feita com a forragem fresca foi superior $(P<0,05)$ ao da silagem com a forragem emurchecida inteira $(1,68 \%)$, sendo este último superior $(P<0,05)$ ao da silagem feita com a forragem emurchecida triturada $(1,18 \%)$.

Os valores de ácido acético encontrados para silagens feitas com forragem fresca foram inferiores aos observados por Silveira et al. (1979), $(5,93 ; 5,63 ; 3,50$ e 2,72), quando ensilaram o capim-elefante (Napier, Taiwan A-144, Mineiro e Vruckwona), respectivamente. No caso das silagens feitas com a forragem emurchecida inteira, os resultados foram inferiores aos valores encontrados por estes mesmos autores quando submeteram estes cultivares ao emurchecimento, com exceção do cultivar Mineiro, cuja silagem apresentou menor porcentagem de ácido acético $(1,26 \%)$. Por outro lado, foram superiores aos valores encontrados por Lavezzo et al. (1983), 0,36\% e 1,09\%, para as silagens de capim-elefante emurchecido, cultivares Mineiro e Vruckwona, respectivamente. No caso das silagens feitas com a forragem emurchecida triturada, os resultados foram superiores aos de Vilela \& Wilkinson (1987), $1,2 \% ; 0,8 \% ; 0,8 \%$ e $0,3 \%$, quando ensilaram o capim-elefante emurchecido triturado $(0,6,30$ e 54 horas de exposição ao sol). 
O desdobramento do efeito de idade, dentro de tipos de forragem, através de análise de regressão, mostrou que as variações dos teores de ácido acético das silagens confeccionadas com as forragens fresca $e$ emurchecida inteira podem ser representadas por curvas quadráticas $(P<0,05)$, conforme as equações: $y=18,9167-0,4899 x+0,0035 x^{2}$, com $R^{2}=1,0000$ e $y=10,1500-0,2344 x+0,0016 x^{2}$, com $R^{2}=1,000$, respectivamente. Por outro lado, a variação do ácido acético das silagens feitas com a forragem emurchecida triturada não pode ser explicada por análise de regressão (linear e quadrática). As variações dos teores de ácido acético são ilustradas na Figura 11.

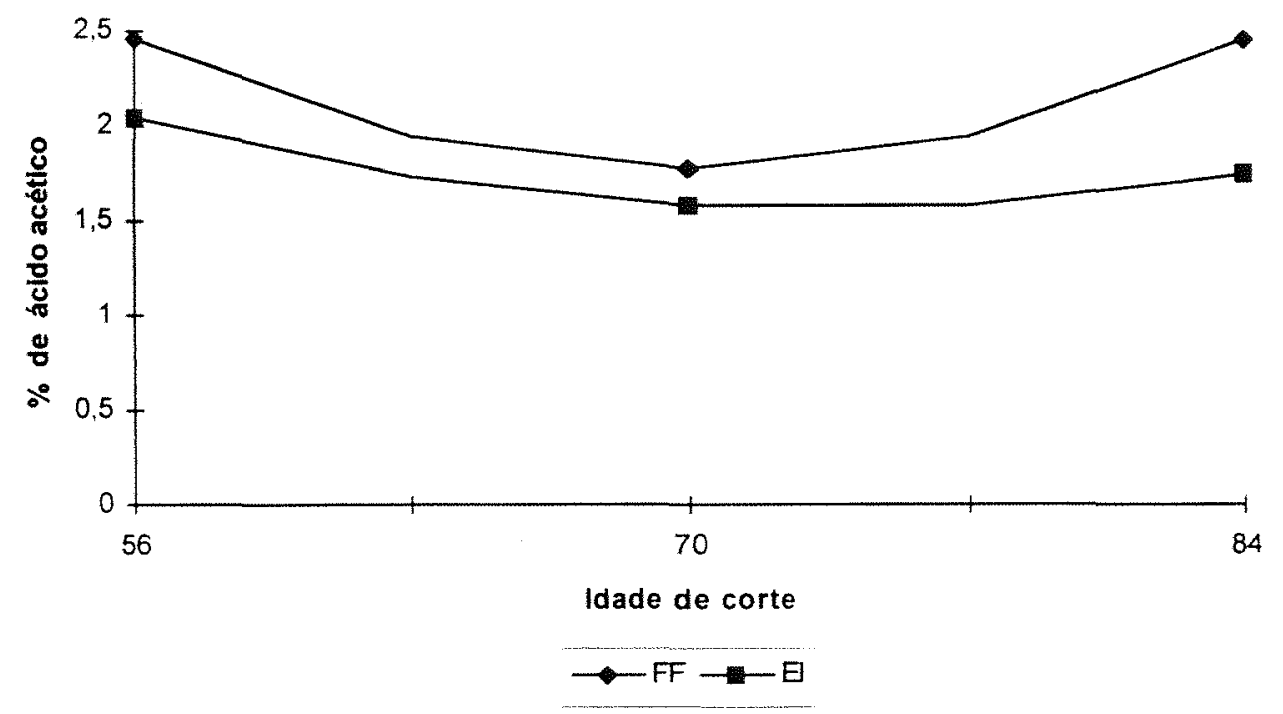

Figura 11. Variações das porcentagens de ácido acético das silagens do capim-elefante, cultivar Guaçu, confeccionadas com as forragens fresca e emurchecida inteira , aos 56,70 e 84 dias de desenvolvimento.

$\mathrm{Na}$ ilustração da Figura 11, nota-se que os teores de ácido acético das silagens diminuíram e aumentaram com a maturidade da planta. 
Este comportamento está, de certa forma, de acordo com os resultados encontrados por Faria (1971), quando ensilou o capim-elefante, cultivar Napier, fresco e emurchecido, aos 51, 86 e 121 dias de desenvolvimento, encontrandose, respectivamente, $5,05 \%, 2,35 \%$ e $2,75 \%$ de ácido acético para a silagem feita com a forragem fresca e $6,61 \%, 2,26 \%$ e $1,91 \%$ para a silagem com a forragem emurchecida.

\subsubsection{Porcentagem de ácido propiônico}

As porcentagens de ácido propiônico das silagens são apresentadas na Tabela 14.

Tabela 14. Porcentagem de ácido propiônico das silagens do capim-elefante, cultivar Guaçu, confeccionadas com as forragens fresca e emurchecidas (inteira e triturada), aos 56,70 e 84 dias de desenvolvimento.

Idade de corte

\begin{tabular}{ccccc} 
Tipo de forragem & 56 & 70 & 84 & Média \\
\hline $\mathrm{FF}^{1}$ & 0,008 & 0,018 & 0,012 & $0,013 \mathrm{~b}$ \\
$\mathrm{El}^{2}$ & 0,054 & 0,058 & 0,052 & $0,055 \mathrm{a}$ \\
$\mathrm{ET}^{3}$ & 0,081 & 0,067 & 0,062 & $0,070 \mathrm{a}$ \\
\hline Média & 0,048 & 0,048 & 0,042 &
\end{tabular}

Forragem fresca', Emurchecida inteira ${ }^{2}$, Emurchecida triturada ${ }^{2}$.

Médias seguidas de letras distintas, na coluna, diferem entre si pelo teste de Tukey $(P<0,05)$. 
$\mathrm{Na}$ análise de variância dos teores de ácido propiônico, foi observada diferença mínima significativa apenas para tipo de forragem $(P<0,01)$, não havendo diferença $(P>0,05)$ para idade e nem foi observada interação entre idade e tipo de forragem $(P>0,05)$. $O$ coeficiente de variação encontrado foi de $28,36 \%$.

As porcentagens de ácido propiônico das silagens feitas com as forragens emurchecidas (inteira e triturada), $0,055 \%$ e $0,07 \%$, respectivamente, foram semelhantes $(P>0,05)$, sendo estas superiores $(P<0,05)$ à da silagem preparada com a forragem fresca $(0,013 \%)$.

$\mathrm{Na}$ análise de regressão para estudar o efeito de idade, também não foi encontrada diferença significativa $(P>0,05)$, mostrando que a variação nos teores de ácido propiônico não pode ser explicada por curva linear ou quadrática.

Os valores encontrados foram inferiores ao de Andrade (1995), 0,08\%, exceto para a silagem feita com a forragem emurchecida triturada $(0,081 \%)$, qu ando ensilou o capim-elefante fresco aos 62 dias de desenvolvimento. Foram inferiores também aos resultados de Tosi et al. (1989), quando ensilaram o capim-elefante, cultivar Taiwan A-148, encontrando-se $0,1259 \% ; 0,1548 \%$ e $0,0918 \%$ para as silagens feitas com as forragens fresca, emurchecida durante 8 horas exposta ao sol e emurchecida durante 12 horas e 30 minutos. No caso das silagens confeccionadas com as forragens emurchecidas, os resultados foram superiores ao de Alberto et al. (1993), 0,01\%, quando ensilaram o capim-elefante, cultivar Cameron, aos 75 dias de desenvolvimento, submetido ao emurchecimento. 


\subsubsection{Porcentagem de ácido butírico}

As porcentagens de ácido butírico das silagens são apresentadas na Tabela 15.

Tabela 15. Porcentagem de ácido butírico das silagens do capim-elefante, cultivar Guaçu, confeccionadas com as forragens fresca $e$ emurchecidas (inteira e triturada), aos 56,70 e 84 dias de desenvolvimento.

\begin{tabular}{ccccc}
\hline & \multicolumn{3}{c}{ Idade de corte } & \multirow{2}{*}{ Média } \\
\cline { 2 - 4 } Tipo de forragem & 56 & 70 & 84 & 0,001 \\
$\mathrm{FF}^{1}$ & 0,001 & 0,003 & 0,000 & 0,001 \\
$\mathrm{El}^{2}$ & 0,000 & 0,001 & 0,002 & 0.007 \\
\hline Média & 0,016 & 0,000 & 0,004 & 0,002 \\
\hline
\end{tabular}

Forragem fresca', Emurchecida inteira ${ }^{2}$, Emurchecida triturada ${ }^{3}$.

Não foi realizada análise de variância dos teores de ácido butírico, considerando que os valores foram iguais a zero em mais de $60 \%$ dos dados.

De acordo com a porcentagem de ácido butírico na matéria seca, a silagem pode ser classificada, segundo Toth et al. (1956). em muito boa $(0,0$ a $0,10 \%)$; boa $(0,11$ a $0,20 \%)$; média $(0,21$ a $0,30 \%)$; ruim $(0,31$ a $0,40 \%$ ) e péssima (acima de $0,41 \%$ ). Segundo este critério de classificação, todas as silagens podem ser consideradas muito boas. 
Os valores encontrados foram inferiores aos $0,20 \%$ de Andrade (1995), quando ensilou o capim-elefante fresco aos 62 dias de desenvolvimento e os $0,053 \%$ de Peres (1997), quando trabalhou com o capimelefante, cultivar Roxo, aos 72 dias de desenvolvimento. Foram inferiores também aos resultados de Vilela \& Wilkinson (1987), quando ensilaram o capim-elefante emurchecido triturado, aos 60 dias de desenvolvimento, durante $0,6,30$ e 54 horas de exposição ao sol e aos de Machado Filho et al. (1986), quando ensilaram o capim-elefante, cultivar Cameron, fresco e emurchecido, aos 120 dias de desenvolvimento.

\subsubsection{Porcentagem de nitrogênio amoniacal em relação ao nitrogênio total}

As porcentagens de nitrogênio amoniacal das silagens são apresentadas na Tabela 16.

$\mathrm{Na}$ análise de variância dos teores de nitrogênio amoniacal, foi observada diferença mínima significativa para tipo de forragem $(P<0,01)$, não havendo diferença significativa para idade $(P>0,05)$. Por outro lado, verificouse interação entre idade e tipo de forragem $(P<0,01)$. $O$ coeficiente de variação encontrado foi de $10,16 \%$.

$O$ desdobramento de tipos de forragem, dentro de idade de corte, mostrou que, na idade de 56 dias, os teores de nitrogênio amoniacal das silagens feitas com as forragens fresca $(11,16 \%)$ e emurchecida inteira $(10,65 \%)$ foram superiores $(P<0,05)$ ao da silagem feita com a forragem emurchecida triturada (5,19\%), não havendo diferença significativa entre os teores das duas primeiras $(P>0,05)$.

$\mathrm{Na}$ idade de 70 dias, verificou-se que os teores de nitrogênio amoniacal tiveram o mesmo comportamento dos resultados observados para a idade de 56 dias. 
Tabela 16. Porcentagem de nitrogênio amoniacal, em relação ao nitrogênio total, das silagens do capim-elefante, cultivar Guaçu, confeccionadas com as forragens fresca e emurchecidas (inteira e triturada), aos 56,70 e 84 dias de desenvolvimento.

\begin{tabular}{ccccc}
\hline & \multicolumn{4}{c}{ Idade de corte } \\
\cline { 2 - 5 } Tipo de forragem & 56 & 70 & 84 & Média \\
\hline$F^{1}$ & $11,16 a$ & $10,16 a$ & $8,47 b$ & 9,73 \\
$E^{2}$ & $10,65 a$ & $9,99 a$ & $10,75 a$ & 10,46 \\
$E^{2}$ & $5,19 b$ & $7,44 b$ & $8,53 b$ & 7,05 \\
\hline Média & 9,00 & 9,20 & 9,25 &
\end{tabular}

Forragem fresca', Emurchecida inteira ${ }^{2}$, Emurchecida triturada $^{3}$.

Médias seguidas de letras distintas, na coluna, diferem entre si pelo teste de Tukey $(P<0,05)$.

$\mathrm{Na}$ idade de 84 dias, o teor de nitrogênio amoniacal da silagem feita com a forragem emurchecida inteira $(10,75 \%)$ foi superior $(P<0,05)$ aos das silagens feitas com as forragens fresca $(8,47 \%)$ e emurchecida triturada $(8,53 \%)$, não havendo diferença significativa entre duas últimas $(P>0,05)$.

De acordo com a porcentagem de nitrogênio amoniacal, na matéria seca em relação ao nitrogênio total, a silagem pode ser classificada, segundo Benacchio (1965), em muito boa $\left(0,0\right.$ a 10,0\% de $\left.N_{-} \mathrm{NH}_{3}\right)$; boa $(10,0$ a $15,0 \%$ ); aceitável $(15,0$ a $20,0 \%$ ) e ruim (acima de $20,0 \%$ ). Segundo este critério de classificação, as silagens confeccionadas com a forragem emurchecida triturada pode ser considerada muito boa e com as forragens fresca e emurchecida inteira como boa. A baixa porcentagem de nitrogênio amoniacal encontrada em todas as silagens reflete a boa fermentação ocorrida. 
Pode-se afirmar que, praticamente, não houve proteólise, considerando os baixos valores registrados para o ácido butírico, conforme Tabela 15. As bactérias do gênero Clostridium responsáveis pela degradação de proteína na ensilagem são inibidas pela carência de umidade, segundo Wieringa (1958).

Os valores encontrados para as silagens feitas com as forragens fresca e emurchecida inteira foram próximos aos resultados de Lopes \& Monks (1983), 9,23\% e 9,33\%, observados para silagens de capim-elefante, cultivar Cameron, fresco e emurchecido, respectivamente, aos 60 dias de desenvolvimento. Por outro lado, foram inferiores aos $12,7 \%$ de Peres (1997) quando trabalhou com o capim-elefante, cultivar Roxo, aos 72 dias de desenvolvimento.

O desdobramento do efeito de idade, dentro de tipos de forragem, através de análise de regressão, mostrou que as variações dos teores de nitrogênio amoniacal das silagens confeccionadas com as forragens fresca e emurchecida triturada podem ser representadas por curvas lineares $(P<0,05)$, conforme as equações: $y=16,6644-0,0962 x$, com $R^{2}=0,9788$ e $y=-1,2956+0,1193 x$, com $R^{2}=0,9609$, respectivamente. Por outro lado, a variação do nitrogênio amoniacal das silagens feitas com a forragem emurchecida inteira não pode ser explicada por análise de regressão (linear e quadrática). As variações dos teores de nitrogênio amoniacal são ilustradas na Figura 12.

$\mathrm{Na}$ ilustração da Figura 12, nota-se que a porcentagem de nitrogênio amoniacal das silagens confeccionadas com a forragem fresca diminuiu com a maturidade da planta, ocorrendo o inverso com as silagens feitas com a forragem emurchecida triturada. A redução verificada nas silagens preparadas com a forragem fresca deve estar associada ao aumento do teor de matéria seca da forragem com a maturidade da planta, impedindo a ação dos microorganismos responsáveis pela degradação da proteína. Embora tenha havido elevação na porcentagem de nitrogênio amoniacal nas silagens 
confeccionadas com a forragem emurchecida triturada, os niveis alcançados foram baixos, de acordo com a classificação de Benachio (1965).

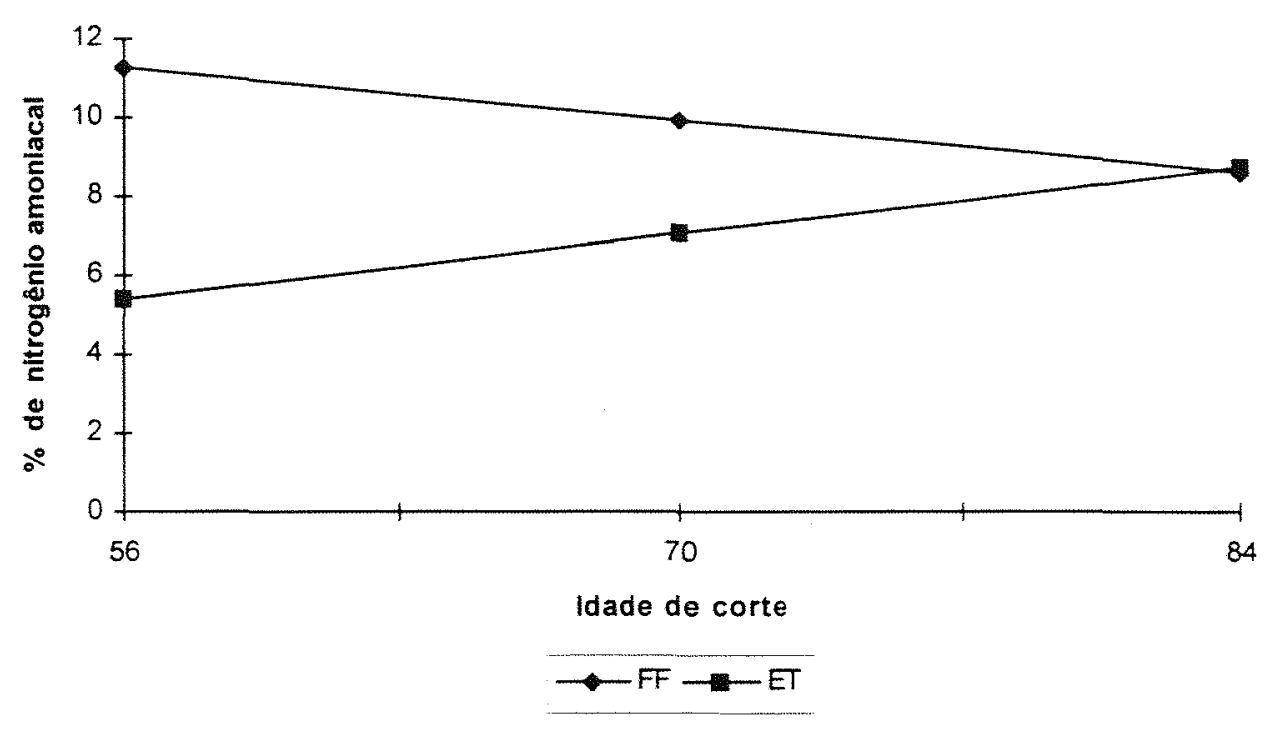

Figura 12. Variações das porcentagens de nitrogênio amoniacal das silagens do capim-elefante, cultivar Guaçu, confeccionadas com as forragens fresca e emurchecida triturada, aos 56,70 e 84 dias de desenvolvimento.

\subsection{Consumo e digestibilidade das silagens}

\subsubsection{Ingestão de matéria seca das silagens}

Os valores de ingestão de matéria seca das silagens são apresentados na Tabela 17.

$\mathrm{Na}$ análise de variância do consumo de matéria seca das silagens, foi observada diferença mínima significativa $(P<0,05)$ para tipo de forragem, não havendo efeito de idade e nem foi observada interação entre 
idade e tipo de forragem $(P>0,05)$. $O$ coeficiente de variação encontrado foi de $21,60 \%$.

Tabela 17. Valores de ingestão de matéria seca (em g MS/ $\mathrm{kg}^{0,75}$ e em porcentagem do peso vivo) das silagens do capim-elefante, cultivar Guaçu, confeccionadas com as forragens fresca e emurchecidas (inteira e triturada), aos 56,70 e 84 dias de desenvolvimento.

Idade de corte

\begin{tabular}{llll}
\cline { 2 - 3 } Tipo de forragem & 56 & 70 & 84
\end{tabular}

\begin{tabular}{|c|c|c|c|c|}
\hline $\mathrm{FF}^{1}$ & $34,10(1,59)$ & $26,14 \quad(1,21)$ & $24,45(1,15)$ & $28,23(1,32) b$ \\
\hline$E I^{2}$ & $44,10 \quad(2,01)$ & $33,10 \quad(1,53)$ & $34,45(1,56)$ & $37,22(1,70) a$ \\
\hline$E T^{3}$ & $36,17 \quad(1,67)$ & $37,33(1,70)$ & $32,02(1,51)$ & $35,17(1,63) a b$ \\
\hline Média & 38,12 & 32,19 & 30,31 & \\
\hline
\end{tabular}

Forragem fresca', Emurchecida inteira ${ }^{2}$, Emurchecida triturada $^{3}$.

Médias seguidas de letras distintas, na coluna, diferem entre si pelo teste de Tukey $(P<0,05)$.

O consumo médio de matéria seca das silagens feitas com a forragem emurchecida inteira $\left(37,22 \mathrm{gMSkg}^{0.75}\right)$ foi semelhante $(P>0,05)$ ao das silagens preparadas com a forragem emurchecida triturada $\left(35,17 \mathrm{gMS} / \mathrm{kg}^{0,75}\right)$, sendo superior $(P<0,05)$ ao das silagens confeccionadas com a forragem fresca $\left(28,23 \mathrm{gMS} / \mathrm{kg}^{0.75}\right)$. Por outro lado, os consumos das silagens feitas com a forragem fresca e emurchecida triturada foram semelhantes $(P>0,05)$. O menor consumo das silagens preparadas com a 
forragem fresca deve estar associado à maior acidez destas silagens, conforme Tabela 11.

Os valores encontrados para o consumo das silagens feitas com a forragem fresca foram inferiores ao resultado de Andrade (1995), $36,56 \mathrm{gMS} / \mathrm{kg}^{0.75}$, quando ensilou o capim-elefante, cultivar Guaçu, aos 62 dias de desenvolvimento e ao de Peres (1997), 35,8 gMS/UTM, quando trabalhou com o capim-elefante, cultivar Roxo, aos 72 dias de desenvolvimento. $\mathrm{Na}$ silagem feita com a forragem fresca aos 56 dias, o resultado encontrado foi superior ao de Evangelista et al. (1987), 29,7 g MS/UTM, quando ensilaram o capim-elefante, cultivar Cameron, aos 90 dias de desenvolvimento. Na silagem feita com a forragem emurchecida inteira aos 56 dias de desenvolvimento, 0 resultado encontrado foi próximo ao de Alberto et al. (1993), 44,55 gMS/kg ${ }^{0.75}$, quando ensilaram o capim-elefante, cultivar Cameron, emurchecido aos 75 dias de desenvolvimento, enquanto que nas idades de 70 e 84 dias, o consumo de matéria seca foi inferior.

Embora não tenha havido diferença significativa para idade na avaliação da ingestão de matéria seca pela análise de variância, teste $F$, a análise de regressão identificou a existência de efeito de idade na ingestão de matéria seca, quando se considera o conjunto de silagens sem separá-las por tipo de forragem. A variação da ingestão de matéria seca das silagens pode ser representada por uma curva linear $(P<0,05)$, conforme equação: $y=53,0848$ $0,2792 x$, com $R^{2}=0,9176$. A variação das ingestões de matéria seca é ilustrada na Figura 13.

$\mathrm{Na}$ ilustração da Figura 13, nota-se que o consumo de matéria seca das silagens diminuiu com a maturidade da planta. Esta redução pode ser explicada pelo aumento no teor de ácido acético das silagem feitas com o capim aos 84 dias de desenvolvimento. Wilkins et al. (1971) e Demarquilly (1973) identificaram que as correlações entre consumo e o teor de matéria seca não foram tão altas quanto àquelas entre 0 consumo e 0 teor de 
ácidos voláteis ( tais como o ácido acético). Silveira et al. (1974) não constataram diferença significativa no consumo de matéria seca de silagens de capim-elefante fresco e emurchecido, embora tenha havido uma redução da ingestão de matéria seca com a maturidade da planta.

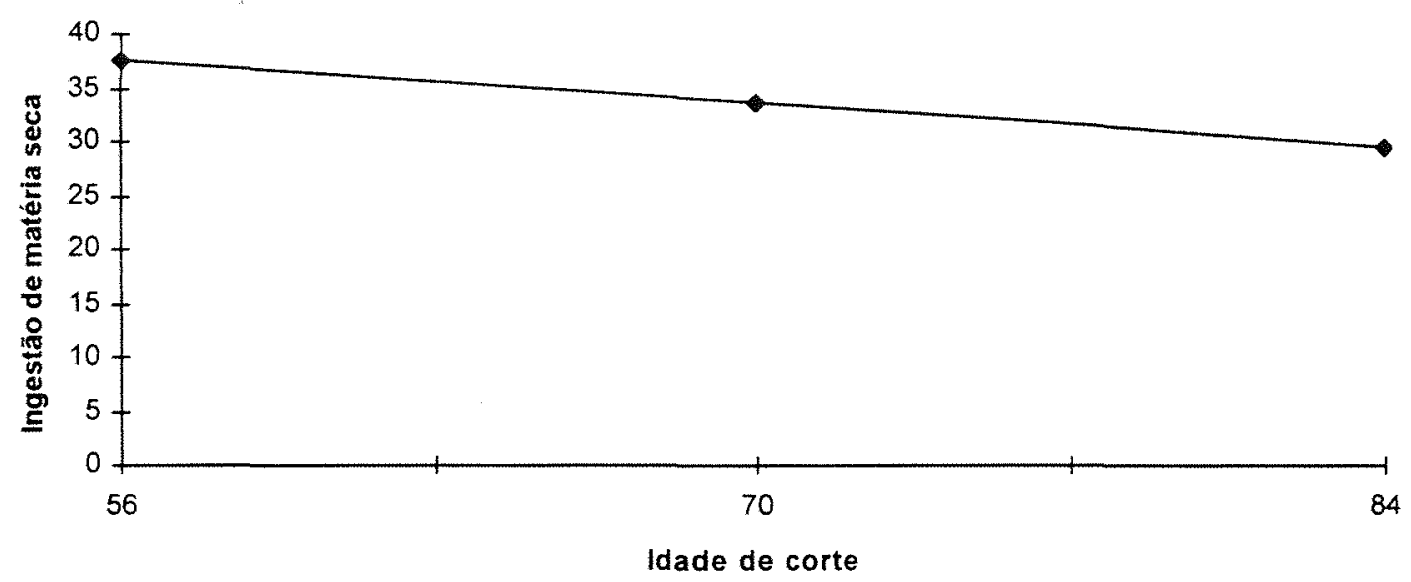

Figura 13. Variação das ingestões de matéria das silagens, em $\mathrm{g} / \mathrm{kg}^{0.75}$, do capim-elefante, cultivar Guaçu, confeccionadas com as forragens fresca e emurchecidas (inteira e triturada), aos 56, 70 e 84 dias de desenvolvimento.

\subsubsection{Coeficiente de digestibilidade aparente da matéria seca}

Os coeficientes de digestibilidade da matéria seca das silagens são apresentados na Tabela 18.

$\mathrm{Na}$ análise de variância dos coeficientes de digestibilidade da matéria seca das silagens, foi observada diferença mínima significativa $(P<0,01)$ para idade, não havendo diferença para tipo de forragem e nem foi 
encontrada interação entre idade e tipo de forragem $(P>0,05)$. $O$ coeficiente de variação encontrado foi de $8,05 \%$.

Tabela 18. Coeficientes de digestibilidade aparente da matéria seca (em \%) das silagens do capim-elefante, cultivar Guaçu, confeccionadas com as forragens fresca e emurchecidas (inteira e triturada), aos 56,70 e 84 dias de desenvolvimento.

\begin{tabular}{ccccc}
\hline & \multicolumn{3}{c}{ Idade de corte } & \multirow{2}{*}{ Média } \\
\cline { 2 - 3 } Tipo de forragem & 56 & 70 & 84 & 56,36 \\
FF $^{1}$ & 59,96 & 58,66 & 50,46 & \\
& & & & 55,93 \\
ET $^{2}$ & 59,13 & 58,81 & 49,84 & \\
\hline Média & 59,60 & 56,56 & 51,48 & 55,88 \\
\hline
\end{tabular}

Forragem fresca', Emurchecida inteira ${ }^{2}$, Emurchecida triturada ${ }^{3}$.

Os resultados encontrados para as silagens feitas com a forragem fresca, nas idades de 56 e 70 dias, foram superiores ao de Andrade (1995), 54,04\%, quando ensilou o capim-elefante, cultivar Guaçu, aos 62 dias de desenvolvimento e ao de Peres (1997), 53,8\%, quando ensilou o capimelefante, cultivar Roxo, aos 72 dias de desenvolvimento. Quanto ao efeito do emurchecimento, os resultados encontrados foram semelhantes aos de Pelletier et al. (1976); Tosi (1978) e Alberto et al. (1993) os quais não observaram diferenças significativas entre a digestibilidade da matéria seca de silagens feitas com forragens fresca e emurchecida de capim-elefante. Por outro lado, são diferentes dos resultados encontrados por Ferreira et al. (1974) e Vilela \& Wilkinson (1987) que constataram diferenças significativas no 
coeficiente de digestibilidade da matéria seca das silagens feitas com as forragens fresca e emurchecida do capim-elefante.

O estudo do efeito de idade, através de análise de regressão, mostrou que a variação dos coeficientes de digestibilidade da matéria seca das silagens confeccionadas com as forragens fresca e emurchecidas (inteira e triturada) do capim-elefante, nas idades, pode ser representada por uma curva linear $(P<0,05)$, conforme equação: $y=78,4802-0,3204 x, \operatorname{com} R^{2}=0,8754 . A$ variação dos coeficientes de digestibilidade é ilustrada na Figura 14.

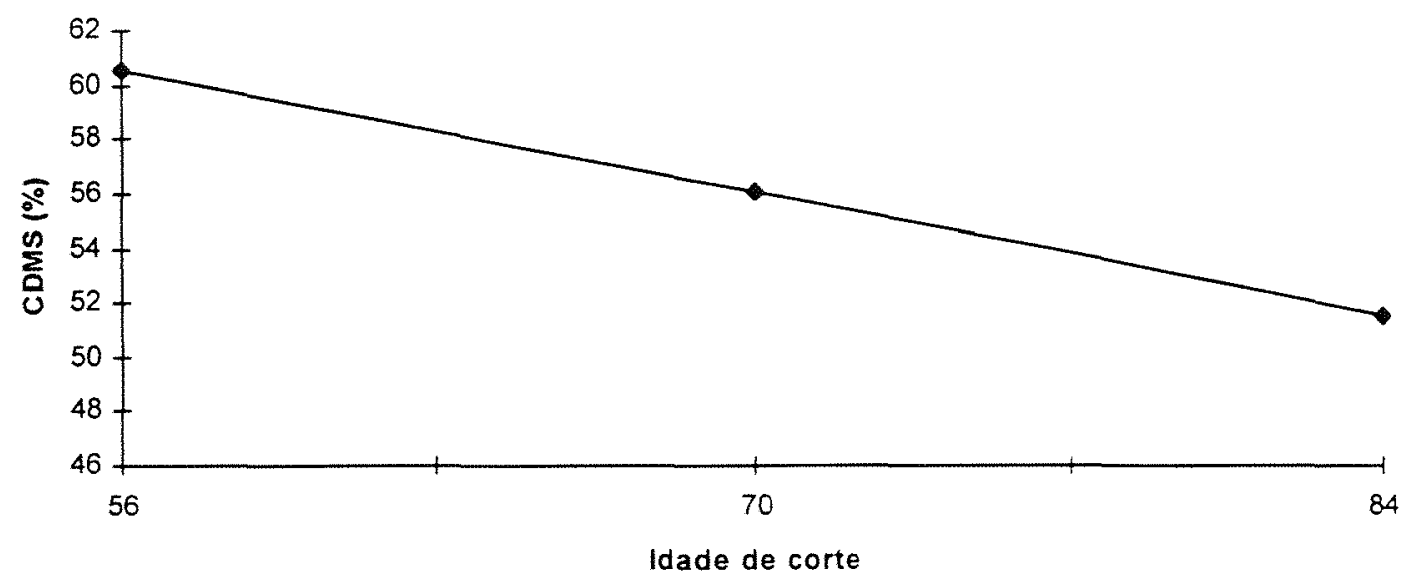

Figura 14. Variação dos coeficientes de digestibilidade da matéria seca das silagens do capim-elefante, cultivar Guaçu, confeccionadas com as forragens fresca e emurchecidas (inteira e triturada), aos 56,70 e 84 dias de desenvolvimento.

$\mathrm{Na}$ ilustração da Figura 14, como era esperado, nota-se que os coeficientes de digestibilidade da matéria seca das silagens independentemente do tipo de forragem diminuiram com a maturidade da planta, confirmando os resultados encontrados por Silveira et al. (1973) quando 
ensilaram o capim-elefante fresco e emurchecido em três estádios de maturidade.

\subsubsection{Coeficiente de digestibilidade aparente da proteína bruta}

Os coeficientes de digestibilidade aparente da proteina bruta das silagens são apresentados na Tabela 19.

$\mathrm{Na}$ análise de variância dos coeficientes de digestibilidade da proteina bruta das silagens, foi observada diferença minima significativa $(P<0,01)$ para idade, não havendo diferença para tipo de forragem e nem foi observada interação entre idade e tipo de forragem $(P>0,05)$. O coeficiente de variação encontrado foi de $13,51 \%$.

Embora não tenha apresentado diferença significativa, o emurchecimento apresentou uma tendência de aumento da digestibilidade da proteína em todos as idades. Alberto et al. (1993) não constataram também diferença significativa entre a silagem feita com o capim-elefante, cultivar Cameron, fresco e a do capim emurchecido. Por outro lado, Ferreira et al. (1974) constataram superioridade da digestibilidade da proteina da silagem feita com a forragem emurchecida quando comparada com a da forragem fresca.

Os resultados encontrados para as silagens feitas com as forragens fresca e emurchecida triturada, na idade de 56 , foram próximos ao de Andrade (1995), 57,03\%, quando ensilou o capim-elefante, cultivar Guaçu, aos 62 dias de desenvolvimento. Por outro lado, com exceção das silagens feitas com as forragens aos 84 dias, os resultados encontrados foram superiores ao de Lima et al. (1972), 48,42\%, quando ensilaram o capim-elefante, cultivar Elefante de Pinda, fresco quando a planta atingia $1,50 \mathrm{~m}$ de altura. Os coeficientes de digestibilidade encontrados, em todas as silagens estudadas, 
foram inferiores ao de Henrique (1990), 68,10\%, quando ensilou o capimelefante, cultivar Guaçu, fresco, aos 63 dias de desenvolvimento.

Tabela 19. Coeficientes de digestibilidade aparente da proteina bruta (em \%) das silagens do capim-elefante, cultivar Guaçu, confeccionadas com as forragens fresca e emurchecidas (inteira e triturada), aos 56,70 e 84 dias de desenvolvimento.

\begin{tabular}{ccccc}
\hline & \multicolumn{3}{c}{ Idade de corte } & \\
\cline { 2 - 4 } Tipo de forragem & 56 & 70 & 84 & Média \\
\hline $\mathrm{FF}^{1}$ & 56,59 & 49,95 & 34,91 & 47,15 \\
$\mathrm{El}^{2}$ & 60,79 & 57,10 & 46,43 & 54,77 \\
$\mathrm{ET}^{3}$ & 58,68 & 53,67 & 44,19 & 52,18 \\
\hline Média & 58,69 & 53,57 & 41,84 & \\
\hline
\end{tabular}

Forragem fresca', Emurchecida inteira ${ }^{2}$, Emurchecida triturada $^{3}$.

O estudo do efeito de idade, através de análise de regressão, mostrou que a variação dos coeficientes de digestibilidade da proteína bruta das silagens confeccionadas com as forragens fresca e emurchecidas (inteira $e$ triturada) do capim-elefante, nas idades, pode ser representada por uma curva linear $(P<0,05)$, conforme equação: $y=93,4726-0,6015 x$, com $R^{2}=0,9511$. A variação dos coeficientes de digestibilidade é ilustrada na Figura 15. 


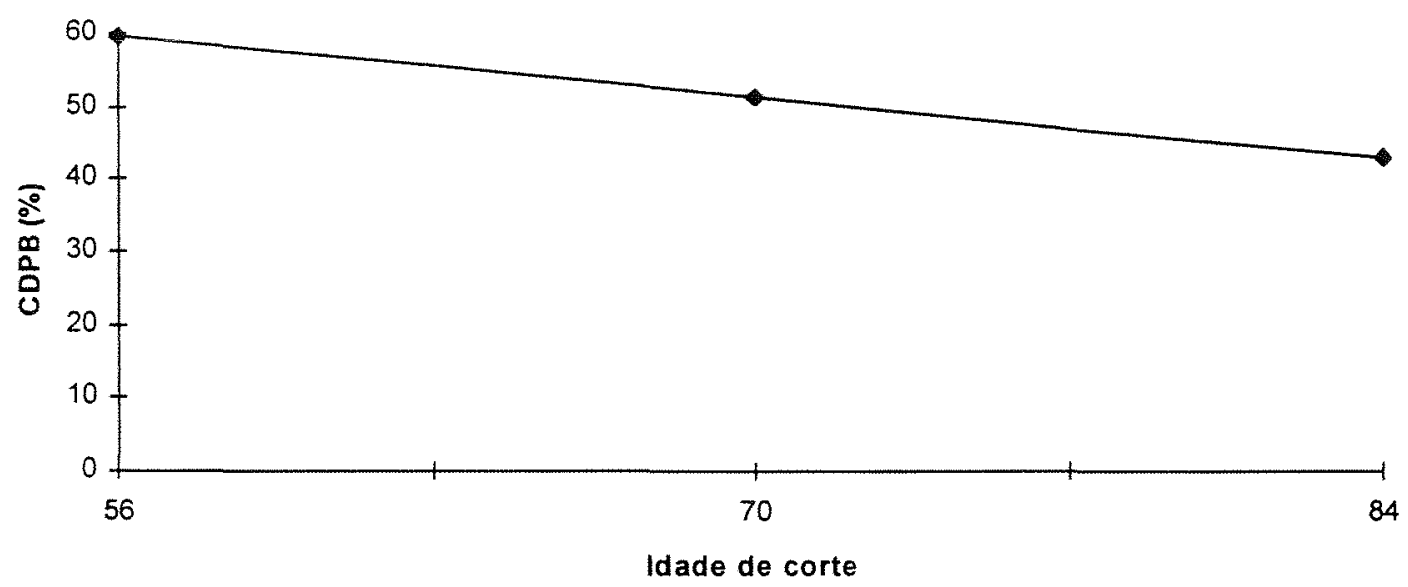

Figura 15. Variação dos coeficientes de digestibilidade aparente da proteina bruta das silagens do capim-elefante, cultivar Guaçu, confeccionadas com as forragens fresca e emurchecidas (inteira e triturada), aos 56,70 e 84 dias de desenvolvimento.

$\mathrm{Na}$ ilustração da Figura 15, nota-se que os coeficientes de digestibilidade da proteina bruta das silagens independentemente do tipo de forragem diminuíram com a maturidade da planta, estando de acordo com os resultados de Ferreira et al. (1974), quando ensilaram o capim-elefante fresco e emurchecido em diferentes estádios de maturidade.

\subsubsection{Coeficiente de digestibilidade aparente da fibra bruta}

Os valores dos coeficientes de digestibilidade da fibra bruta das silagens são apresentados na Tabela 20 .

$\mathrm{Na}$ análise de variância dos coeficientes de digestibilidade da fibra bruta das silagens, foi observada diferença mínima significativa $(P<0,01)$ para idade, não havendo diferença para tipo de forragem e nem foi 
encontrada interação entre idade e tipo de forragem $(P>0,05)$. $O$ coeficiente de variação encontrado foi de $4,79 \%$.

Tabela 20. Coeficientes de digestibilidade aparente da fibra bruta (em \%) das silagens do capim-elefante, cultivar Guaçu, confeccionadas com as forragens fresca e emurchecidas (inteira e triturada), aos 56,70 e 84 dias de desenvolvimento.

\begin{tabular}{ccccc}
\hline & \multicolumn{3}{c}{ Idade de corte } & \multirow{2}{*}{ Média } \\
\cline { 2 - 4 } Tipo de forragem & 56 & 70 & 84 & 65,67 \\
FF $^{1}$ & 67,58 & 68,33 & 61,10 & 63,54 \\
ET $^{2}$ & 66,17 & 65,31 & 59,13 & 63,59 \\
\hline Média & 68,73 & 62,18 & 59,85 & 60,03 \\
\end{tabular}

Forragem fresca', Emurchecida inteira ${ }^{2}$, Emurchecida triturada ${ }^{3}$.

Os resultados encontrados para as silagens feitas com a forragem fresca, nas idades de 56 e 70 dias, foram próximos ao de Andrade (1995), 66,08\% e ao de Henrique (1990), 66,95\%, quando ensilaram o capimelefante fresco, cultivar Guaçu, aos 62 e 63 dias de desenvolvimento, respectivamente, sendo superiores ao de Boin et al. (1968), 63,80\%, quando ensilaram o capim-elefante, cultivar Napier, com 144 a 157 dias de desenvolvimento a partir do plantio. Por outro lado, todos os resultados encontrados foram superiores ao de Peres (1997), 57,0\%, quando ensilou o capim-elefante fresco, cultivar Roxo, aos 72 dias de desenvolvimento e 
inferiores ao de Lima et al. (1972), 69,00\%, quando ensilaram o capim-elefante, cultivar Elefante de Pinda, fresco quando a planta atingia $1,50 \mathrm{~m}$ de altura.

O estudo do efeito de idade, através de análise de regressão, mostrou que a variação dos coeficientes de digestibilidade da fibra bruta das silagens confeccionadas com as forragens fresca e emurchecidas (inteira e triturada) do capim-elefante, nas idades, pode ser representada por uma curva linear $(P<0,05)$, conforme equação: $y=82,9363-0,2667 x$, com $R^{2}=0,9482$. A variação dos coeficientes de digestibilidade é ilustrada na Figura 16.

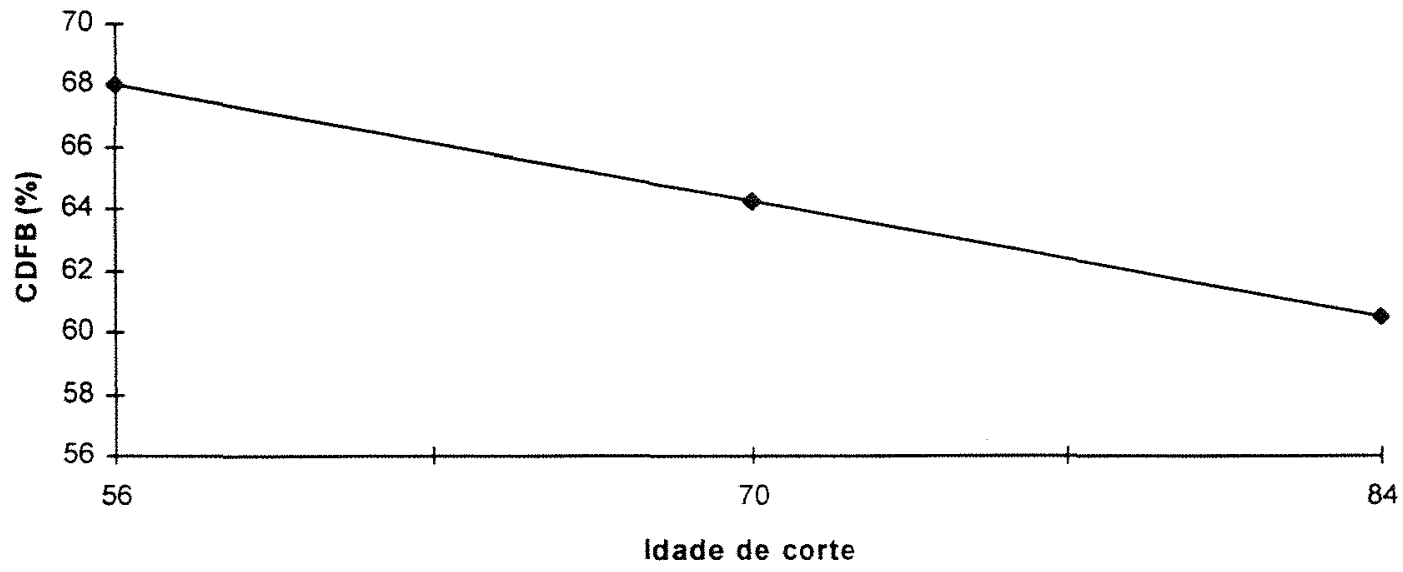

Figura 16. Variação dos coeficientes de digestibilidade da fibra bruta das silagens do capim-elefante, cultivar Guaçu, confeccionadas com as forragens fresca e emurchecidas (inteira e triturada), aos 56,70 e 84 dias de desenvolvimento.

Na ilustração da Figura 16, nota-se que os coeficientes de digestibilidade aparente da fibra bruta das silagens diminuíram com a maturidade da planta. 


\subsubsection{Coeficiente de digestibilidade do extrato etéreo}

Os coeficientes de digestibilidade do extrato etéreo das silagens são apresentados na Tabela 21.

$\mathrm{Na}$ análise de variância dos coeficientes de digestibilidade do extrato etéreo das silagens, foi observada diferença mínima significativa $(P<0,05)$ para idade, não havendo diferença para tipo de forragem e nem foi detectada interação entre idade e tipo de forragem $(P>0,05)$. O coeficiente de variação encontrado foi de $13,66 \%$.

Tabela 21. Coeficientes de digestibilidade do extrato etéreo (em \%) das silagens do capim-elefante, cultivar Guaçu, confeccionadas com as forragens fresca e emurchecidas (inteira e triturada), aos 56 , 70 e 84 dias de desenvolvimento.

\begin{tabular}{ccccc}
\hline & \multicolumn{3}{c}{ Idade de corte } & \\
\cline { 2 - 4 } Tipo de forragem & 56 & 70 & 84 & Média \\
\hline FF $^{1}$ & 76,68 & 74,20 & 52,47 & 67,78 \\
$\mathrm{El}^{2}$ & 73,83 & 72,80 & 66,19 & 70,94 \\
$\mathrm{ET}^{3}$ & 69,72 & 70,49 & 69,09 & 69,77 \\
\hline Média & 73,41 & 72,50 & 62,58 & \\
\hline
\end{tabular}

Forragem fresca', Emurchecida inteira ${ }^{2}$, Emurchecida triturada ${ }^{3}$.

Os resultados encontrados para as silagens feitas com a forragem fresca, nas idades de 56 e 70 dias, foram próximos ao de Andrade (1995), 73,11\%, quando ensilou o capim-elefante, cultivar Guaçu, fresco aos 62 
dias de desenvolvimento. Por outro lado, todos os resultados, com exceção da silagem feita com a forragem fresca aos 84 dias de desenvolvimento, foram superiores ao de Lima et al. (1972), 55,21\%, quando ensilaram o capimelefante, cultivar Elefante de Pinda, fresco, quando a planta atingia $1,50 \mathrm{~m}$ de altura e ao de Peres (1997), 62,5\%, quando ensilou o capim-elefante, cultivar Roxo, fresco aos 72 dias de desenvolvimento. Os coeficientes de digestibilidade encontrados em todas as silagens estudadas foram inferiores ao de Henrique (1990), 82,51\%, quando ensilou o capim-elefante, cultivar Guaçu, fresco aos 63 dias de desenvolvimento.

A avaliação do efeito de idade, através de análise de regressão, mostrou que a variação dos coeficientes de digestibilidade do extrato etéreo das silagens confeccionadas com as forragens fresca e emurchecidas (inteira e triturada) do capim-elefante, nas idades,

pode ser representada por uma curva linear $(P<0,05)$, conforme equação: $y=96,5622-0,3867 x$, com $R^{2}=0,8128$. A variação dos coeficientes de digestibilidade é ilustrada na Figura 17.

Na ilustração da Figura 17, percebe-se que os coeficientes de digestibilidade do extrato etéreo das silagens diminuíram com a maturidade da planta. 


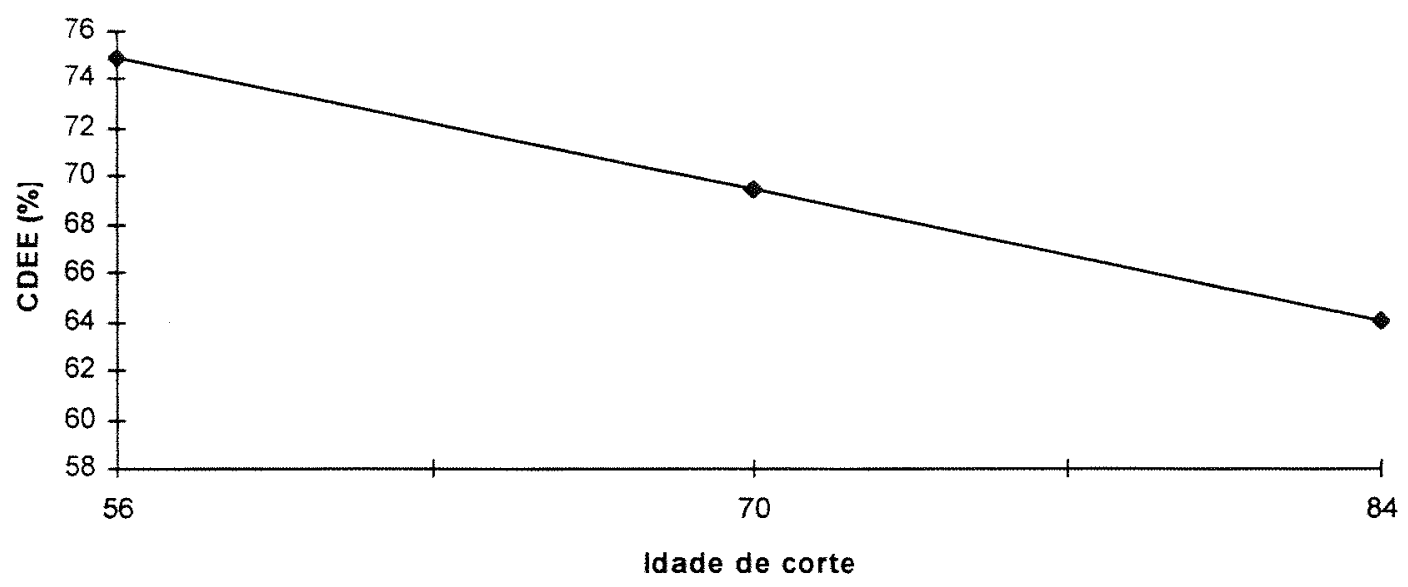

Figura 17. Variação dos coeficientes de digestibilidade do extrato etéreo das silagens do capim-elefante, cultivar Guaçu, confeccionadas com as forragens fresca e emurchecidas (inteira e triturada), aos 56,70 e 84 dias de desenvolvimento.

\subsubsection{Coeficiente de digestibilidade dos extrativos não nitrogenados}

Os coeficientes de digestibilidade dos extrativos não nitrogenados (ENN) das silagens são apresentados na Tabela 22.

$\mathrm{Na}$ análise de variância dos coeficientes de digestibilidade dos extrativos não nitrogenados das silagens, foi observada diferença mínima significativa $(P<0,05)$ para idade, não havendo diferença para tipo de forragem e nem foi observada interação entre idade e tipo de forragem $(P>0,05)$. O coeficiente de variação encontrado foi de $10,32 \%$. 
Tabela 22. Coeficientes de digestibilidade dos extrativos não nitrogenados (em \%) das silagens do capim-elefante, cultivar Guaçu, confeccionadas com as forragens fresca e emurchecidas (inteira e triturada), aos 56,70 e 84 dias de desenvolvimento.

\begin{tabular}{ccccc}
\hline & \multicolumn{3}{c}{ Idade de corte } & \\
\cline { 2 - 4 } Tipo de forragem & 56 & 70 & 84 & Média \\
\hline $\mathrm{FF}^{1}$ & 54,90 & 55,28 & 47,85 & 52,68 \\
$\mathrm{EI}^{2}$ & 54,55 & 54,04 & 44,82 & 51,14 \\
$\mathrm{ET}^{3}$ & 57,65 & 54,02 & 49,16 & 53,61 \\
\hline Média & 55,70 & 54,45 & 47,28 & \\
\hline
\end{tabular}

Forragem fresca', Emurchecida inteira ${ }^{2}$, Emurchecida triturada $^{3}$.

Os resultados encontrados para as silagens feitas com a forragem fresca, nas idade de 56 e 70 dias, foram próximos ao de Lima et al. (1972), 54,87\%, quando ensilaram o capim-elefante, cultivar Elefante de Pinda, fresco, quando a planta atingia $1,50 \mathrm{~m}$ de altura. Por outro lado, estes resultados foram superiores ao de Boin et al. (1968), 53,00\%, quando ensilaram o capim-elefante, cultivar Napier, com 144 a 157 dias de desenvolvimento a partir do plantio; ao de Andrade (1995), 51,97\%, quando ensilou o capim-elefante, cultivar Guaçu, fresco aos 62 dias de desenvolvimento e ao de Peres (1997), 53,1\%, quando ensilou o capimelefante, cultivar Roxo, fresco aos 72 dias de desenvolvimento. Todos os resultados encontrados foram inferiores ao de Henrique (1990), 58,50\%, quando ensilou o capim-elefante, cultivar Guaçu, fresco aos 63 dias de desenvolvimento. 
O estudo do efeito de idade, através de análise de regressão, mostrou que a variação dos coeficientes de digestibilidade dos extrativos não nitrogenados das silagens confeccionadas com as forragens fresca e emurchecidas (inteira e triturada) do capim-elefante, nas idades, pode ser representada por uma curva linear $(P<0,05)$, conforme equação: $y=73,5317$ $0,3008 x$, com $R^{2}=0,8588$. A variação dos coeficientes de digestibilidade é ilustrada na Figura 18.

$\mathrm{Na}$ ilustração da Figura 18, percebe-se que os coeficientes de digestibilidade dos extrativos não nitrogenados das silagens diminuíram com a maturidade da planta.

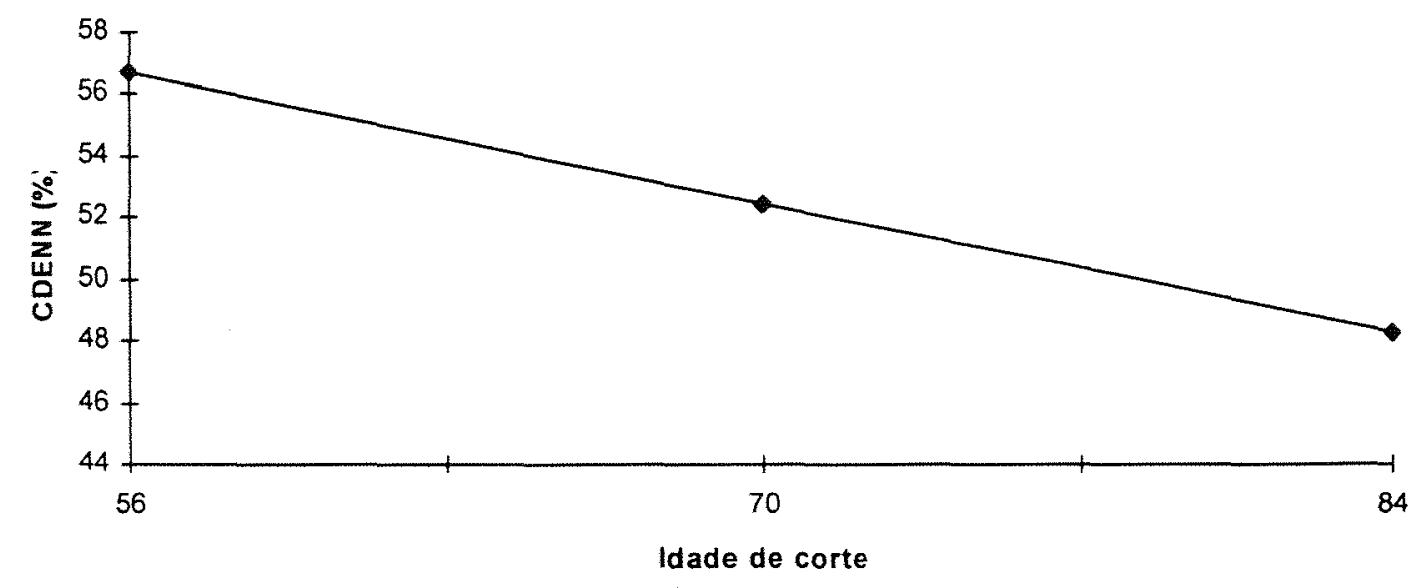

Figura 18. Variação dos coeficientes de digestibilidade dos extrativos não nitrogenados das silagens do capim-elefante, cultivar Guaçu, confeccionadas com as forragens fresca e emurchecidas (inteira e triturada), aos 56,70 e 84 dias de desenvolvimento. 


\subsubsection{Coeficiente de digestibilidade da fibra em detergente neutro}

Os coeficientes de digestibilidade da fibra em detergente neutro (FDN) das silagens são apresentados na Tabela 23.

$\mathrm{Na}$ análise de variância dos coeficientes de digestibilidade da fibra em detergente neutro das silagens, foi observada diferença mínima significativa $(P<0,01)$ para idade, não havendo diferença para tipo de forragem e nem foi encontrada interação entre idade e tipo de forragem $(P>0,05)$. O coeficiente de variação encontrado foi de $7,52 \%$.

Tabela 23. Coeficientes de digestibilidade da fibra em detergente neutro (em \%) das silagens do capim-elefante, cultivar Guaçu, confeccionadas com as forragens fresca e emurchecidas (inteira $e$ triturada), aos 56,70 e 84 dias de desenvolvimento.

\begin{tabular}{ccccc}
\hline & \multicolumn{3}{c}{ Idade de corte } & \multirow{2}{*}{ Média } \\
\cline { 2 - 4 } Tipo de forragem & 56 & 70 & 84 & 60,14 \\
$\mathrm{FF}^{1}$ & 63,03 & 63,68 & 53,70 & \\
$\mathrm{El}^{2}$ & 60,98 & 61,26 & 53,33 & 58,52 \\
$\mathrm{ET}^{3}$ & 63,26 & 58,08 & 53,69 & 58,34 \\
\hline Média & 62,42 & 61,01 & 53,57 & \\
\hline
\end{tabular}

Forragem fresca', Emurchecida inteira ${ }^{2}$, Emurchecida triturada'.

Os resultados encontrados para as silagens feitas com a forragem fresca, nas idades de 56 e 70 dias, foram próximos ao de Henrique (1990), 62,57\%, quando ensilou o capim-elefante, cultivar Guaçu, fresco aos 63 
dias de desenvolvimento e superiores ao de Andrade (1995), 57,62\%, quando ensilou a mesma forrageira aos 62 dias de desenvolvimento. Os resultados encontrados para as silagens feitas com a forragem emurchecida inteira, nestas mesmas idades, foram superiores ao de Lavezzo et al. (1989), 55,77\%, na ensilagem do capim-elefante, cultivar Mineiro, e inferiores aos $62,44 \%$ observados por estes mesmos autores na ensilagem do cultivar Vruckwona, ambos emurchecidos aos 75 dias de desenvolvimento. Todos os resultados encontrados foram superiores ao valor observado por Peres (1997), 52,4\%, quando ensilou o capim-elefante, cultivar Roxo, fresco aos 72 dias de desenvolvimento.

A avaliação do efeito de idade, através de análise de regressão, mostrou que a variação dos coeficientes de digestibilidade da FDN das silagens confeccionadas com as forragens fresca e emurchecidas (inteira e triturada) do capim-elefante, nas idades, pode ser representada por uma curva linear $(P<0,05)$, conforme equação: $y=81,1285-0,3161 x$, com $R^{2}=0,8662 . A$ variação dos coeficientes de digestibilidade é ilustrada na Figura 19.

Na ilustração da Figura 19, percebe-se que os coeficientes de digestibilidade da FDN das silagens independentemente do tipo de forragem diminuiram com a maturidade da planta. 


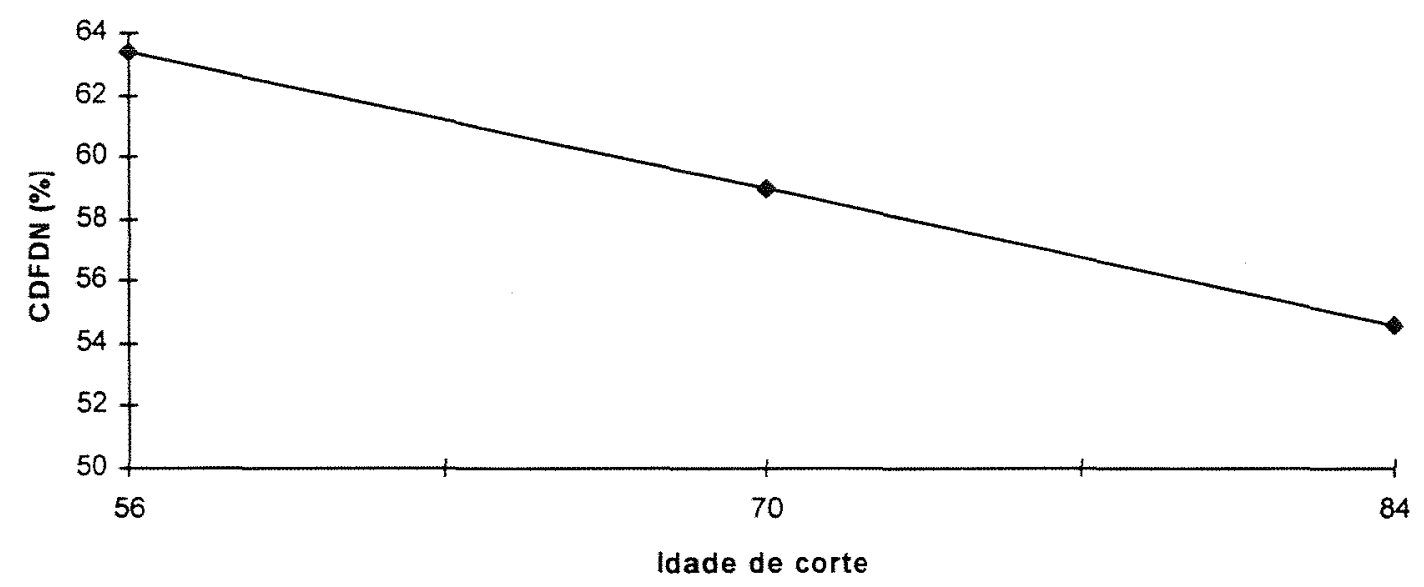

Figura 19. Variação dos coeficientes de digestibilidade da fibra em detergente neutro das silagens do capim-elefante, cultivar Guaçu, confeccionadas com as forragens fresca e emurchecidas (inteira e triturada), aos 56,70 e 84 dias de desenvolvimento.

\subsubsection{Porcentagem de nutrientes digestiveis totais}

As porcentagens de nutrientes digestiveis totais (NDT) na matéria seca das silagens são apresentadas na Tabela 24.

$\mathrm{Na}$ análise de variância dos teores de nutrientes digestíveis totais das silagens, foi observada diferença mínima significativa $(P<0,01)$ para idade, não havendo diferença para tipo de forragem e nem foi detectada interação entre idade e tipo de forragem $(P>0,05)$. $O$ coeficiente de variação dos teores de NDT foi de $7,23 \%$. 
Tabela 24. Porcentagens de nutrientes digestíveis totais na matéria seca das silagens do capim-elefante, cultivar Guaçu, confeccionadas com as forragens fresca e emurchecidas (inteira e triturada), aos $56,70 \mathrm{e}$ 84 dias de desenvolvimento.

\begin{tabular}{ccccc}
\hline & \multicolumn{3}{c}{ Idade de corte } & \multirow{2}{*}{ Média } \\
\cline { 2 - 4 } FF $^{1}$ & 56 & 70 & 84 & 61,13 \\
& 65,31 & 64,36 & 53,71 & \\
El $^{2}$ & 62,86 & 61,66 & 54,03 & 59,52 \\
ET $^{3}$ & 64,42 & 60,73 & 56,30 & 60,48 \\
\hline Média & 64,20 & 62,25 & 54,68 & \\
\hline
\end{tabular}

Forragem fresca', Emurchecida inteira ${ }^{2}$, Emurchecida triturada ${ }^{3}$.

Os valores encontrados para as silagens feitas com a forragem fresca, nas idades de 56 e 70 dias, foram superiores ao de Andrade (1995), $60,55 \%$, quando ensilou o capim-elefante, cultivar Guaçu, fresco aos 62 dias de desenvolvimento; ao de Boin et al. (1968), 55,71\%, quando ensilaram o capim-elefante, cultivar Napier, com 144 a 157 dias de desenvolvimento a partir do plantio e aos de Lavezzo et al. (1989), 58,19\% e 63,68\%, quando ensilaram - capim-elefante, cultivares Mineiro e Vruckwona, respectivamente, emurchecidos. Por outro lado, todos os resultados encontrados foram superiores ao de Lima et al. (1972), 53,15\%, quando ensilaram o capimelefante, cultivar Elefante de Pinda, fresco, quando a planta atingia $1,50 \mathrm{~m}$ de altura e ao de Peres (1997), 52,9\%, quando ensilou o capim-elefante, cultivar Roxo, fresco aos 72 dias de desenvolvimento. 
O estudo do efeito de idade, através de análise de regressão, mostrou que a variação dos teores de NDT das silagens confeccionadas com as forragens fresca e emurchecidas (inteira e triturada) do capim-elefante, nas idades, pode ser representada por uma curva linear $(P<0,05)$, conforme equação: $y=84,1704-0,3399 x$, com $R^{2}=0,8958$. A variação dos teores de NDT é ilustrada na Figura 20.

$\mathrm{Na}$ ilustração da Figura 20, como era esperado, percebe-se que a porcentagem de nutrientes digestíveis totais (NDT) das silagens diminuiu com a maturidade da planta.

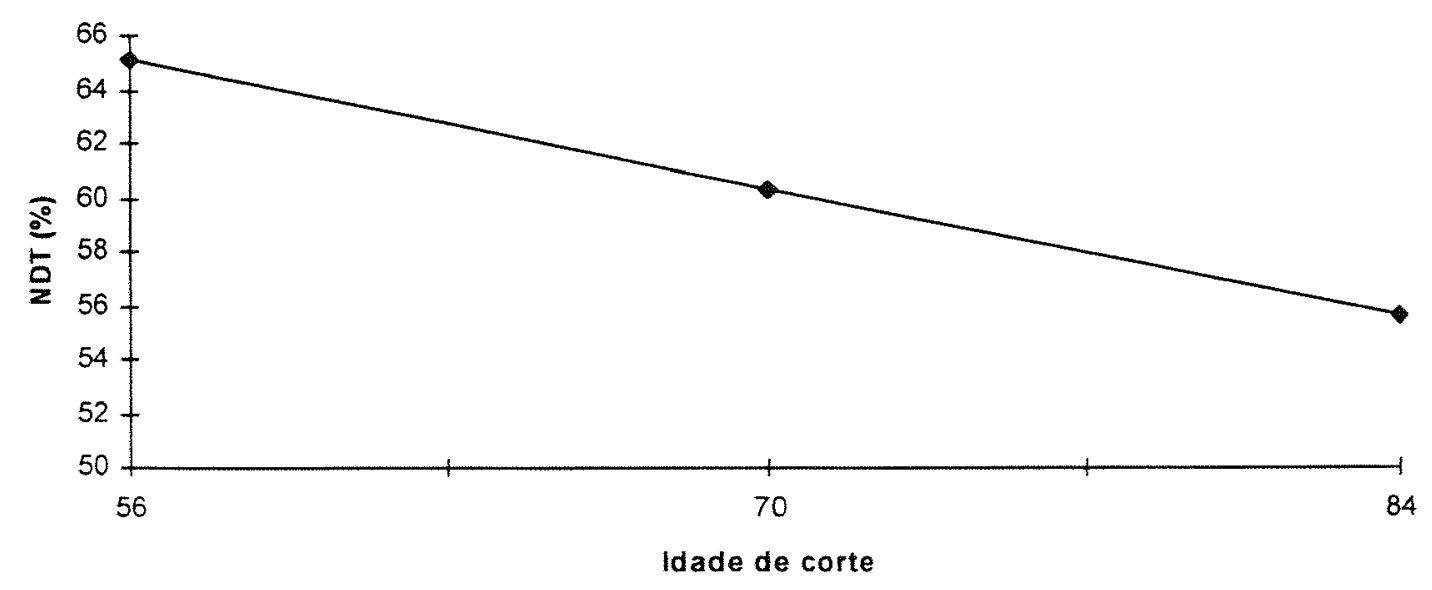

Figura 20. Variação das porcentagens de nutrientes digestiveis totais das silagens do capim-elefante, cultivar Guaçu, confeccionadas com as forragens fresca e emurchecidas (inteira e triturada), aos 56,70 e 84 dias de desenvolvimento. 


\subsubsection{Ingestão de nutrientes digestiveis totais}

Os valores de ingestão de nutrientes digestíveis totais (NDT) das silagens são apresentadas na Tabela 25.

Tabela 25. Valores de ingestão de nutrientes digestiveis totais (em $\mathrm{g} / \mathrm{kg}^{0,75}$ ) das silagens do capim-elefante, cultivar Guaçu, confeccionadas com as forragens fresca e emurchecidas (inteira e triturada), aos 56,70 e 84 dias de desenvolvimento.

\begin{tabular}{ccccc}
\hline & \multicolumn{3}{c}{ Idade de corte } & \multirow{2}{*}{ Média } \\
\cline { 2 - 4 } Tipo de forragem & 56 & 70 & 84 & 17,52 \\
FF $^{1}$ & 22,45 & 16,88 & 13,24 & 22,39 \\
El $^{2}$ & 27,72 & 20,39 & 19,06 & 21,33 \\
\hline Média & 23,20 & 22,70 & 18,09 & \\
\hline
\end{tabular}

Forragem fresca', Emurchecida inteira', Emurchecida triturada ${ }^{3}$.

$\mathrm{Na}$ análise de variância das quantidades de nutrientes digestiveis totais ingeridas das silagens, foi observada diferença mínima significativa $(P<0,05)$ para idade, não havendo diferença para tipos de forragem e nem foi encontrada interação entre idade e tipo de forragem $(P>0,05)$. O coeficiente de variação da quantidade de NDT ingerida foi de $23,42 \%$.

Os valores encontrados foram inferiores ao observado por Henrique (1990), $31,44 \mathrm{~g}$ de NDT/ $\mathrm{kg}^{0,75}$. O resultado obtido para a silagem 
feita com a forragem fresca, na idade de 56 dias, foi superior ao valor de Lima et al. (1972), $0,1445 \mathrm{~kg}$ de NDT/carneiro/dia $\left(19,86 \mathrm{~g} \mathrm{NDT} / \mathrm{kg}^{0,75}\right)$, quando ensilaram o capim-elefante, cultivar Elefante de Pinda, fresco, quando a planta atingia $1,50 \mathrm{~m}$ de altura, sendo inferiores nas idades de 70 e 84 dias.

A avaliação do efeito de idade, através de análise de regressão, mostrou que as ingestões de NDT das silagens confeccionadas com as forragens fresca e emurchecidas (inteira e triturada) do capim-elefante, nas idades, pode ser representada por uma curva linear $(P<0,05)$, conforme equação: $y=39,5620-0,2735 x$, com $R^{2}=0,9909$. A variação da ingestão de NDT é ilustrada na Figura 21.

$\mathrm{Na}$ ilustração da Figura 21, percebe-se que as quantidades ingeridas de nutrientes digestiveis totais (NDT) diminuíram com a maturidade da planta.

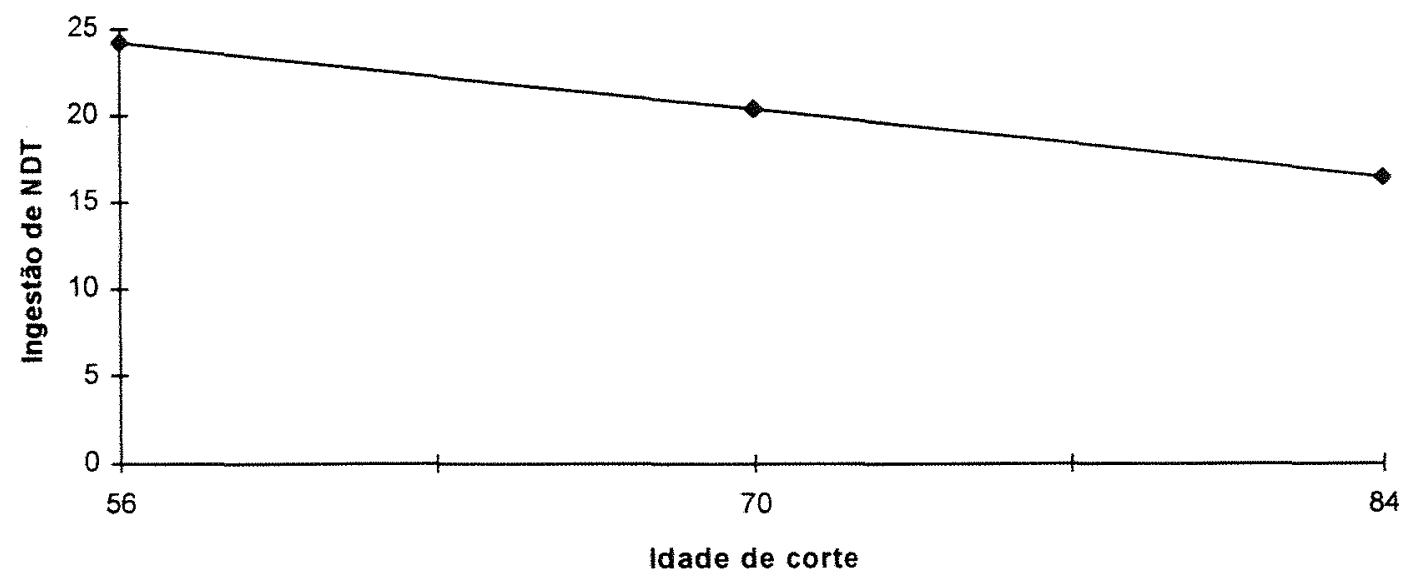

Figura 21. Variação da ingestão de nutrientes digestiveis totais, em $\mathrm{g} / \mathrm{kg}^{0.75}$, das silagens do capim-elefante, cultivar Guaçu, confeccionadas com as forragens fresca e emurchecidas (inteira e triturada), aos 56,70 e 84 dias de desenvolvimento. 


\section{CONCLUSÕES}

A produção de matéria seca cresceu à medida que se aumentou o intervalo de tempo entre o corte de rebaixamento e o corte de aproveitamento da forragem.

A idade de 70 dias foi a que apresentou melhor equilíbrio entre lâmina e haste, aproximando-se mais da relação recomendada pela literatura para ensilagem do capim-elefante.

O emurchecimento foi eficiente na elevação da porcentagem de matéria seca do capim-elefante, cultivar Guaçu, chegando a aumentar mais de dez pontos percentuais.

O período de emurchecimento, deixando a forragem durante 24 horas no campo, não reduziu o teor de carboidratos solúveis a ponto de comprometer a fermentação láctica.

O emurchecimento com a planta triturada não apresentou vantagem em relação ao emurchecimento com a planta inteira, quanto à elevação do teor de matéria seca, sendo sua realização mais trabalhosa.

A prática do emurchecimento não apresentou vantagem qualitativa na ensilagem do capim-elefante, cultivar Guaçu, com teor de matéria seca igual ou superior a $21,20 \%$.

. O consumo voluntário aumentou com o emurchecimento da planta inteira, porém os coeficientes de digestibilidade, a porcentagem de NDT e a ingestão de NDT não foram afetados, podendo-se dispensar esta prática quando o capim-elefante, cultivar Guaçu, estiver com teor de matéria seca igual ou superior a $21,20 \%$. 


\section{REFERÊNCIAS BIBLIOGRÁFICAS}

ALBERTO, G.; PORTELLA, J.S.; OLIVEIRA, O.L.P. de. Efeito da adição de grão de sorgo moído e do emurchecimento sobre a qualidade da silagem de capim-elefante (Pennisetum purpureum Schum.). Revista da Sociedade Brasileira de Zootecnia, v.22, n.1, p.1-11, 1993.

ALVIM, M.A.; BOTREL, M.A.; NOVELLY, P.E. Produção de gramíneas tropicais e temperadas, irrigadas na época da seca. Revista da Sociedade Brasileira de Zootecnia, v.15, n.5, p.384-392, 1986.

ANDRADE, I.F.; GOMIDE, J.A. Curva de crescimento e valor nutritivo do capim-elefante (Pennisetum purpureum Schum.). Revista Ceres, v.18, n.100, p.431-447, Nov. - Dez. 1971.

ANDRADE, J.B. de. Efeito da adição de rolão de milho, farelo de trigo e sacharina na ensilagem do capim-elefante (Pennisetum purpureum Schum.). Botucatu, 1995. 190p. Tese (Doutorado) - Faculdade de Medicina Veterinária e Zootecnia, Universidade Estadual Paulista.

ANDRADE, V.O.; NUCCI, T.A. Silagem. Casa da Agricultura, v.4, n.2, p.18-21, 1982. 
ARIAS, P.J.; BUTTERWORTH, M. Crescimento del pasto elefante. In: INTERNATIONAL GRASSLAND CONGRESS, 9, São Paulo, 1965. Proceedings. São Paulo: Secretaria da Agricultura, 1966. p.407-412.

ASSOCIATION OF OFFICIAL AGRICULTURAL CHEMISTS. Official methods of analysis of the Association of Official Analytical Chemists. 12 ed. Washington, 1975. 1015p.

AZEVEDO, G.P.C. de; ROCHA, G.P.; PINTO, J.C.; et al. Produção e composição química do capim-elefante (Pennisetum purpureum Schum.) "Cameron" em diferentes idades. Ciência e Prática, v.10, n.2, p.169-175, 1986.

BARBOSA, C.L.; MONKS, P.L.; CENTENO, G.A. Produção e qualidade da forragem do capim-elefante (Pennisetum purpureum Schum.), cv. Vruckwona, submetido a diferentes épocas de diferimento e cortes. Ciência Rural, v.25, n. 1, p.115-119, 1995.

BENACCHIO, S. Niveles de melaza en silo experimental de milho criollo (Sorghum vulgare). Agronomia Tropical, v.14, n.4, p.291-297, 1965.

BERTO, J.L.; MÜHLBACH, P.R.F. Silagem de aveia preta no estádio vegetativo, submetida à ação de inoculantes e ao efeito do emurchecimento. Revista Brasileira de Zootecnia, v.26, n.4, p.651-658, 1997.

BOIN, C.; MELOTTI, L.; SCHNEIDER, B.H.; et al. Ensaio de digestibilidade (aparente) de silagem de sorgo, de milho e de capim-elefante - I. Boletim de Indústria Animal, v.25, p.175-195, 1968. 
BRITTO, D.P.P. de S.; ARONOVICH, S.; RIBEIRO, H. Comparação entre 2 variedades de capim-elefante (Pennisetum purpureum Schum.) e de 6 diferentes espaços de tempo entre os cortes das plantas. In: INTERNATIONAL GRASSLAND CONGRESS, 9, São Paulo, 1965. Proceedings. São Paulo: Secretaria da Agricultura, 1966. p.1683-1685.

CANTO, A.C.; TEIXEIRA, L.B.; MEDEIROS, J.C.; et al. Altura do corte em capim-elefante (Pennisetum purpureum Schum.). Seiva, v.34, n.83, p.18-25, 1974.

CARVALHO, L. de. A.; MARTINS, M.S.; SALDANHA, E.M. Bibliografia de Pennisetum purpureum Schum. Brasilia: EMBRAPA-DID, 1982. 380p.

CATCHPOOLE, V.R. Laboratory ensilage of (Setaria aphacelata, cv. Nandi) and (Chloris gayana, cv. Pionear) at a range of dry matter contents. Australian Journal of Experimental Agriculture and Animal Husbandry, v. 12, n.56, p.269-273, 1972.

CATCHPOOLE, V.R.; HENZEL, E.F. Silage and silage-making from tropical herbage species. Herbage Abstracts, v.41, n.3, p.213-221, 1971.

CHENOST, M.; DEMARQUILLY, C. Measurement of herbage intake by housed animals. In: LEAVER, J.D. Herbage intake handbook. Hurley: The British Grassland Society, 1982. p.95-112. 
CORSI, M. Estudo da produtividade e do valor nutritivo do capim-elefante (Pennisetum purpureum Schum.), variedade Napier, submetido a diferentes freqüências e alturas de corte. Piracicaba, 1972. 139p. Tese (Doutorado) Escola Superior de Agricultura "Luiz de Queiroz", Universidade de São Paulo.

DEMARQUILLY, C. Composition chimique, caractéristiques fermentaires, digestibilité et quantité ingérée des ensilages de fourrages: modifications par rapport au fourrage vert initial. Annales de Zootechnie, v.22, n.1, p.1-35, 1973.

DERIAZ, R.E. Routine analysis of carbohydrates and lignin in herbage. Journal Science of the Food and Agriculture, v.12, p. 152-160, Feb. 1961.

De VUYST, A.; VANBELLE, M. Los principios basicos de la conservación de los alimentos por el ensilado. Zootechnia, v.18, n.7/8, p.414-424, 1969.

EVANGELISTA, A.R.; TEIXEIRA, J.C.; BENTO, L.A.; et al. Uso do milho desintegrado com palha e sabugo na forma de aditivo para produção de silagem de capim-elefante (Pennisetum purpureum Schum.). In: REUNIÃO ANUAL DA SOCIEDADE BRASILEIRA DE ZOOTECNIA, 24, Brasilia, 1987. Anais. Brasilia: Sociedade Brasileira de Zootecnia, 1987. p.365.

FARIA, V.P. de. Efeito da maturidade da planta e diferentes tratamentos sobre a ensilagem do capim-elefante (Pennisetum purpureum Schum.) variedade Napier. Piracicaba, 1971. 78p. Tese (Doutorado) - Escola Superior de Agricultura "Luiz de Queiroz", Universidade de São Paulo. 
FARIA, V.P. de. Evolução no uso do capim-elefante: uma visão histórica. In: SIMPÓSIO SOBRE MANEJO DA PASTAGEM, 10, Piracicaba, 1992. Anais. Piracicaba: FEALQ, 1993. p.19-45.

FARIA, V.P. de. Formas de uso do capim-elefante. In: SIMPÓSIO SOBRE CAPIM-ELEFANTE, 2, Juiz de Fora, 1994. Anais. Coronel Pacheco: EMBRAPA-CNPGL, 1994. p.139-148.

FARIAS, 1. Efeito do pré-murchamento e da adição de raspa de mandioca sobre as características da silagem de capim-elefante (Pennisetum purpureum Schum.) cortado em três estádios de desenvolvimento. Viçosa, 1973. 43p. Dissertação (M.S.) - Universidade Federal de Viçosa.

FERREIRA, J.J.; SILVA, J.F.C. da.; GOMIDE, J.A. Efeito do estádio de desenvolvimento, do emurchecimento e da adição de raspa de mandioca sobre o valor nutritivo da silagem de capim-elefante (Pennisetum purpureum Schum.). Experientiae, v.17, n.5, Mar. 1974.

FORBES, T.J.; JACKSON, A. A study of the utilization of silages of different dry-matter content by young beef cattle with or without supplementary barley. Journal of the British Grassland Society, v.26, p.257-264, 1971.

GENNARI, S.M.; MATTOS, H.B. Influência da idade do stand sobre a produção, digestibilidade e composição de três variedades de capimelefante (Pennisetum purpureum Schum.). Boletim de Indústria Animal, v.34, n.2, p.253-262, Jul.-Dez. 1977. 
GHIELFI FILHO, H. Efeito da irrigação sobre a produtividade do capimelefante (Pennisetum purpureum Schum.), variedade Napier. Piracicaba, 1972. 77p. Tese (Doutorado) - Escola Superior de Agricultura "Luiz de Queiroz", Universidade de São Paulo.

GOERING, H.K; VAN SOEST, P.J. Forage fiber analysis. (Apparatus, reagents, procedures, and some applications). Agric. Handb. Forest. Serv., n.379, p.1-20, 1970.

GOMIDE, J.A.; CHRISTMAS, E.P.; GARCIA, R.; et al. Competição de gramíneas forrageiras para corte em um latossolo vermelho distrófico sob vegetação de cerrado do Triângulo Mineiro. Revista da Sociedade Brasileira de Zootecnia, v.3, n.2, p.191-209, 1974.

GORDON, C.H. Storage losses in silage as affected by moisture content and structure. Journal of Dairy Science, v.50, n.3, p.397-403, 1967.

GORDON, C.H.; DERBYSHIRE, J.C.; JACOBSON, W.C.; et al. Effects of dry matter in low-moisture silage on preservation, acceptability, and feeding value for dairy cows. Journal of Dairy Science, v.48, n.7, p.1062-1068, 1965.

GORDON, C.H.; DERBYSHIRE, J.C.; MENEAR, J.R.; et al. Conservation and feed value of low-moisture ochardgrass stored in gas-tight and bunker silos. Journal of Dairy Science, v.50, n.7, p.1109-1115, 1967.

GORDON, C.H.; DERBYSHIRE, J.C.; WISEMAN, H.G.; et al. Preservation and feeding value of alfafa stored as hay, haylage, and direct-cut silage. Journal of Dairy Science, v.44, n.7, p.1299-1311, 1961. 
GRANT, R.J.; VAN SOEST, P.J.; MCDOWELL, R.E. et al. Intake, digestibility and metabolic loss of Napier grass by cattle and buffaloes when fed wilted, chopped and whole. Journal of Animal Science, v.39, n.2, p.423-434, 1974.

GUTIERREZ, L.E. Identificação de carboidratos e ácidos orgânicos em quatro variedades de capim-elefante (Pennisetum purpureum Schum.) colhidas em três estádios de maturidade. Piracicaba, 1975. 103p. Dissertação (M.S.) Escola Superior de Agricultura "Luiz de Queiroz", Universidade de São Paulo.

GUTIERREZ, L.E.; FARIA, V.P. de. Influência da intensidade do murchamento sobre $\circ$ teor de carboidratos solúveis do capim-elefante (Pennisetum purpureum Schum.). O solo, v.68, n.2, p.26-31, 1976.

GUTIERREZ, L.E.; FARIA, V.P. de. Influência da intensidade do murchamento sobre o poder tampão, proteinas e ácidos orgânicos do capim-elefante (Pennisetum purpureum Schum.). 0 solo, v.70, n.2, p.48-52, Jul. - Dez. 1978.

GUTIERREZ, L.E.; FARIA, V.P. de.; SGRINERO, O.; et al. Variações diurnas no teor de carboidratos solúveis de haste e folhas de capim Napier (Pennisetum purpureum Schum.). Anais da Escola Superior de Agricultura "Luiz de Queiroz", v.33, p.267-278, 1976.

HARRIS, C.E.; RAYMOND, W.F. The effect of ensiling on crop digestibility. Journal of the British Grassland Society, v. 18, n.3, p.204-212, 1963. 
HENRIQUE, W. Efeito do uso de aditivos enzimo-bacterianos sobre a qualidade da silagem de capim-elefante (Pennisetum purpureum Schum.). Piracicaba, 1990. 100p. Dissertação (M.S.) - Escola Superior de Agricultura "Luiz de Queiroz", Universidade de São Paulo.

HILLESHEIM, A. Manejo do capim elefante: corte. In: SIMPÓSIO SOBRE MANEJO DA PASTAGEM, 10, Piracicaba, 1992. Anais. Piracicaba: FEALQ, 1993. p.117-141.

JACKSON, N.; FORBES, T.J. The voluntary intake by cattle of four silages differing in dry matter content. Animal production, v.12, p.591-599,1970.

JOHNSON, W.L.; GUERREIRO, J.; PEZO, D. Cell-wall constituents and in vitro digestibility of Napier grass (Pennisetum purpureum). Journal of Animal Science, v.37, n.5, p.1255-1261, 1973.

KNABE, H.O.; WEISE, G. Influence of various factors on the fermentability of grasses. In: INTERNATIONAL GRASSLAND CONGRESS, 12, Moscow, 1974. Proceedings. Moscow, 1974. v.3, p.638-663.

LANCASTER, R.J.; RATTRAY, P.V. Developments in pasture and lucerne silage. New Zealand Journal of Agriculture, v.134, n. 5, p.49-51, 1977.

LANIGAN, G.W.; CATCHPOOLE, V.R. Studies on ensilage. II Plant maturity effects in the ensilage of ryegrass and clover under laboratory conditions. Australian Journal of Agricultural Research, v.13, n.5, p.853-863, 1962. 
LAVEZZO, W. Ensilagem do capim elefante. In: SIMPÓSIO SOBRE MANEJO DA PASTAGEM, 10, Piracicaba, 1992. Anais. Piracicaba: FEALQ, 1993. p.169-275.

LAVEZZO, W.; LAVEZZO, O.E.N.M.; BONASSI, I.A.; BASSO, L.C. Valor nutritivo de silagens de capim-elefante (Pennisetum purpureum Schum.), cultivares Mineiro e Vruckwona, submetidos ao emurchecimento e diferentes aditivos inibidores da fermentação. Revista da Faculdade de Medicina Veterinária e Zootecnia da Universidade de São Paulo, v.26, n.2, p.249-258, 1989.

LAVEZZO, W.; LAVEZZO, O.E.N.M.; BONASSI, I.A.; BASSO, L.C. Efeitos do emurchecimento, formol, ácido fórmico e solução "viher" sobre a qualidade de silagens de capim-elefante, cultivares Mineiro e Vruckwona. Pesquisa Agropecuária Brasileira, v.25, n.1, p.125-134, Jan.1990.

LAVEZZO, W.; LAVEZZO, O.E.N.M.; CAMPOS NETO, O. Efeito do emurchecimento e niveis crescentes de bagaço de cana hidrolisado sobre 0 valor nutritivo das silagens de capim-elefante (Pennisetum purpureum Schum.), cultivar Roxo. In: REUNIÃO DA SOCIEDADE BRASILEIRA DE ZOOTECNIA, 29, Lavras, 1992. Anais. Lavras: Sociedade Brasileira de Zootecnia, 1992. p.62.

LAVEZZO, W.; LAVEZZO, O.E.N.M.; SILVEIRA, A.C.; Efeitos do emurchecimento, formol, e ácido fórmico sobre o consumo e digestibilidade de silagens do capim elefante (Pennisetum purpureum Schum.). Revista da Sociedade Brasileira de Zootecnia, v.13, n.4, p.501-508, 1984. 
LAVEZZO, W.; SILVEIRA, A.C.; TOSI, H.; et al. Parâmetros de avaliação química de silagem de capim-elefante (Pennisetum purpureum Schum.), submetidas ao emurchecimento, formol, ácido fórmico e suas misturas. Revista da Sociedade Brasileira de Zootecnia, v.12, n.4, p.706-719,1983.

LIMA, C.R.; ARAÚJO, M.R.; SOUTO, S.M. Valores nutritivos da silagem de sorgo forrageiro e capins elefante, colonião, pangola e guatemala. Pesquisa Agropecuária Brasileira, Série Zootecnia, v.7, p.53-57, 1972.

LOPES, J.R. da. C.; MONKS, P.L. Qualidade de silagem de capim-elefante (Pennisetum purpureum Schum.), cv. Cameron, submetido a diferentes tratamentos. In: REUNIÄO ANUAL DA SOCIEDADE BRASILEIRA DE ZOOTECNIA, 20, Pelotas, 1983. Anais. Pelotas: Sociedade Brasileira de Zootecnia, 1983. p.365.

MACHADO FILHO, L.C.P.; MÜHLBACH, P.R.F. Efeito do emurchecimento na qualidade das silagens de capim-elefante cv. Cameron (Pennisetum purpureum Schumach.) e de milheto (Pennisetum americanum (L.) Leeke), avaliadas quimicamente. Revista da Sociedade Brasileira de Zootecnia, v. 15, n. $3,1986$.

McCULLOUGH, M.E. Silage and silage fermentação. Feedstuffs, v.49, n.13, p.49-50 e 52, 1977.

McDONALD, P. The biochemistry of silage. New York: John Wiley, 1981. $226 p$. 
MCDONALD, P.; STIRLING, A.C.; HENDERSON, A.R.; et al. Fermentation studies on red clover. Journal of the Science of Food and Agriculture, v. 6, n.9, p.549-557, 1965.

MOORE, L.A.; THOMAS, J.W.; SYKES, J.F. The acceptability of grass/legume silage by dairy cattle. In: INTERNATIONAL GRASSLAND CONGRESS, 8 , 1960. Proceedings. Berkshire, 1960. p.701-704.

MORGAN, C.A.; EDWARDS, R.A.; MCDONALD, P. Intake and metabolism studies with fresh and wilted silages. The Journal of Agricultural Science, v.94, p.287-298, 1980.

NEUMARK, H.; BONDI, A.; VOLCANI, R. Amines, aldehydes and keto-acid in silage and their effect on feed intake by ruminants. Jounal of the Science of Food and Agriculture, v.15, n.7, p.487-492, 1964.

NEUMARK, H.; TADMOR, A. The effect of histamine combined with formic or acetic acid on food intake and rumen motility, when infused into the omasun of a ram. The Journal of Agricultural Science, v.71, p.267-270, 1968.

PEDREIRA, J.V.S.; BOIN, C. Estudo de crescimento do capim-elefante, variedade Napier (Pennisetum purpureum Schum.). Boletim de Indústria Animal, v.26, p.263-273, 1969.

PELLETIER, G.; St-PIERRE, J.C.; COMEAU, J.E. Composition chimique, digestibilité et ingestion voluntairie d'ensilages d'herbes et de mais par des agneaux. Canadian Journal of Animal Science, v.56, n.1, p.65-72, 1976. 
PERES, J.R. Avaliação da polpa de citros seca e peletizada como aditivo na ensilagem do capim-elefante (Pennisetum purpureum Schum.). Piracicaba, 1997. 82p. Dissertação (M.S.) - Escola Superior de Agricultura "Luiz de Queiroz", Universidade de São Paulo.

PINTO, J.C.; GOMIDE, J.A.; MAESTRI, M. Produção de matéria seca e relação folha/caule de gramíneas forrageiras tropicais, cultivadas em vasos, com duas doses de nitrogênio. Revista da Sociedade Brasileira de Zootecnia, v.23, n.3, 1994.

PLAYNE, M.J.; McDONALD, P. The buffering constituints of herbage and of silage. Journal of the Science of Food and Agriculture, v.17, n.6, p.264-268, 1966.

RODRIGUES, L.R.D.; PEDREIRA, J.V.S.; MATTOS, H.B. Adaptação ecológica de algumas plantas forrageiras. Zootecnia, v.13. n.4, p.201-218, 1975.

RODRIGUEZ, S.C.; BLANCO, E. Composición quimica de hojas y tallos de 21 cultivares de elefante (Pennisetum purpureum Schumacher.). Agronomia Tropical, v.20, n.6, p.383-396, 1970.

ROFFLER, R.E.; NIEDERMEIER, R.P.; BAUMGARDT, B.R. Evaluation of alfafa-brome forage stored as wilted silage, low-moisture silage, and hay. Journal of Dairy Science, v.50, n.11, p.1805-1813, 1967.

ROLIN, F.A. Estacionalidade de produção forrageira. In: PEIXOTO, A.M.; MOURA, J.C. de.; FARIA, V.P. de. (Ed.) Pastagens: fundamentos da exploração racional. Piracicaba: FEALQ, 1986. p.243-270. 
RUIZ, T.M.; SANCHEZ, W.K.; STAPLES, C.R. Comparison of "Mott" Dwarf Elephantgrass silage and corn silage for lactating dairy cows. Journal Dairy Science, v.75, p.533-543, 1992.

SANTANA, J.R.; PEREIRA, J.M.; ARRUDA, N.G. de.; et al. Avaliação de cultivares de capim-elefante (Pennisetum purpureum Schum.) no Sul da Bahia. I. Agrossistema Cacaueiro. Revista da Sociedade Brasileira de Zootecnia, v.18, n.3, p.273-283, 1989.

SILVEIRA, A.C. Efeito da maturidade da planta e diferentes tratamentos sobre a digestibilidade "in vitro" de silagens de capim-elefante, variedade Napier (Pennisetum purpureum Schum.). Piracicaba, 1970. 98p. Dissertação (M.S.) - Escola Superior de Agricultura "Luiz de Queiroz", Universidade de São Paulo.

SILVEIRA, A.C. Técnicas para produção de silagens. In: SIMPÓSIO SOBRE MANEJO DA PASTAGEM, 2, Piracicaba, 1975. Anais. Piracicaba: ESALQ, 1975. p.156-180.

SILVEIRA, A.C.; LAVEZZO, W.; SILVEIRA FILHO, S.; et al. Consumo de silagens capim-elefante (Pennisetum purpureum Schum.) submetidas a diferentes tratamentos. Revista da Sociedade Brasileira de Zootecnia, v.9, n.2, p.306-320,1980.

SILVEIRA, A.C.; LAVEZZO, W.; TOSI, H.; et al. Avaliação química de silagens de capim-elefante (Pennisetum purpureum Schum.) submetidas a diferentes tratamentos. Revista da Sociedade Brasileira de Zootecnia, v.8, n.2, p.287-300, 1979. 
SILVEIRA, A.C.; TOSI, H.; FARIA, V.P. de. Efeito da maturidade sobre a composição química bromatológica do capim Napier (Pennisetum purpureum Schum.). Revista da Sociedade Brasileira de Zootecnia, v.3, n.2, p.158-171, 1974.

SILVEIRA, A.C.; TOSI, H.; FARIA, V.P. de.; et al. Efeito de diferentes tratamentos na digestibilidade "in vitro" de silagem de capim Napier (Pennisetum purpureum Schum.). Revista da Sociedade Brasileira de Zootecnia, v.2, n.2, p.216-226, 1973.

SMITH, L.H. Theoretical carboydrate requirement for alfafa silage production. Agronomy Journal, v.54, n.4, p.291-293, 1962.

SPAIN, G.L.; SANTIAGO, J.V. Napier grass harvest readiness. The Journal of Agriculture of the University of Puerto Rico, v.57, n.4, p.300-306, 1973.

STAPLES, G.E.; DINUSSON, W.E. A comparison of the relative accuracy between seven-day and ten-day collection periods in digestion trials. Journal of Animal Science, v.10, n.1, p.244-250, 1951.

TCACENCO, F.A.; BOTREL, M.A. Identificação e avaliação de acessos e cultivares de capim-elefante. In: CARVALHO, M.M.; ALVIM, M.J.; XAVIER, D.F.; et al. (Ed.) Capim-elefante: produção e utilização. Coronel Pacheco: EMBRAPA-CNPGL, 1994. p.1-30.

THOMAS, J.W.; MOORE, L.A.; OKAMOTO, M.; et al. A study of factors affecting rate of intake of heifers fed silage. Journal of Dairy Science, v.44, n.8, p.1471-1483, 1961. 
TOSI, H. Ensilagem de gramíneas tropicais sob diferentes tratamentos. Botucatu, 1973. 107p. Tese (Doutorado) - Faculdade de Ciências Médicas e Biológicas, Universidade Estadual Paulista.

TOSI, H. Avaliação do capim-elefante (Pennisetum purpureum Schum.), cultivar Taiwan A-148, conservado nas formas de silagem e feno. Jaboticabal, 1978. 92p. Tese (L.D.) - FCAV, Universidade Estadual Paulista.

TOSI, H.; BONASSI, I.A.; ITURRINO, R.P.S.; et al. Avaliação química e microbiológica da silagem de capim-elefante, cultivar Taiwan A-148, preparada com bagaço de cana-de-açúcar. Pesquisa Agropecuária Brasileira, v.24, n.11, p.1313-1317, Nov. 1989.

TOSI, H.; BONASSI, I.A.; SILVEIRA, A.C.; et al. Avaliação química de silagens de capim-elefante cultivar Taiwan A-148. Pesquisa Agropecuária Brasileira, v.18, n.1, p.67-72, Jan. 1983a.

TOSI, H.; FARIA, V.P. de; GUTIERREZ, L.E.; et al. Avaliação do capimelefante, cultivar Taiwan A-148, como planta para ensilagem. Pesquisa Agropecuária Brasileira, v.18, n.3, p.295-299, Mar. 1983b.

TOSI, H.; RODRIGUES, L.R. de A.; JOBIM, C.C.; et al. Ensilagem do capimelefante, cv. Mott, sob diferentes tratamentos. Revista da Sociedade Brasileira de Zootecnia, v. 24, n.6, p.909-916,1995.

TOTH, L.; RYDIN, C.; NILSSON, R. Studies on fermentation processes in silage. Comparison of different types of forage crops. Archiv für Mikrobiologie, v.25, p.208-218, 1956. 
VILELA, D. Utilização do capim-elefante na forma de forragem conservada. In: CARVALHO, M.M.; ALVIM, M.J.; XAVIER, D.F.; et al. (Ed.) Capim-elefante: produção e utilização. Coronel Pacheco: EMBRAPA-CNPGL, 1994. p.117-164.

VILELA, D.; DAYRELL, M. de S.; CRUZ, G.M. Efeito da altura de corte do capim-elefante (Pennisetum purpureum Schum.) e de diferentes tratamentos sobre a produção e qualidade da silagem. Coronel Pacheco: EMBRAPA-CNPGL, 1981. p.83-88. (Relatório Técnico Anual do Centro Nacional de Pesquisa de Gado de Leite, 1980).

VILELA, D.; SILVA, J.F.C. da.; GOMIDE, A.J.; et al. Digestibilidade aparente dos nutrientes das silagens de capim-elefante (Pennisetum purpureum Schum.) com diferentes teores de matéria seca e níveis de uréia. Revista da Sociedade Brasileira de Zootecnia, v.19, n.3, p.162-180, 1990.

VILELA, D; WILKINSON, J.M. Efeito do emurchecimento e da adição da uréia sobre a fermentação e digestibilidade "in vitro" do capim-elefante (Pennisetum purpureum Schum.) ensilado. Revista da Sociedade Brasileira de Zootecnia, v.16, n.6, p.550-562, 1987.

WEIBBACH, H.F.; SCHIMIDT, L.; HEIN, E. Method of antecipation of the run of fermentation in silage making, based on the chemical composition of green fodder. In: INTERNATIONAL GRASSLAND CONGRESS, 12, Moscow, 1974. Proceedings. Moscow, 1974. v.3, p.663-672.

WHITTENBURY, R.; MCDONALD, P.; BRYAN-JONES, D.G. A short review of some biochemical and microbiological aspects of ensilage. Journal of the Science of Food and Agriculture, v. 18, p.441-444, Oct. 1967. 
WIERINGA, G.W. The effect of wilting on butiric acid fermentation in silage. Netherlands Journal of Agricultural Science, v.6, n.3, p.204-210, 1958.

WIERINGA, G.W. Some factors affecting silage fermentation. In: INTERNATIONAL GRASSLAND CONGRESS, 8, Berkshire, 1960. Proceedings. Berkshire, 1960. p.497-502.

WIERINGA, G.W. The influence of nitrate on silage fermentation. In: INTERNATIONAL GRASSLAND CONGRESS, 10, Helsinki, 1966. Proceedings. Helsinki, 1966. p.537-540.

WILKINS, R.J.; HUTCHINSON, K.J.; WILSON, R.F.; et al. The voluntary intake of silage by sheep. I. Interrelationships between silage composition and intake. The Journal of Agricultural Science, v.77, p.531-537, 1971.

WILKINS, R.J.; WILSON, R.F. Silage, fermentation and feed value. Journal of the British Grassland Society, v. 26, n.2, p.108, 1970.

WILKINSON, J.M. Valor alimenticio de las forrajeras ensiladas de clima tropical y templado. Revista Mundial de Zootecnia, v.46, p.35-40, 1983.

WILKINSON, J.M.; CHAPMAN, P.F.; WILKINS, R.J.; et al. Interrelationships between patern of fermentation during ensilage and initial crop composition. In: INTERNATIONAL GRASSLAND CONGRESS, 14, Lexington, 1981. Proceedings. Boulder: Westview Press, 1982. p.631-634.

WILKINSON, J.M.; WILSON, R.F.; BARRY, T.N. Factors affecting the nutritive value of silage. Outlock on Agriculture, v.9, n.1, p.3-8, 1976. 
WILSON, R.K. A rapid accurate method for measuring volatile fatty acids and latic acid in silage. Dublin: Agricultural Institute, 1971. $7 p$.

YEO, Y. Efeito da maturidade do capim-elefante (Pennisetum purpureum Schum.), variedade Napier, sobre a sua produção e o seu valor nutritivo. Piracicaba, 1977. 96p. Dissertação (M.S.) - Escola Superior de Agricultura "Luiz de Queiroz", Universidade de São Paulo.

ZUÑIGA, M.P.; SYKES, D.J.; GOMIDE, J.A. Competição de treze gramíneas forrageiras para corte, com e sem adubação, em Viçosa. Revista Ceres, v.13, n.77, p.324-343, 1967. 